Supplement of The Cryosphere, 12, 577-594, 2018 https://doi.org/10.5194/tc-12-577-2018-supplement (C) Author(s) 2018. This work is distributed under the Creative Commons Attribution 3.0 License.

(c) (1)

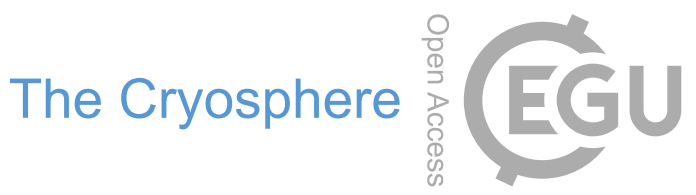

Supplement of

\title{
Changes in glacier dynamics in the northern Antarctic Peninsula since 1985
}

Thorsten Seehaus et al.

Correspondence to: Thorsten Seehaus (thorsten.seehaus@fau.de)

The copyright of individual parts of the supplement might differ from the CC BY 3.0 License. 
Overview:

Section S1: Velocity change measurements

\section{Figures:}

Figure S1-S74: Temporal changes in glacier area and flow speed - median values of measurements along the terminus profiles

Figure S75-S148: Temporal changes in glacier area and flow speed - measured at maximum ice thickness at the terminus profiles

Figure S149-S156: Surface velocity across the terminus and respective median values of Drygalski, TPE61, Bagshawe-Grubb, Bleriot, DGC14, Russell West, Temple and TPE8 glaciers

Figure S157-S160: Velocity fields obtained from ERS, ENVISAT, ALOS PALSAR and TerraSAR/TanDEM-X data

Figure S161: Categorizations of glaciers based on the temporal variations of area changes and flow velocities - measured at maximum ice thickness at the terminus profiles

Figure S162: Spatial distribution of glacier types along the west coast - cluster analysis based on velocity measurements at maximum ice thickness at the terminus profiles

Figure S163: Boxplots of cluster analysis - velocity measurements at maximum ice thickness at the terminus profiles

Figure S164: Dendrogram of hierarchical cluster analysis - velocity measurements at maximum ice thickness at the terminus profiles

Tables:

Table S1: Observed parameters of the individual glaciers - median velocity measurements along terminus profiles

Table S2: Observed parameter of the individual glaciers - velocities measured at maximum ice thickness at terminus profiles

Table S3: Uncertainties of intensity tracking results 


\section{S1: Velocity change measurements}

Two approaches to measure and analyze the temporal changes in flow velocities of the studied glaciers are evaluated. For the first approach, the flow velocities are extracted at across glacier profiles, defined for each basin close to the terminus, considering the maximum frontal retreat state (see Fig. 1 in the manuscript), and the median values along the profiles are then calculated (see also Section 3.2 in the manuscript). For the second approach, the flow velocities are measured at the location of maximum ice thickness at the respective across glacier terminus profile (same as for the first approach). The ice thickness information is taken from the Huss and Farinotti (2014) ice thickness reconstruction dataset of the Antarctic Peninsula. The temporal evolution of the ice velocities of all observed glaciers is plotted in Fig. S1-S74 (for the first approach) and Fig. S75-S148 (for the second approach).

For the first approach, velocity profiles with partial profile coverage (for glaciers located at the border of a velocity field) or large data gaps are sorted out. Data voids usually occur towards the lateral parts of the glacier (e.g. regions affected by SAR shadow, caused by the valley side walls), whereas the maximum ice thickness is usually found towards the center of the terminus. Therefore, some more velocity measurements are obtained using the second approach (2256 measurements for the first approach; 2736 measurements for the second approach; see Table S1 and S2).

The temporal changes in the flow speed of all studied glaciers are categorized according to Table 3 (manuscript) for both approaches (see Table S1 and S2). The same categories are used for 50 glaciers (68\%) by both approaches. Taking the first approach as a reference, the largest mismatch (9 glaciers) between both approaches is found for the category "stable". However, most of these "mismatched" glaciers are categorized as "fluctuating" glaciers, using measurements obtained by the second approach (note: this mismatch does not influence the subsequent cluster analysis since both velocity change categories have the same numerical rating, see manuscript Section 3.4 and Table 3). For both approaches, the same threshold of $0.25 \mathrm{~m} / \mathrm{d}$ for the temporal variability of the measurements is applied for the category "stable" in order to carry out a comparable analysis. However, the comparison of Fig. S1-S74 and S75-S148 shows that the magnitude of the temporal variability of the flow speed is typically higher for the second approach, since the values obtained using the first approach are smoothed by averaging along the profiles.

Small differences in the mean velocity change rate ( $d v$ in \%) in the observation period are found for Sector "East" (-58.0\% for the first approach, $-69 \%$ for the second approach) and "West" (+41.3\% for the first approach, $+44.5 \%$ for the second approach). At sector "EastIS", an average increase in flow speed by $+26.5 \%$ for the first approach and $+41.0 \%$ for the second approach is obtained. This divergence can be explained by the different forcing at sector "EastIS". The glaciers were buttressed by the Larsen-A and Prince Gustav ice shelves until they broke up in 1995. The subsequent acceleration of the glaciers led to changes in the across glacier velocity profiles (see Fig. S149). The highest acceleration is found towards the center of the glacier terminus (where usually the ice thickness is the greatest). Thus, the change in glacier type from ice shelf terminating to tide water glaciers differently affects both velocity measuring methods and leads to the observed deviations. However, a general acceleration is revealed by both approaches.

The impact of the velocity measuring approach on the cluster analysis (Section 3.4, manuscript) is small. The results of the cluster analysis (boxplots, dendrogram and the spatial distribution of the glacier groups) using the first velocity measuring approach are presented in the manuscript and the results using the second velocity measuring approach are shown in Fig. S162-S164. Most of the glaciers, 42 out of 48, are assorted to equal groups. Compared to the grouping based on the first velocity measuring approach, group 2 lost 6 glaciers using the second velocity measuring approach. Two glaciers are attributed to group 1 and four glaciers to group 3 . Hence, these glaciers are only assorted to neighboring groups, which have the greatest similarity to the original group.

To sum it up, both velocity measuring approaches reveal comparable results at our study region. The results of both approaches are provided in this supplement to facilitate a better comparison with results from other studies. As discussed above, the shape of the across glacier velocity profiles can change over time and the peak position as well (see Fig. S149-S156). Moreover, the maximum ice thickness does not necessarily overlap with the peak in the velocity profiles, since estimates of the former also have significant uncertainties. These cases can impact on the observed temporal evolution of the flow speed using a fixed position to measure the velocities, as performed by applying the second velocity measuring approach (at maximum ice thickness at the terminus profile) or by other studies using manually defined measuring positions. Therefore, we decided to use the results of the first approach for the detailed analysis and discussion in the manuscript since it takes into account the changes in flow speed across the whole glacier terminus and, in our opinion, this method is more representative for the changes in ice dynamics and ice discharge of a glacier system. 
Fig.: S1 ADD ID: 2707 Glacier

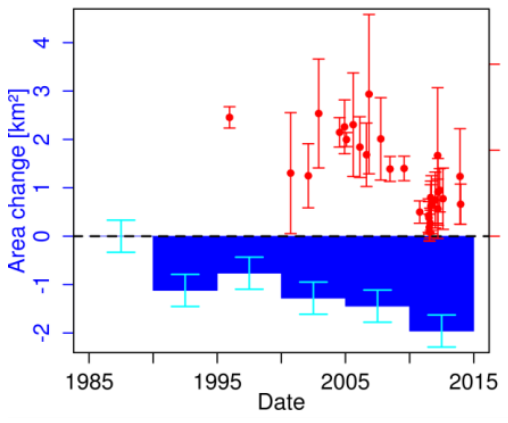

Fig.: S4 Broad Valley Glacier

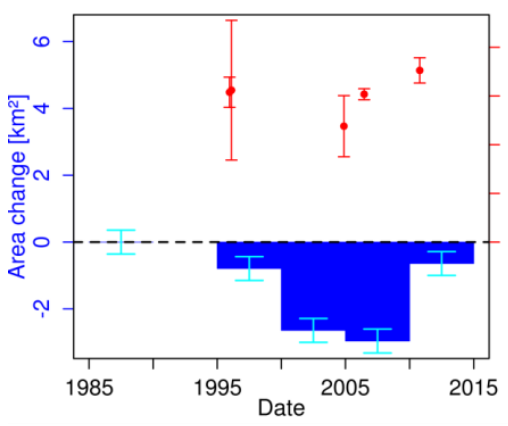

Fig.: S7 Russell East Glacier

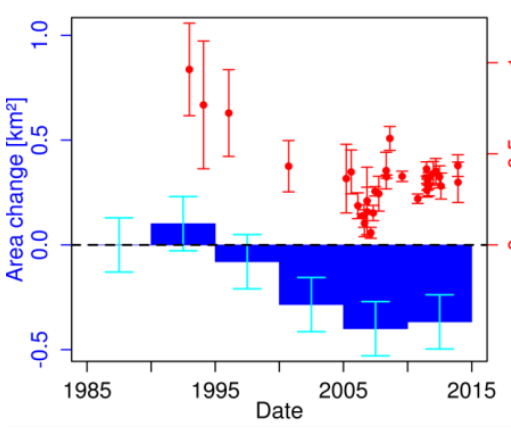

Fig.: S10

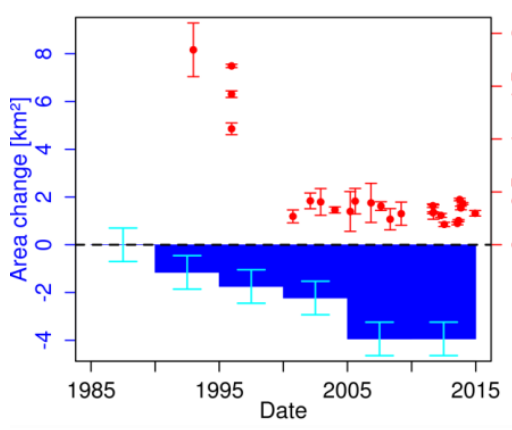

Fig.: S13 Victory Glacier

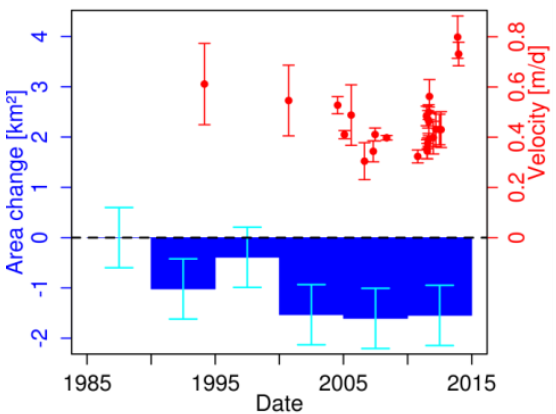

Figure S1-S13. Temporal changes of surface velocity (median values of measurements along terminus profiles) (red) and area (blue) changes of glaciers in sector "East".

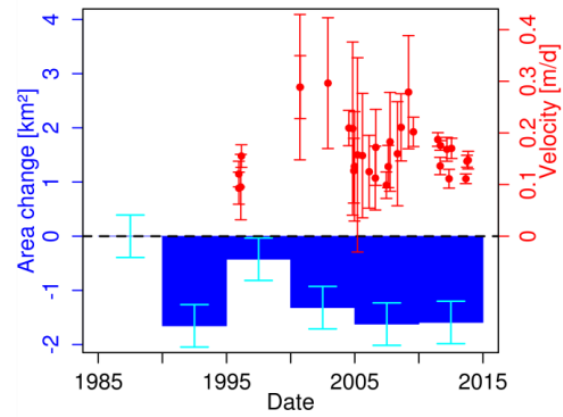

Fig.: S6 Eyrie Glacier

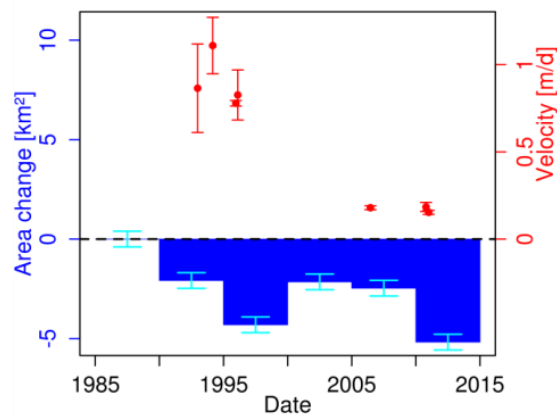

Fig.: S9 TPE130 Glacier
Fig.: S3 Aitkenhead Glacier
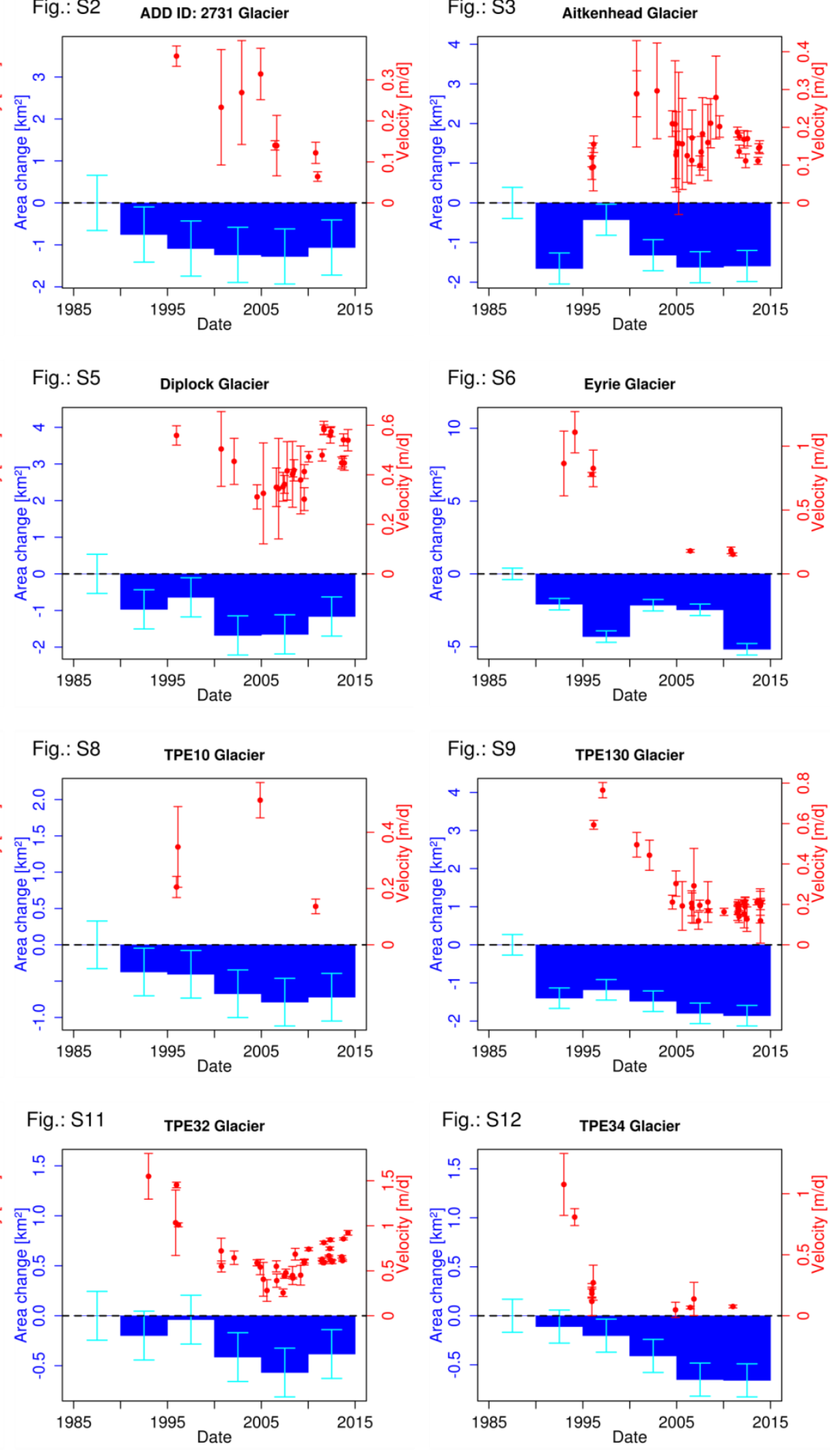

(1) 
Fig.: S14 ADD ID: 2558 Glacier

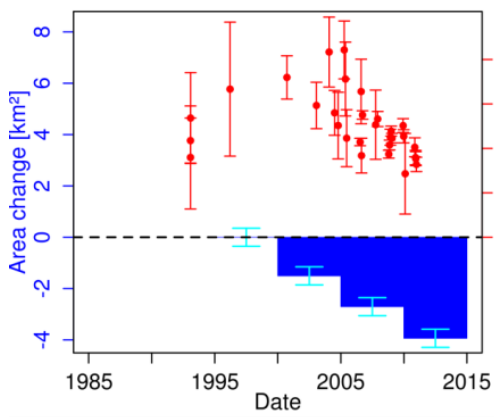

Fig.: S17 Arron Icefall Glacier

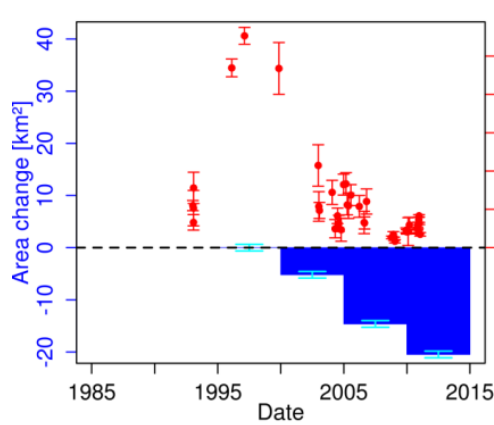

Fig.: S20 Drygalski Glacier

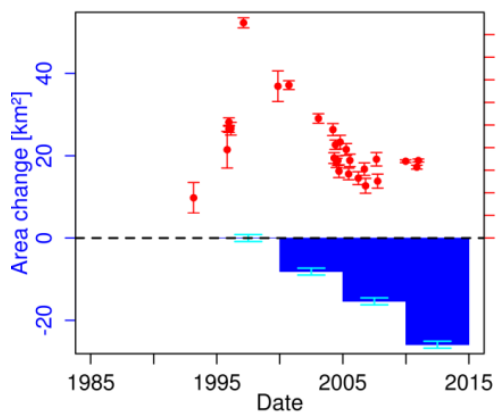

Fig.: S23

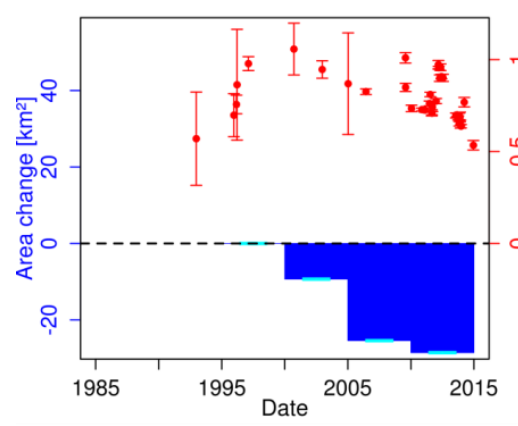

Fig.: S26

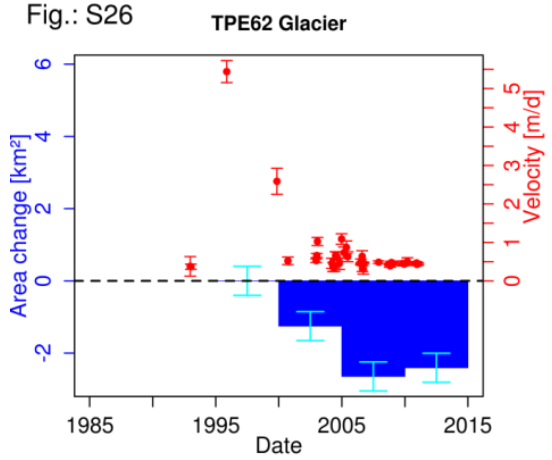

Figure S14-S26. Temporal changes of surface velocity (median values of measurements along terminus profiles)

(red) and area (blue) changes of glaciers in sector "East-Ice-Shelf".
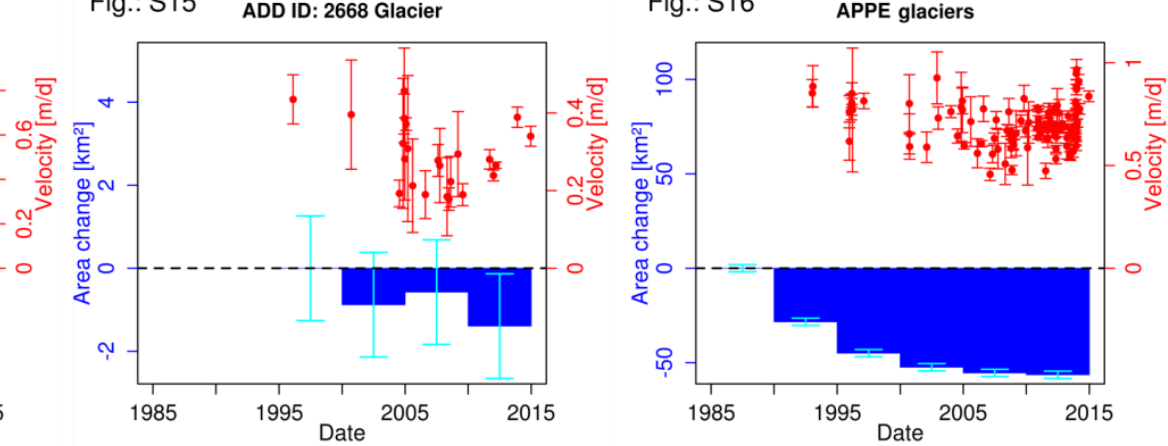

Fig.: S18 Boydell Glacier

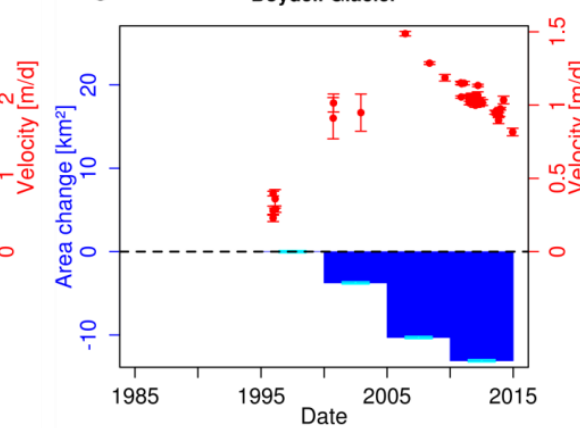

Fig.: S19 DBE glaciers

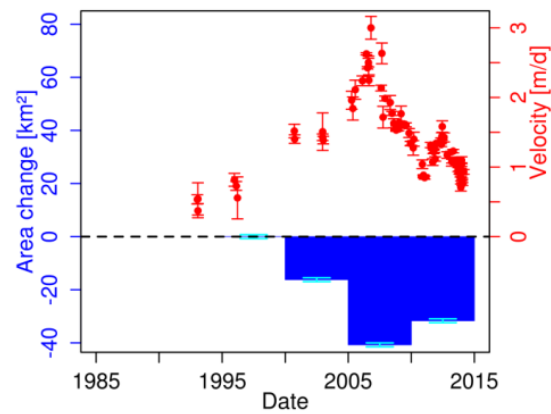

Fig.: S21

LAB2 Glacier

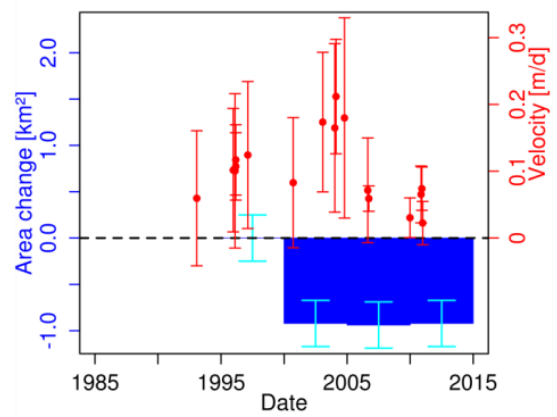

Fig.: S22 LAB32 Glacier

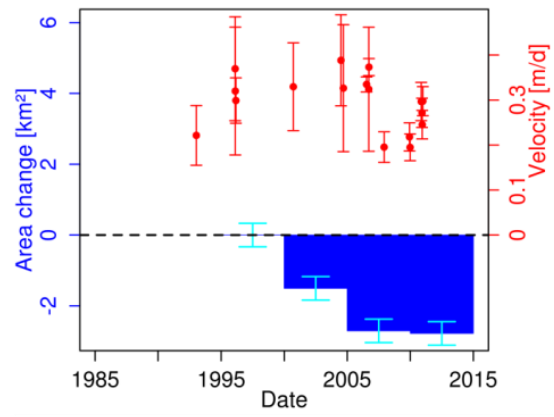

Fig.: S24 TPE114 Glacier
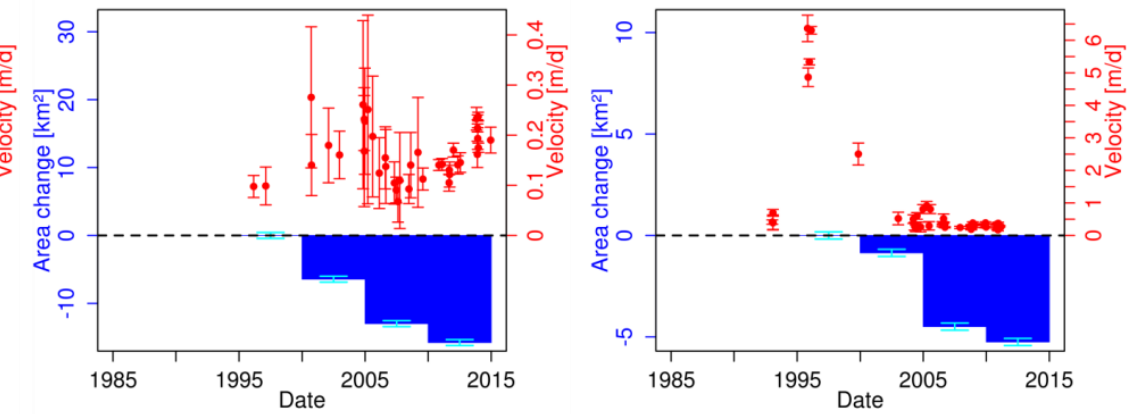

Fig.: S16 APPE glaciers

Fig.: S25 TPE61 Glacier 
Fig.: S27

AMR glaciers

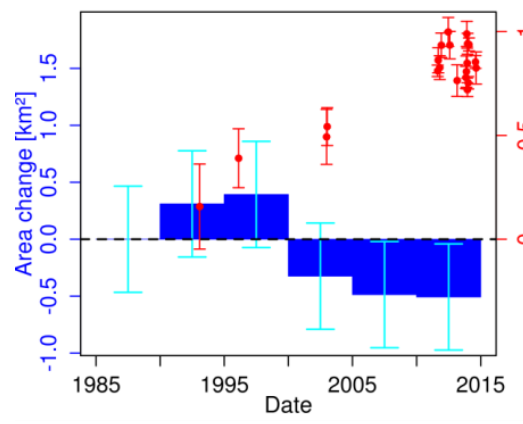

Fig.: $\mathrm{S30}$

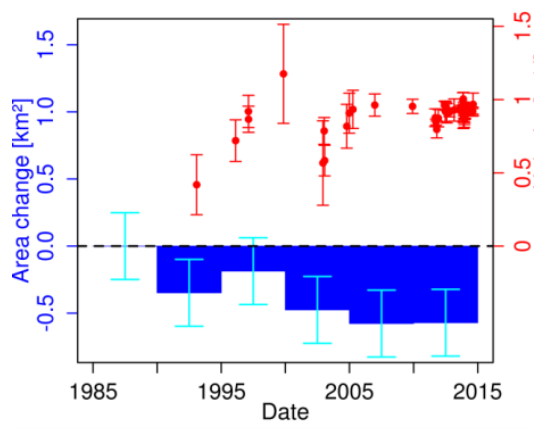

Fig.: S33

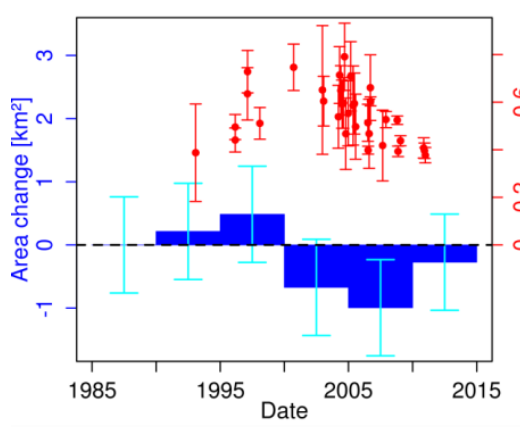

Fig.: S36 DGC13 Glacier

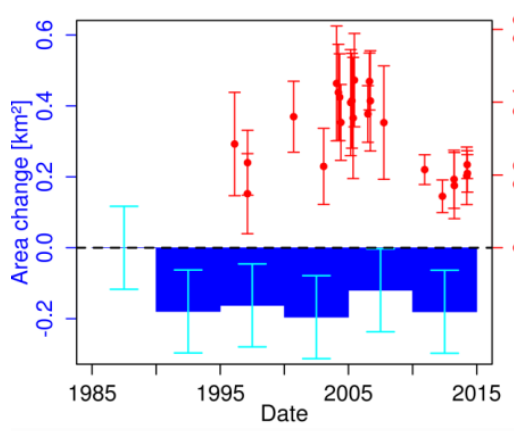

Fig.: S39 DGC23 Glacier

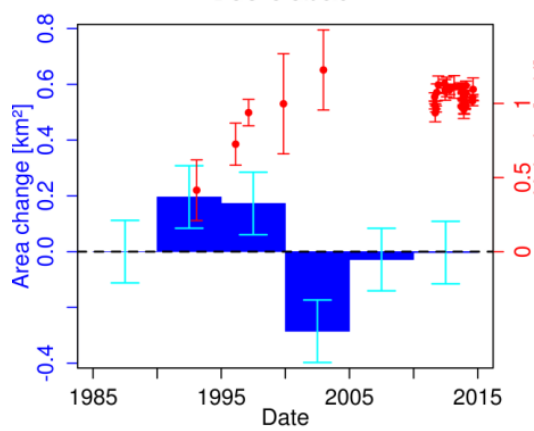

Fig.: S28

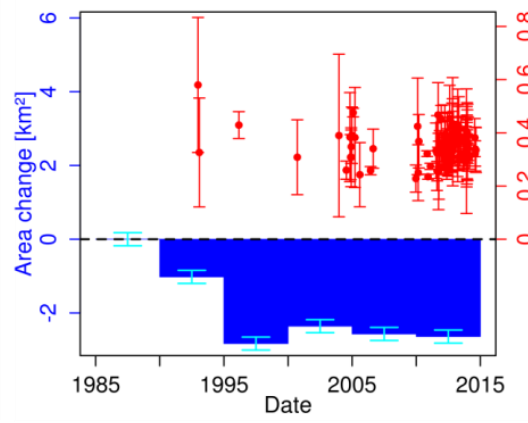

Fig.: S31 Blanchard Glacier

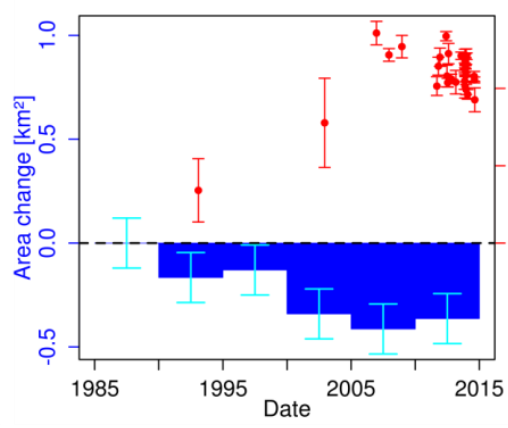

Fig.: S34

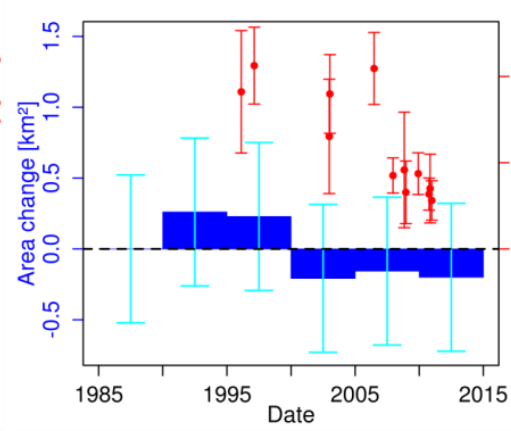

Fig.: S37

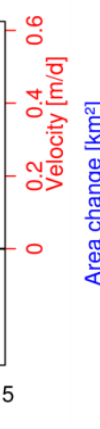

Fig.: S29 Bagshawe-Grubb glaciers

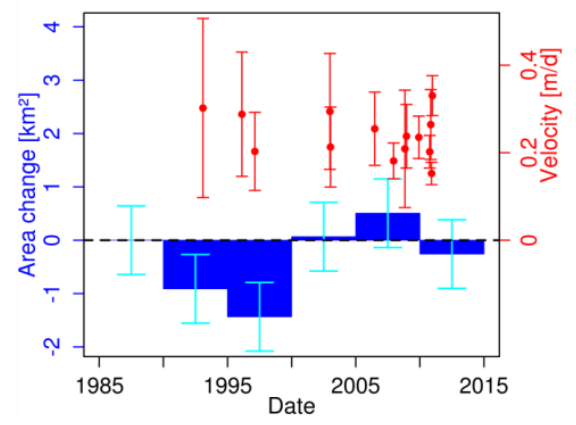

Fig.: S32 Bleriot Glacier

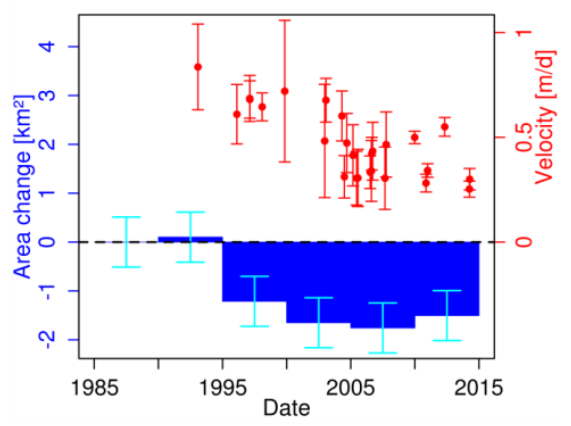

Fig.: S35 DGC10 Glacier

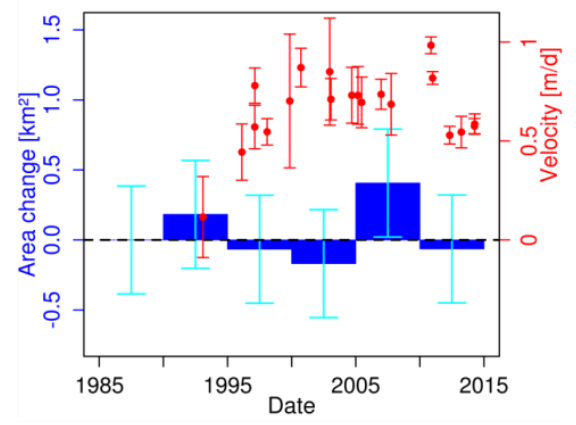

Fig.: S38 DGC22 Glacier

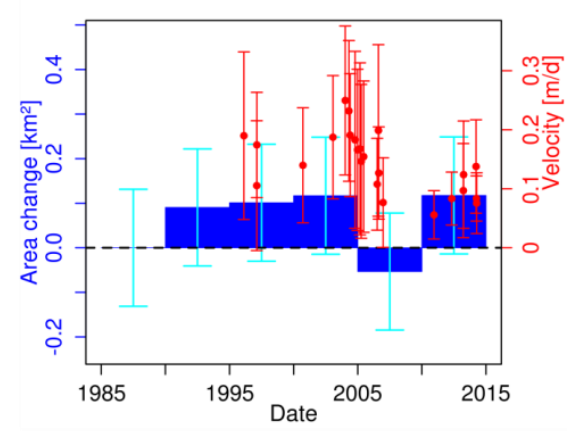

Fig.: S41 DGC31 Glacier

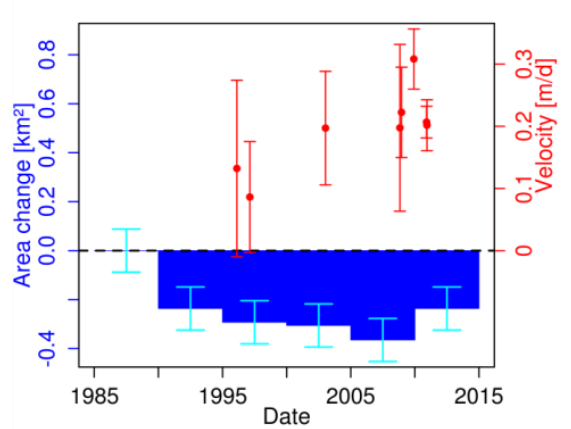

Figure S27-S41. Temporal changes of surface velocity (median values of measurements along terminus profiles) (red) and area (blue) changes of glaciers in sector "West". 
Fig.: S42

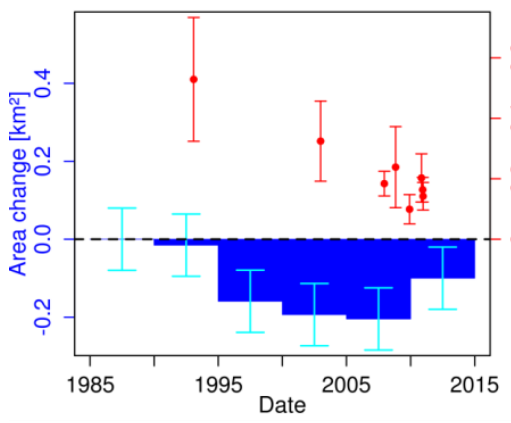

Fig.: S45

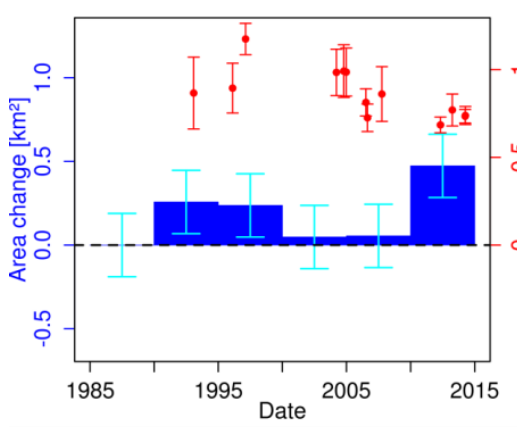

Fig.: S48 Mc Neile Glacier

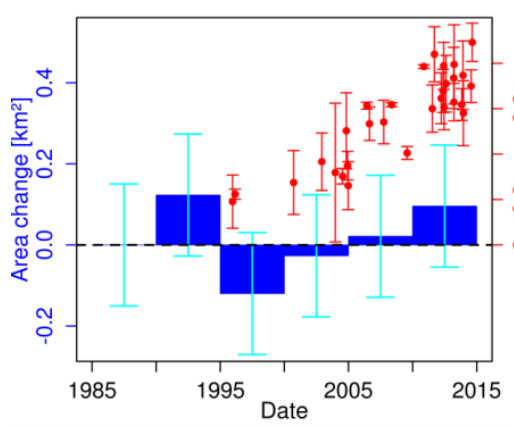

Fig.: S51

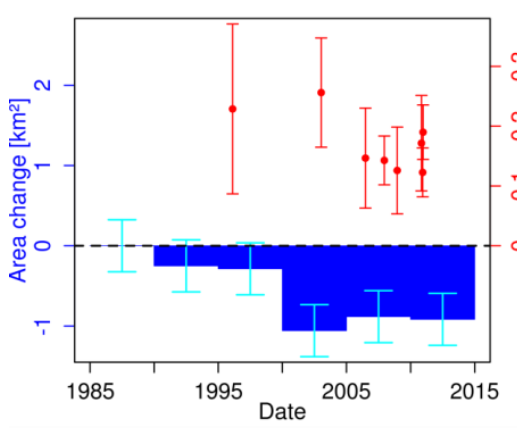

Fig.: S54 Rozier Glacier

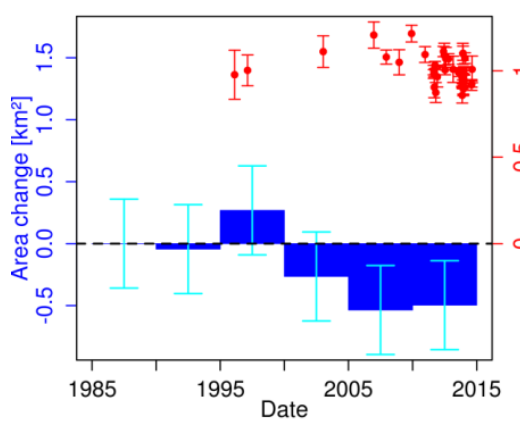

Fig.: S43

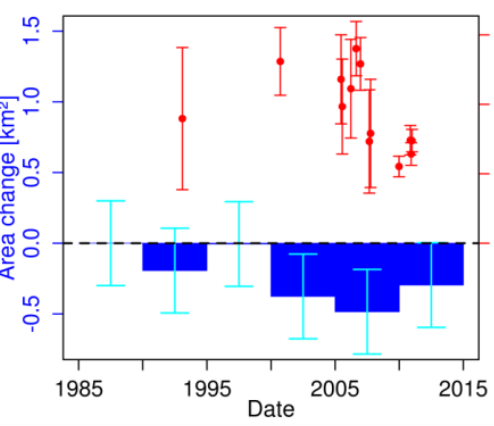

Fig.: S46

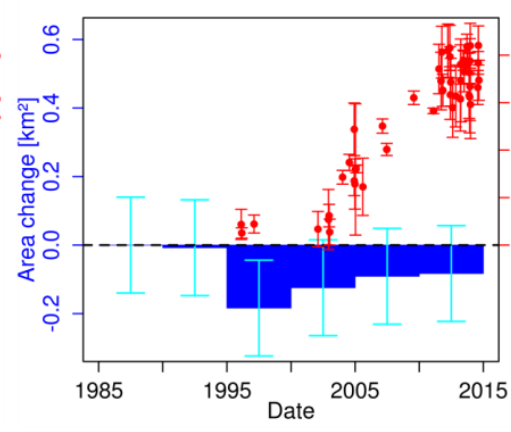

Fig.: S49 Montgolfier Glacier

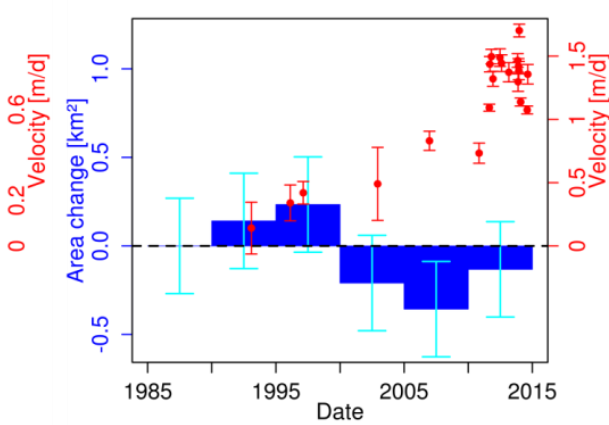

Fig.: S52 Pettus-Gavinlce glaciers

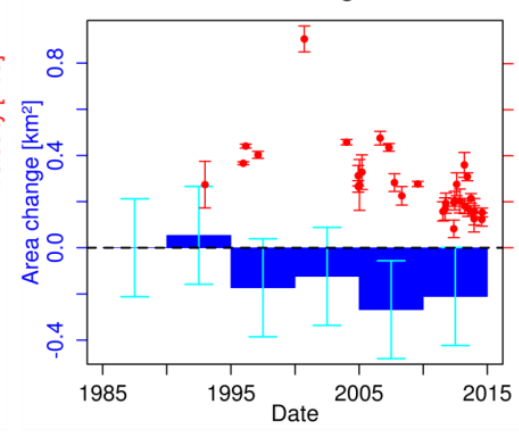

Fig.: S55 Russell West Glacier

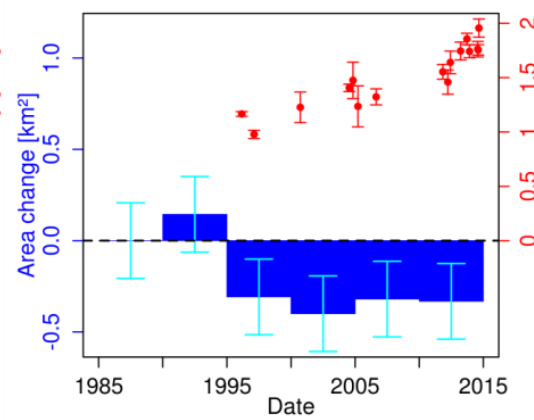

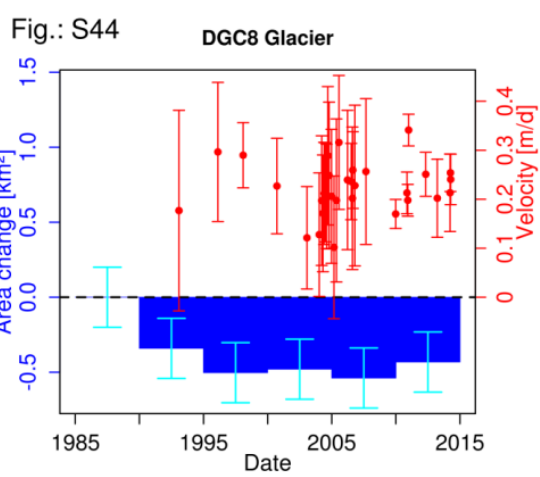

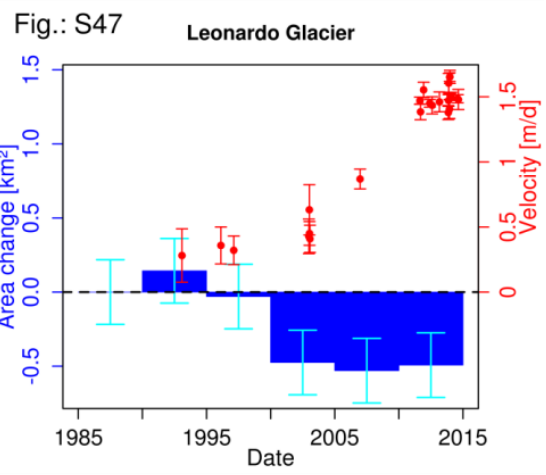

Fig.: S50 Nobile Glacier
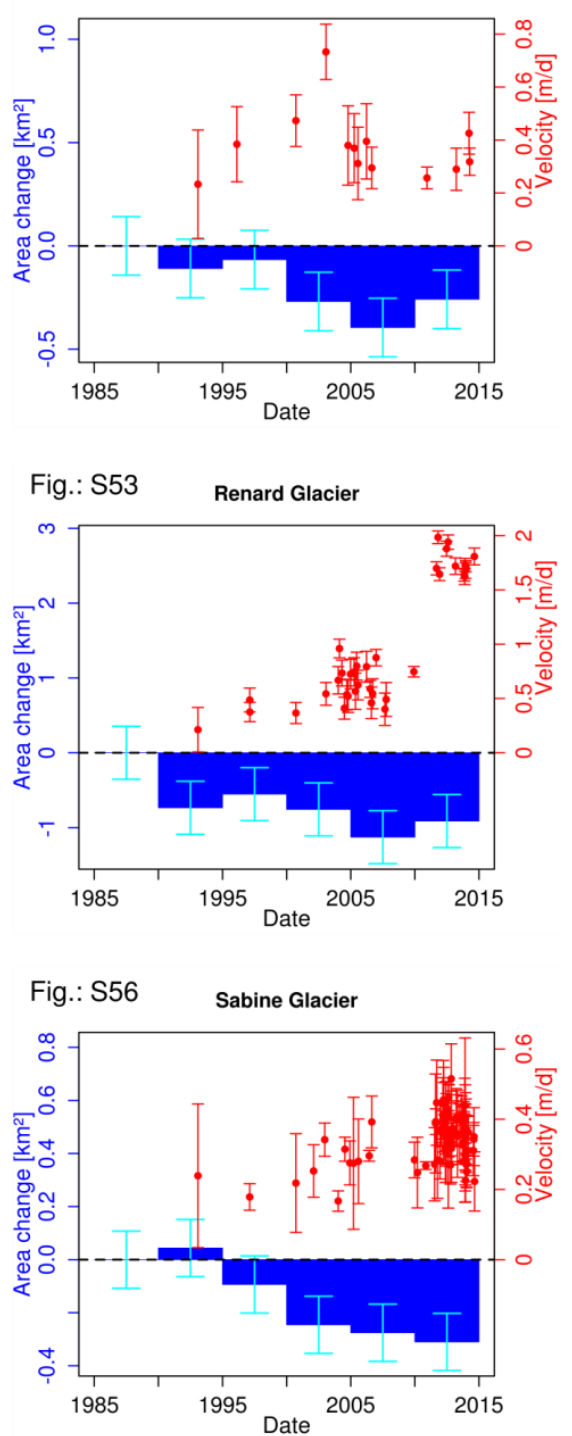

Figure S42-S56. Temporal changes of surface velocity (median values of measurements along terminus profiles) (red) and area (blue) changes of glaciers in sector "West". 
Fig.: S57

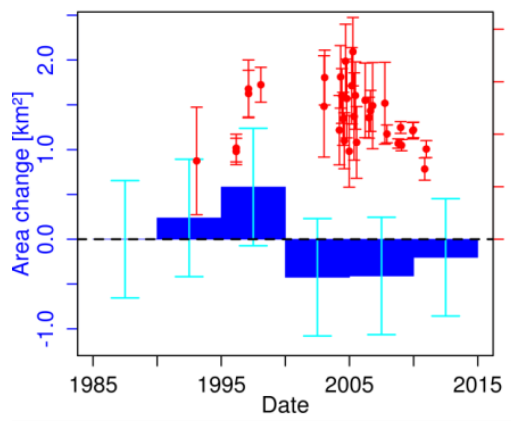

Fig.: S60

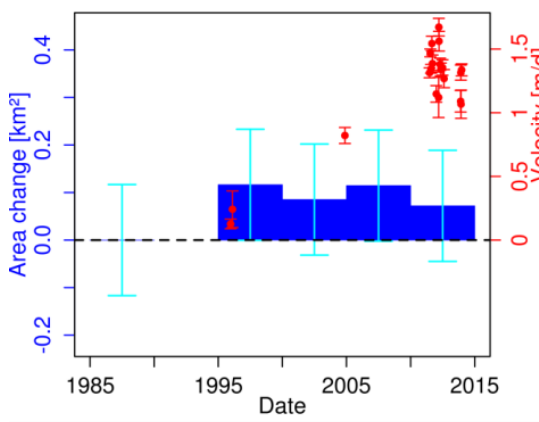

Fig.: S63 TPE39 Glacier

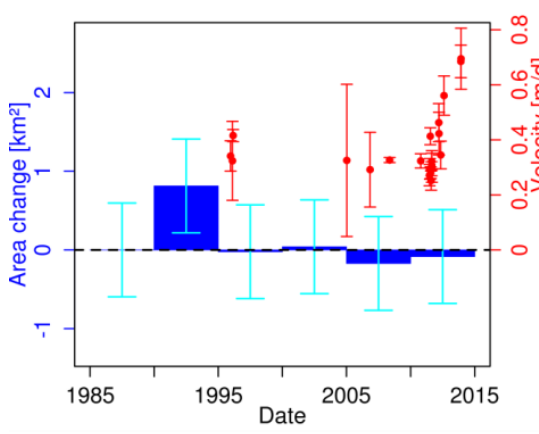

Fig.: S66 TPE46 Glacier

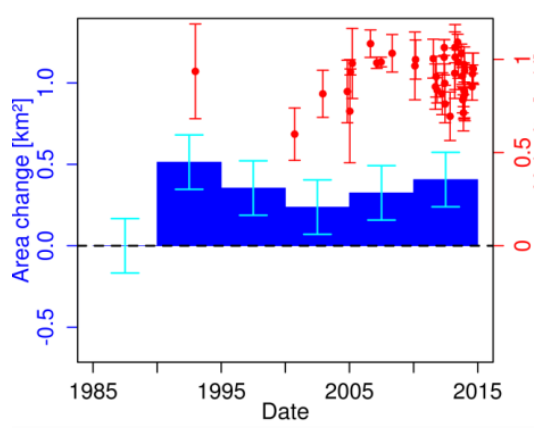

Fig.: S69

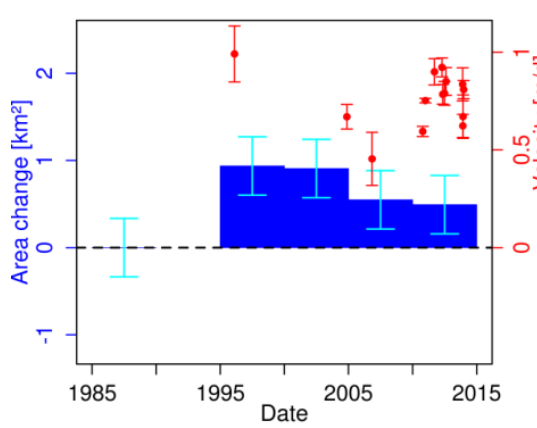

Fig.: S58 Stringfellow-Henson glaciers

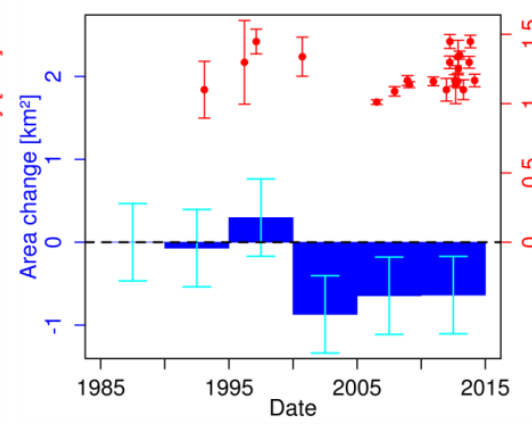

Fig.: S61

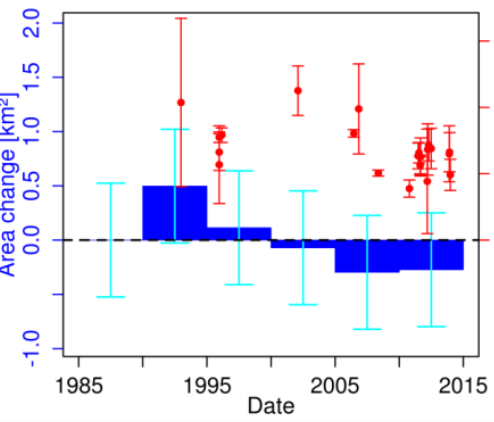

Fig.: S64

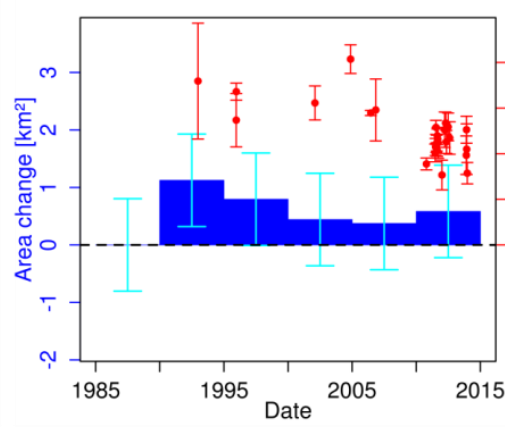

Fig.: S67

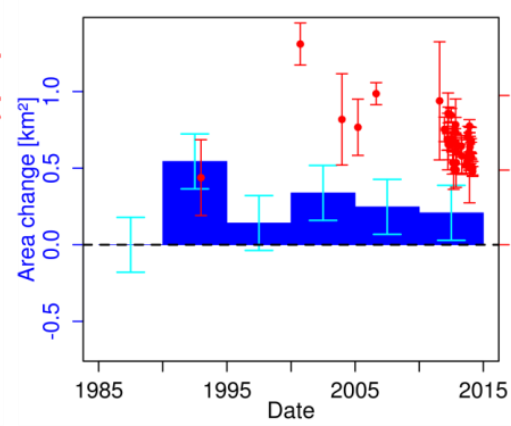

Fig.: S70 TPE9 Glacier

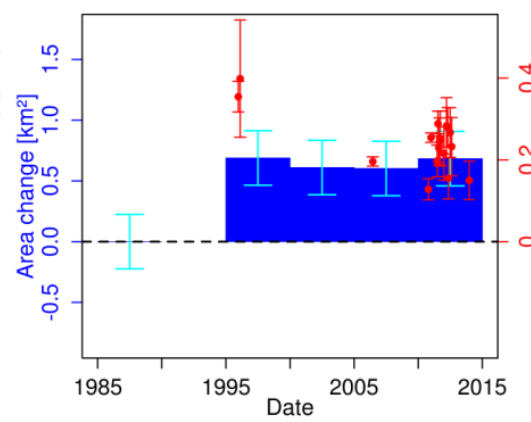

Fig.: S59

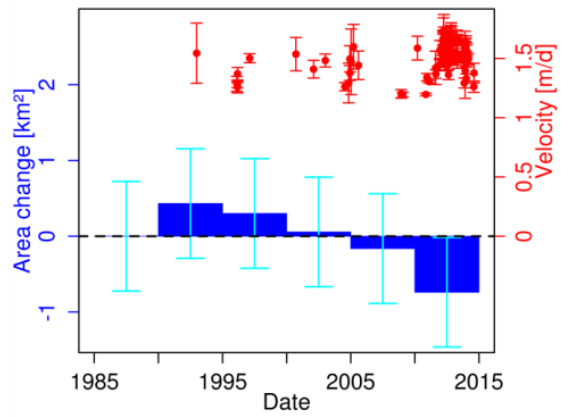

Fig.: S62 TPE126 Glacier

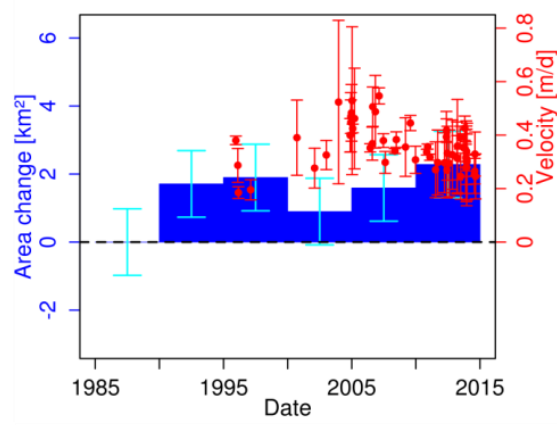

Fig.: S65 TPE41 Glacier

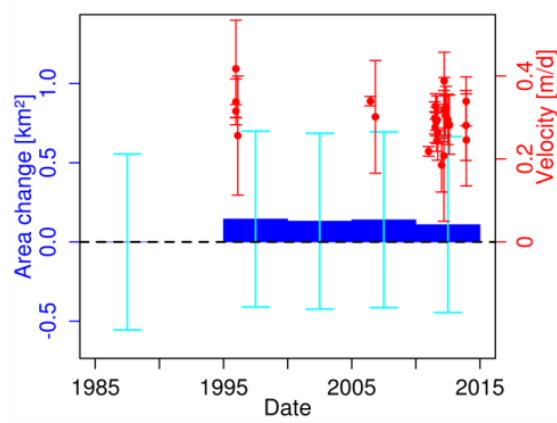

Fig.: S68 TPE57 Glacier

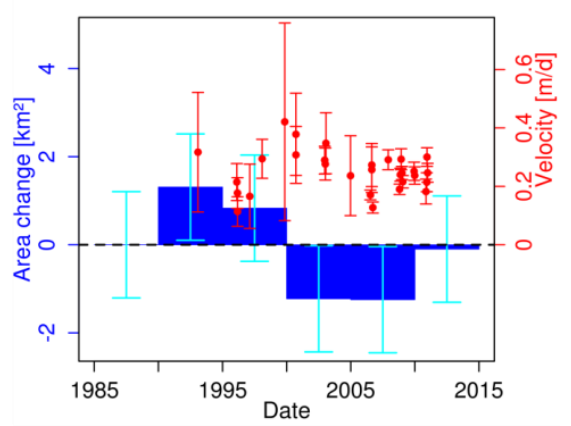

Fig.: S71 Wellman Glacier

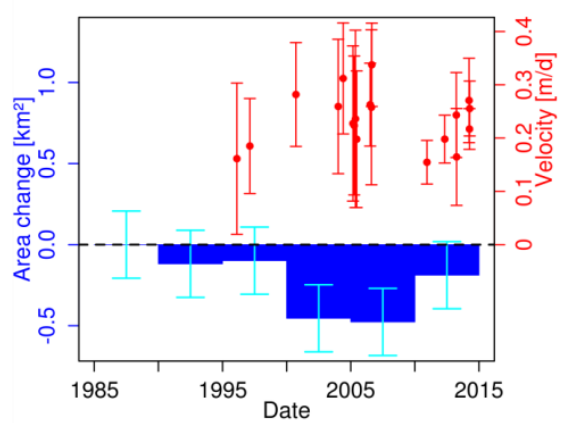

Figure S57-S71. Temporal changes of surface velocity (median values of measurements along terminus profiles) (red) and area (blue) changes of glaciers in sector "West". 

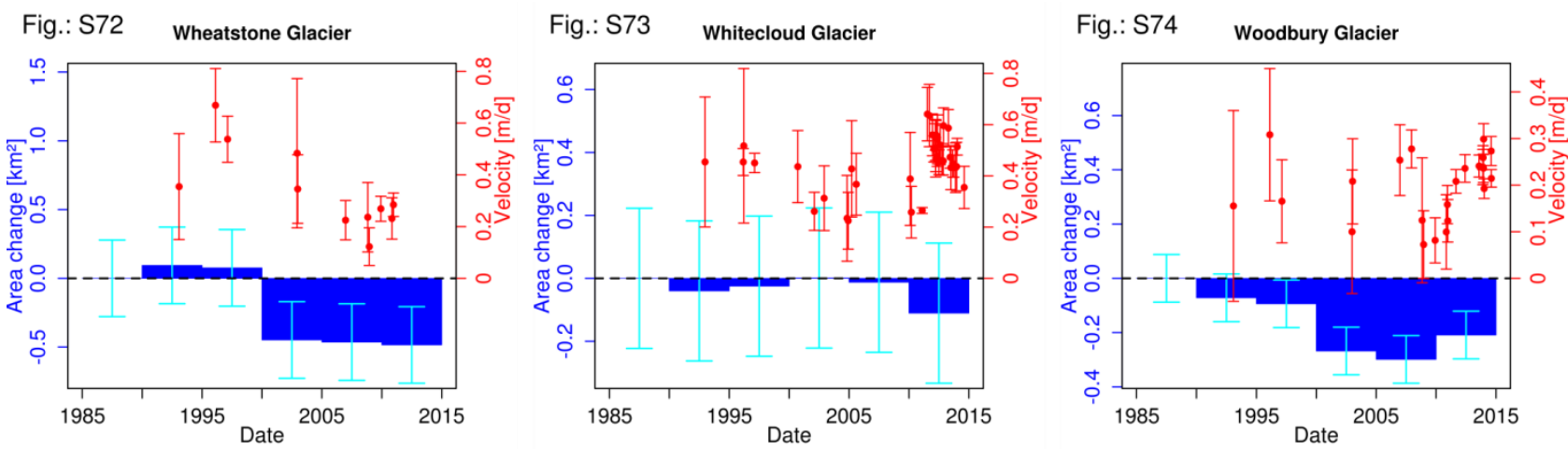

Figure S72-S74. Temporal changes of surface velocity (median values of measurements along terminus profiles) (red) and area (blue) changes of glaciers in sector "West". 
Fig.: S75 ADD ID: 2707 Glacier

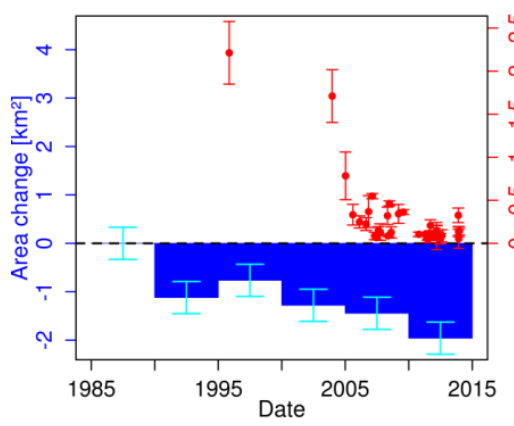

Fig.: S78 Broad Valley Glacier

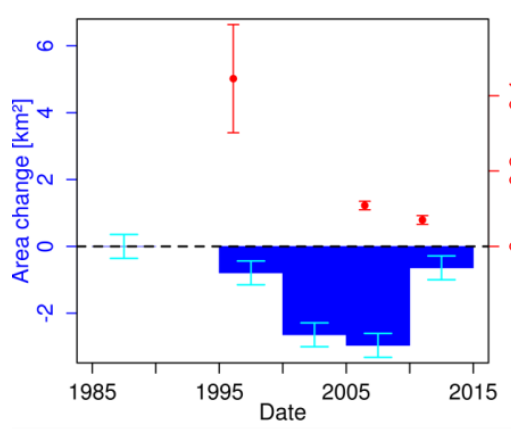

Fig.: S81 Russell East Glacier

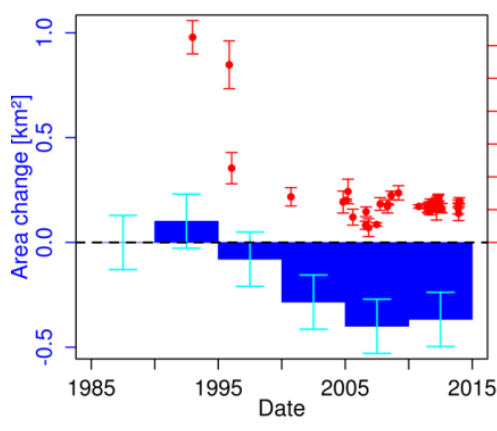

Fig.: S84 TPE31 Glacier

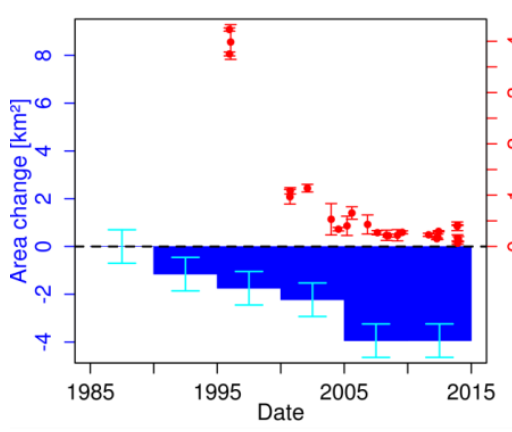

Fig.: S87 Victory Glacier

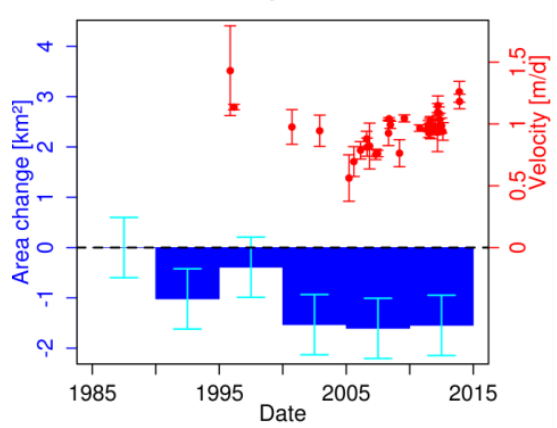

Figure S75-S87. Temporal trend of surface velocity measured at maximum ice thickness at terminus profiles (red) and area (blue) changes of glaciers in sector "East".
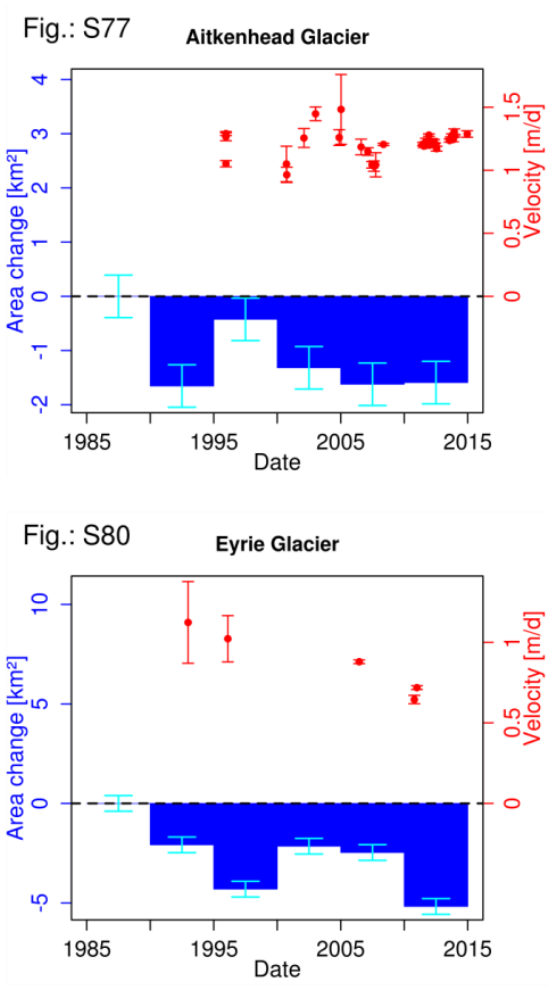

Fig.: S83 TPE130 Glacier
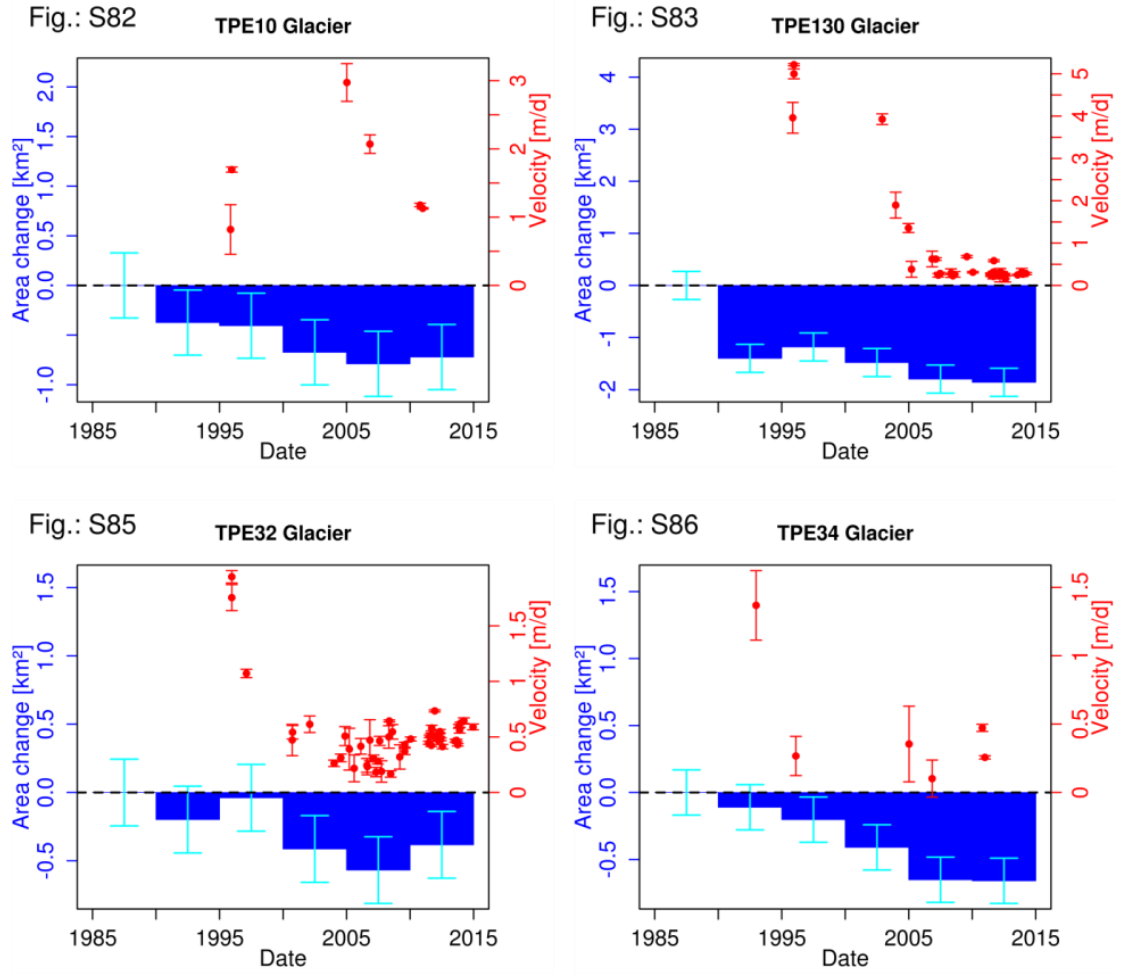
Fig.: S88 ADD ID: 2558 Glacier

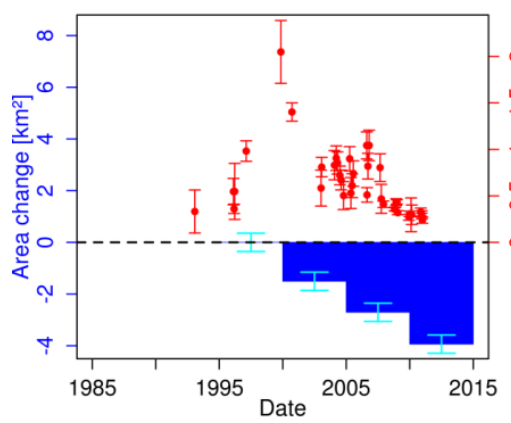

Fig.: S91 Arron Icefall Glacier

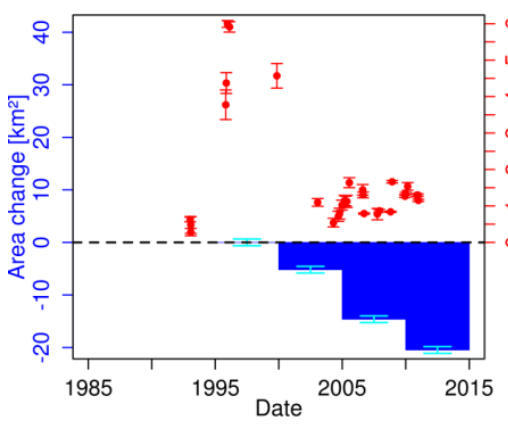

Fig.: S94

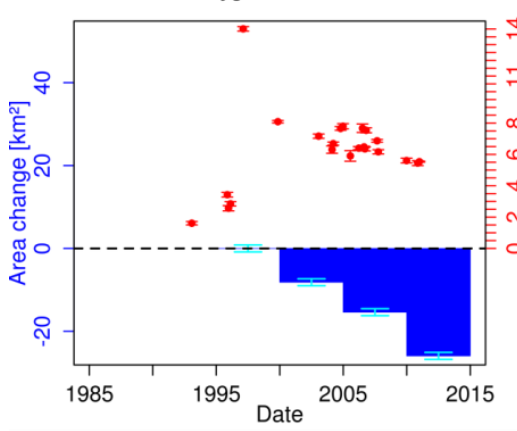

Fig.: S97 Sjögren Glacier

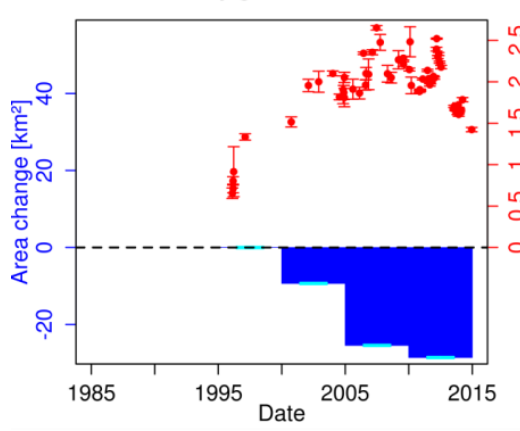

Fig.: S89

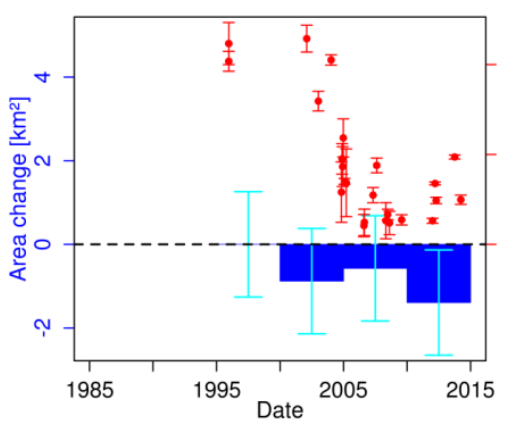

Fig.: S92

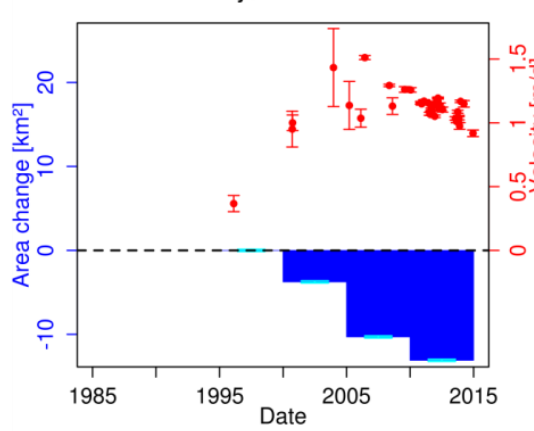

Fig.: S95

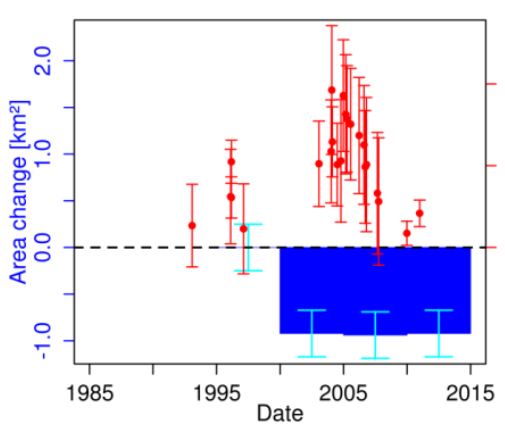

Fig.: S98 TPE114 Glacier

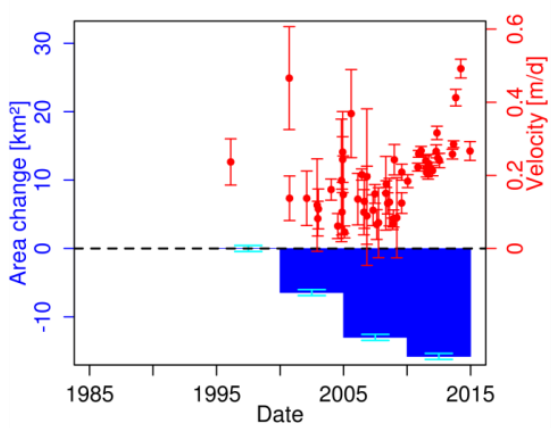

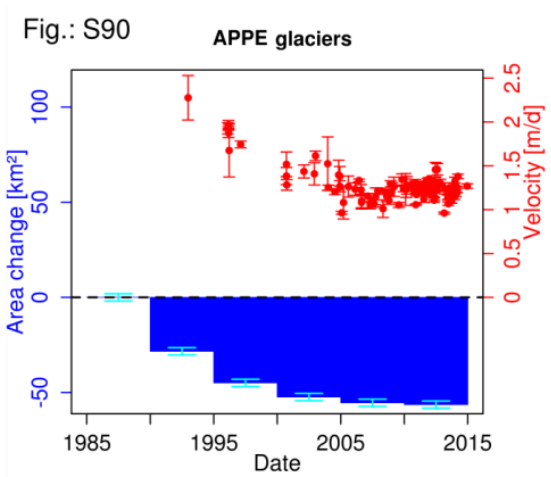

Fig.: S93 DBE glaciers

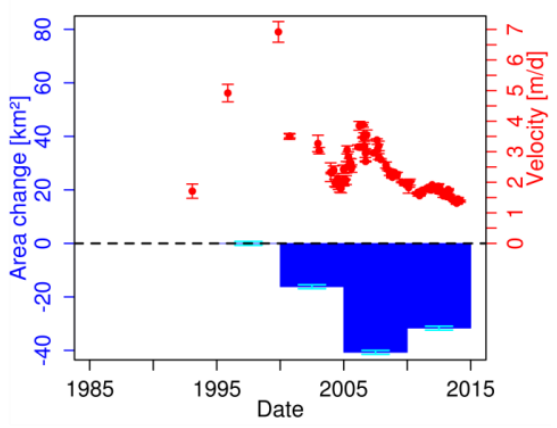

Fig.: S96 LAB32 Glacier

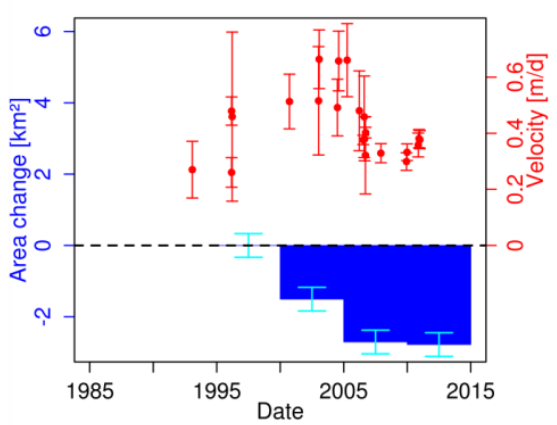

Fig.: S99 TPE61 Glacier

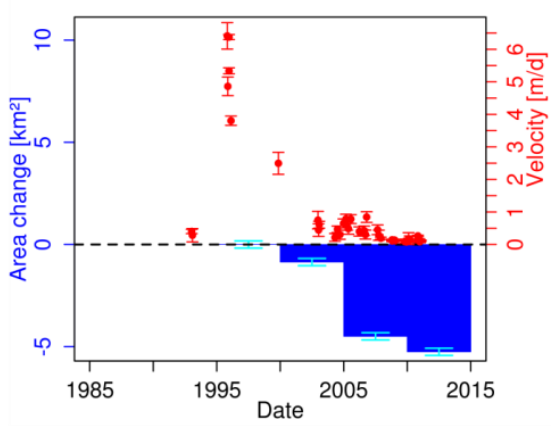

Fig.: S100 TPE62 Glacier

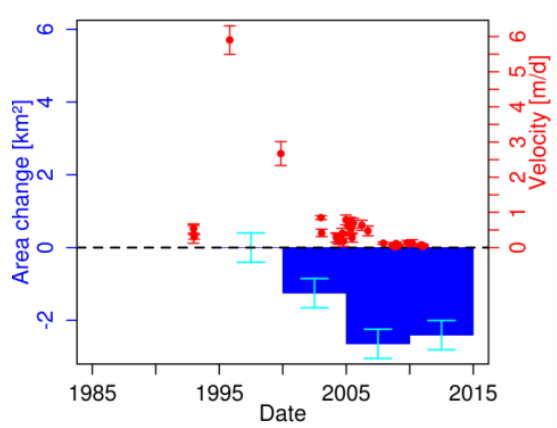

Figure S88-S100. Temporal trend of surface velocity measured at maximum ice thickness at terminus profiles (red) and area (blue) changes of glaciers in sector "EastIS". 

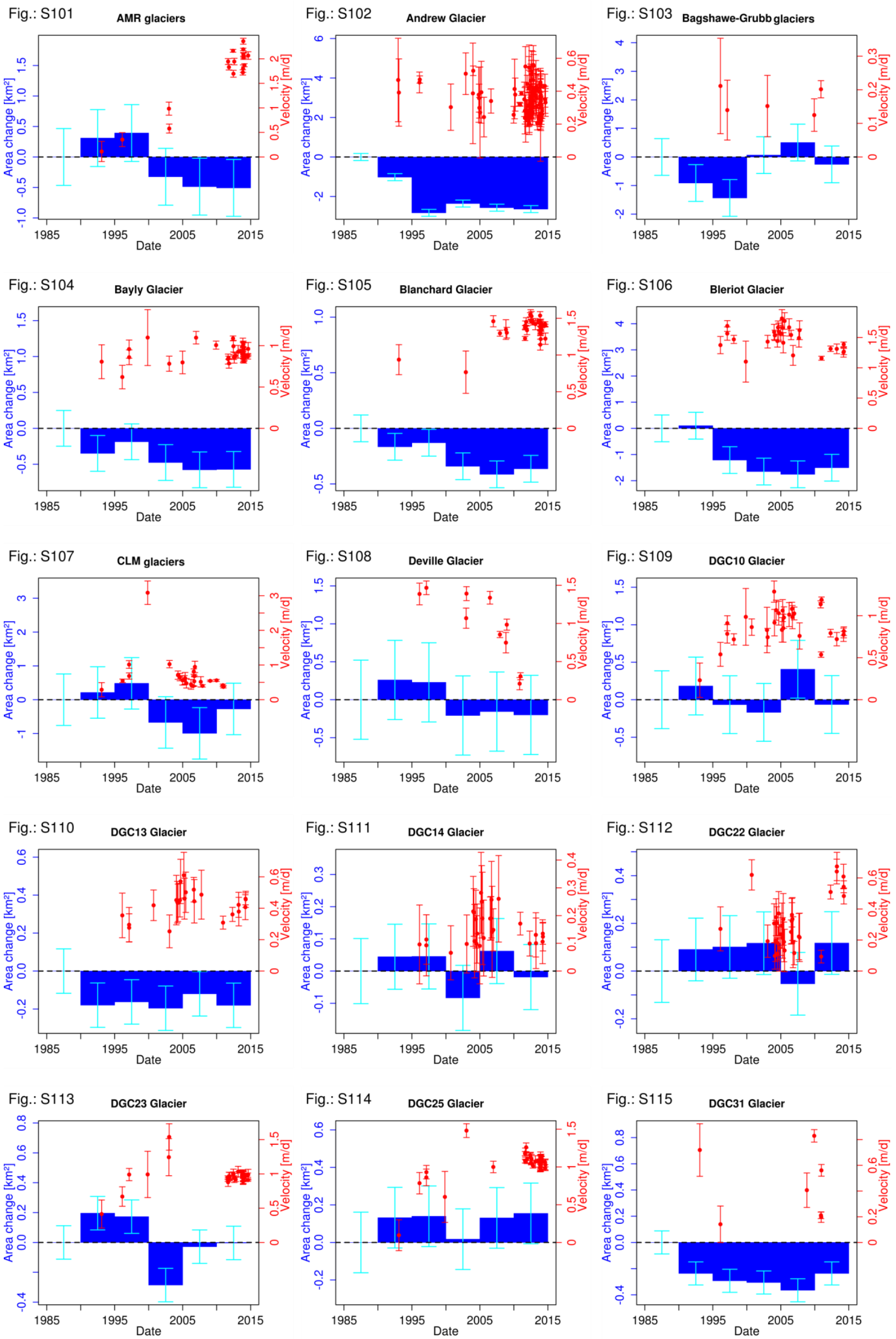

Fig.: S114 DGC25 Glacier

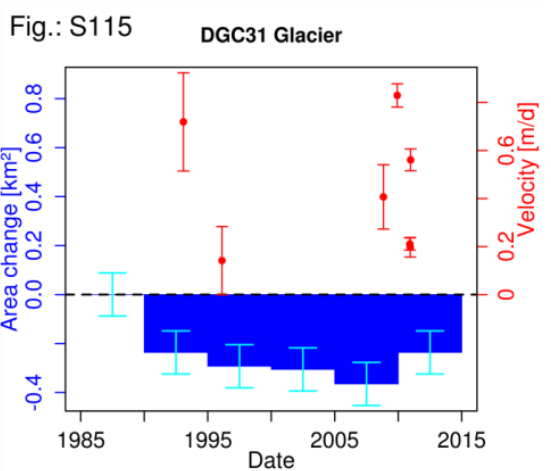

Figure S101-S115. Temporal trend of surface velocity measured at maximum ice thickness at terminus profiles (red) and area (blue) changes of glaciers in sector "West". 
Fig.: S116

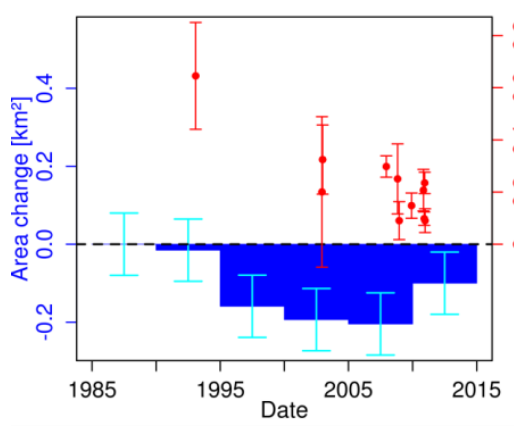

Fig.: S119

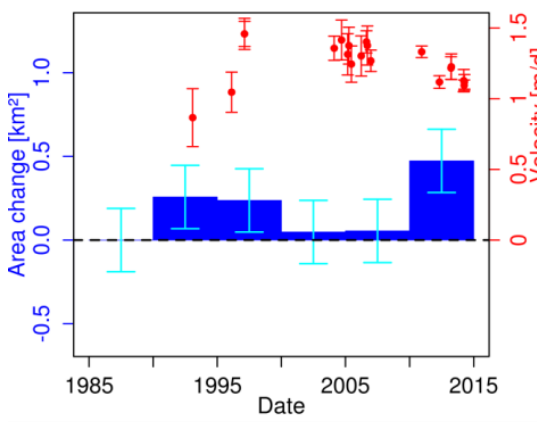

Fig.: S122 Mc Neile Glacier

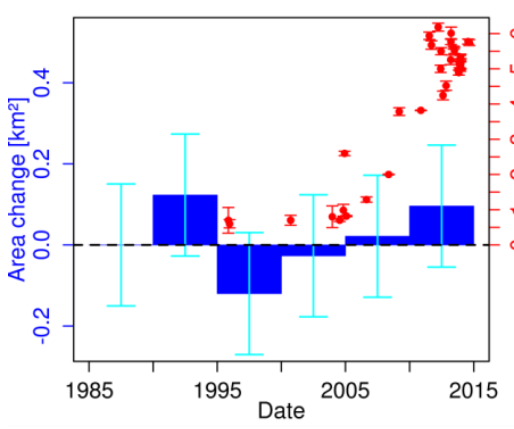

Fig.: S125 Orel Glacier

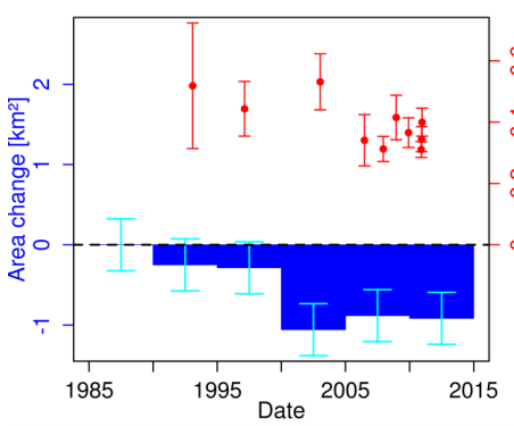

Fig.: S128 Rozier Glacier

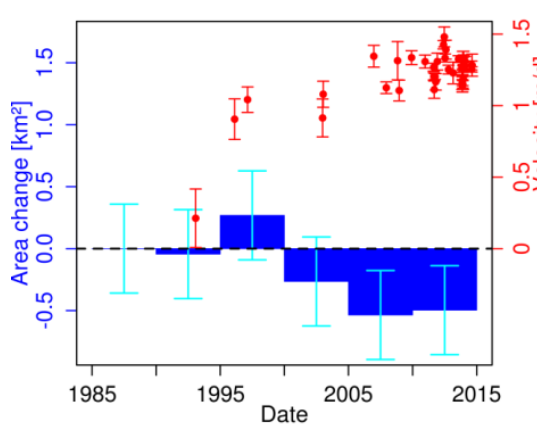

Fig.: $\mathrm{S} 117$

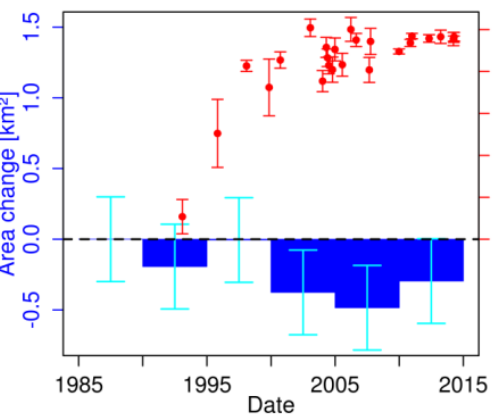

Fig.: $\$ 120$

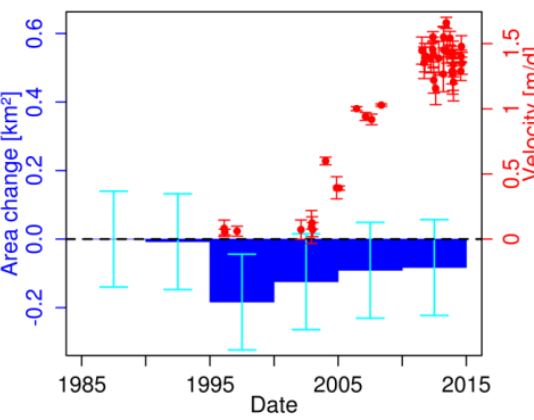

Fig.: S123 Montgolfier Glacier

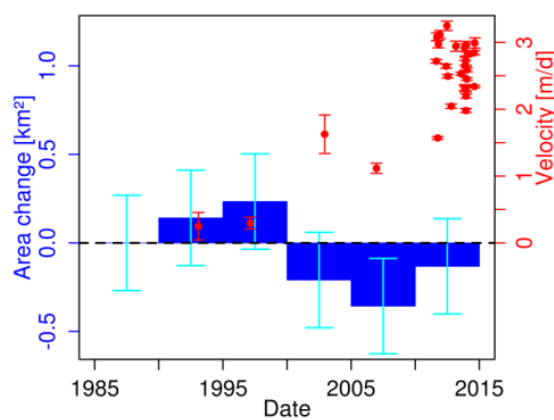

Fig.: S126 Pettus-Gavinlce glaciers

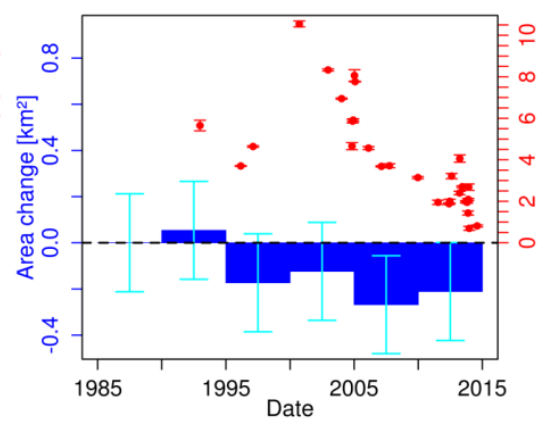

Fig.: S129 Russell West Glacier

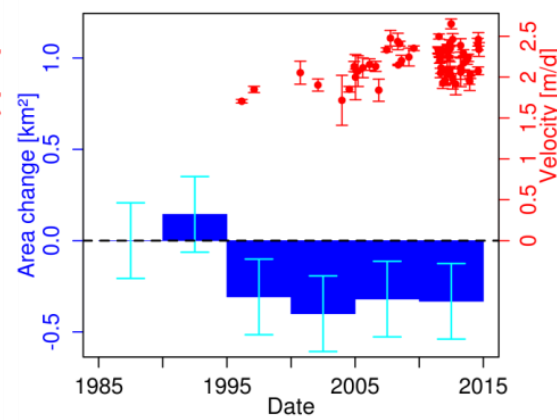

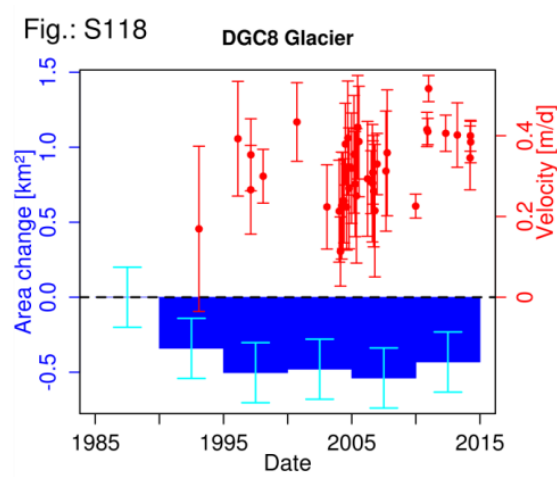

Fig.: S121 Leonardo Glacier

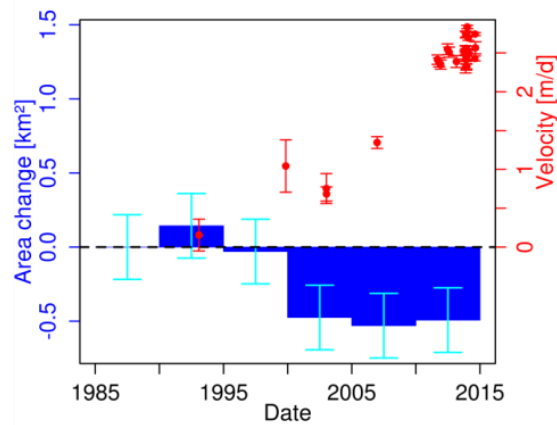

Fig.: S124 Nobile Glacier

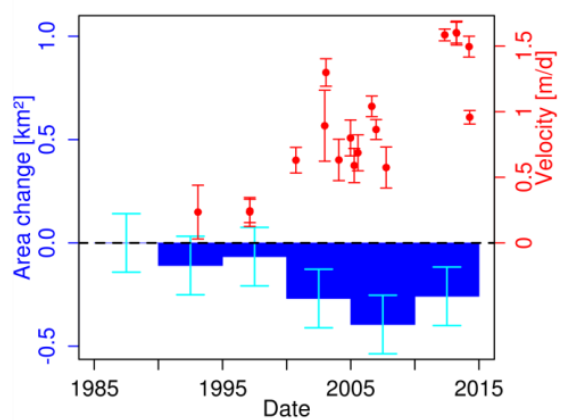

Fig.: S127 Renard Glacier

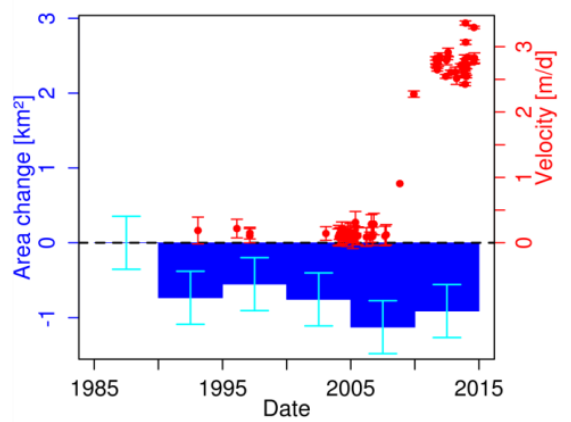

Fig.: $\$ 130 \quad$ Sabine Glacier

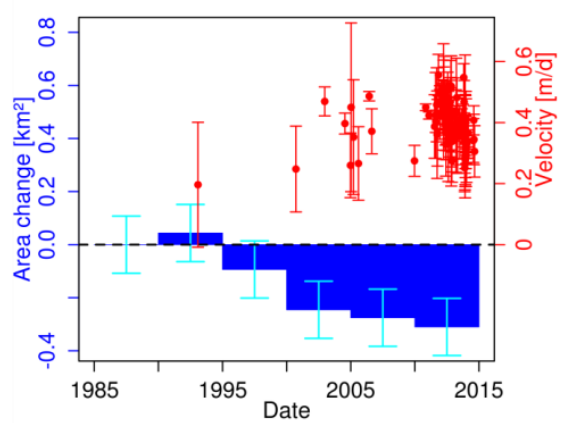

Figure S116-S130. Temporal trend of surface velocity measured at maximum ice thickness at terminus profiles (red) and area (blue) changes of glaciers in sector "West". 


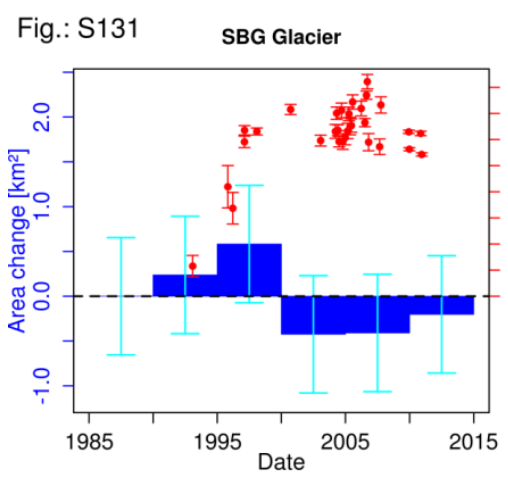

Fig.: S134

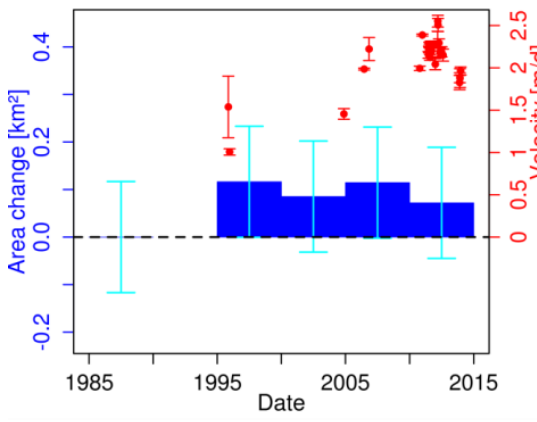

Fig.: $\mathrm{S} 137$

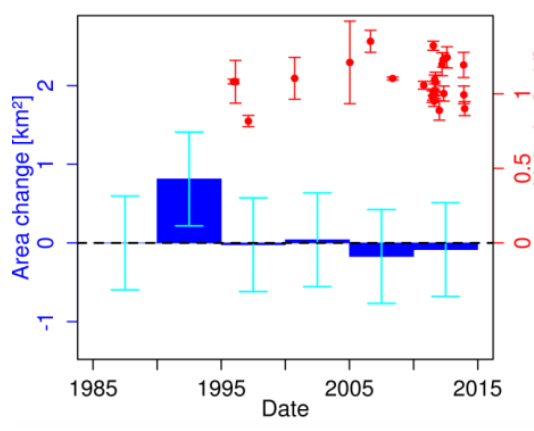

Fig.: S140 TPE46 Glacier

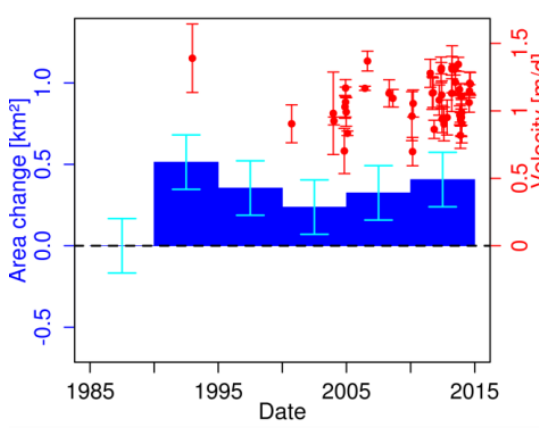

Fig.: S143 TPE8 Glacier

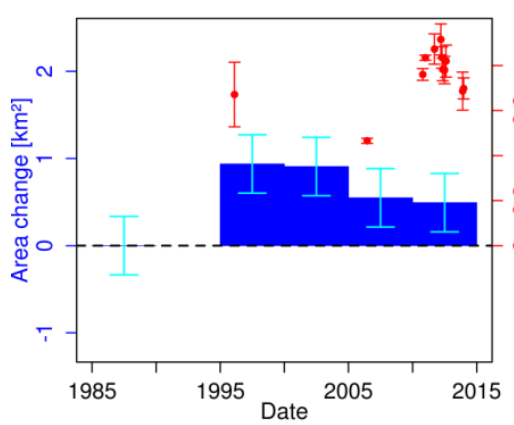

Fig.: S132 Stringfellow-Henson glaciers

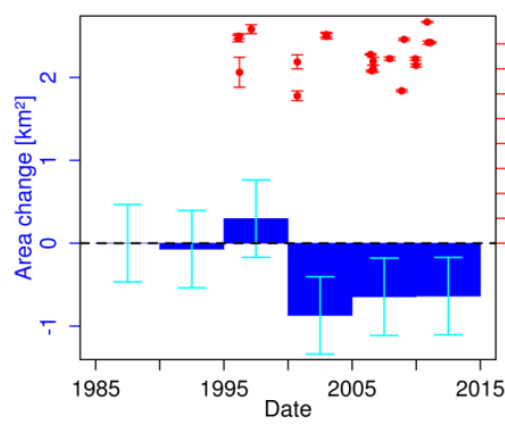

Fig.: S135

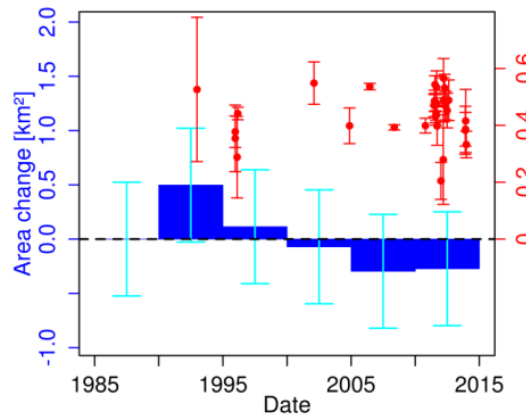

Fig.: S138 TPE40 Glacier

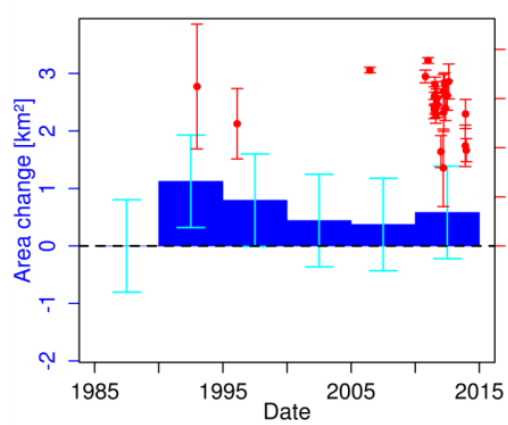

Fig.: S141 TPE50 Glacier

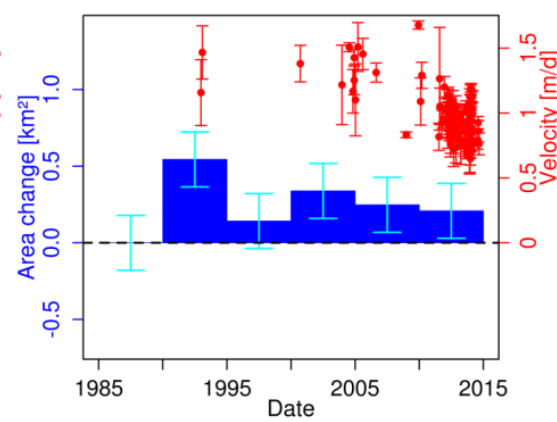

Fig.: S144 TPE9 Glacier

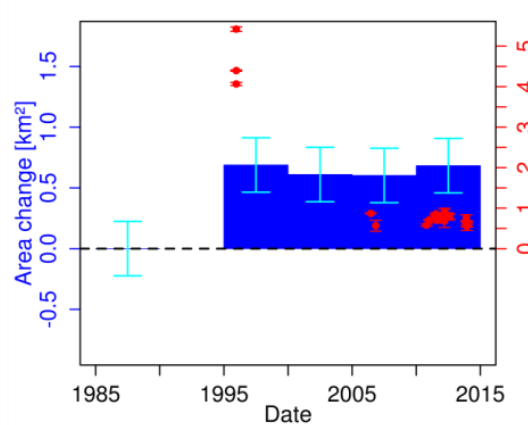

Fig.: S133 Temple Glacier

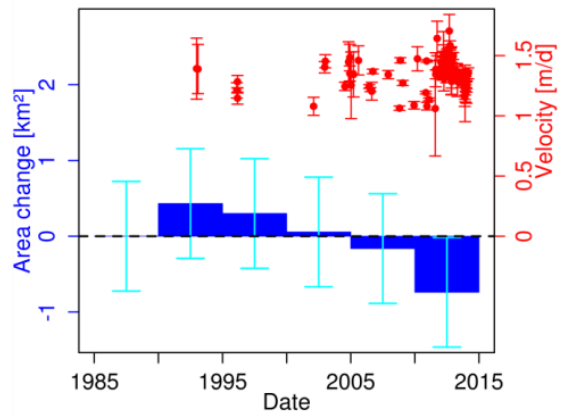

Fig.: S136 TPE126 Glacier

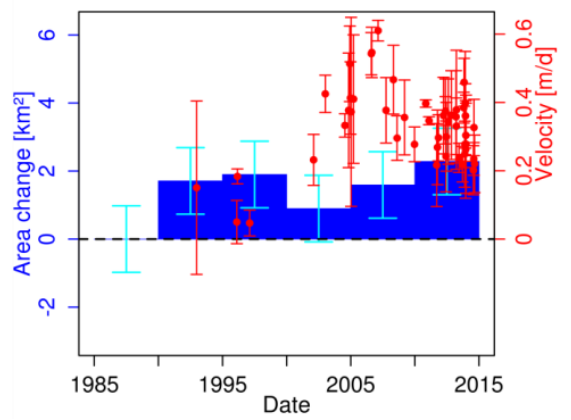

Fig.: S139 TPE41 Glacier

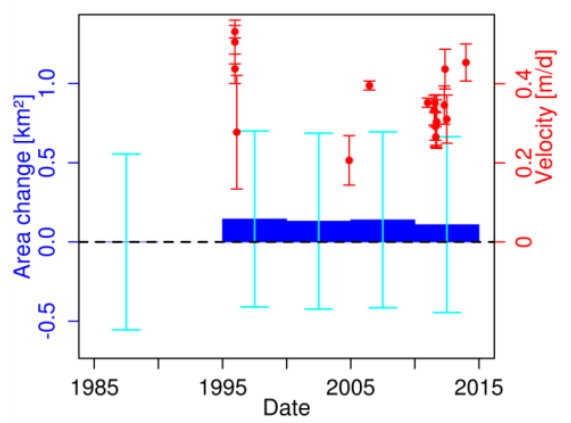

Fig.: S142 TPE57 Glacier

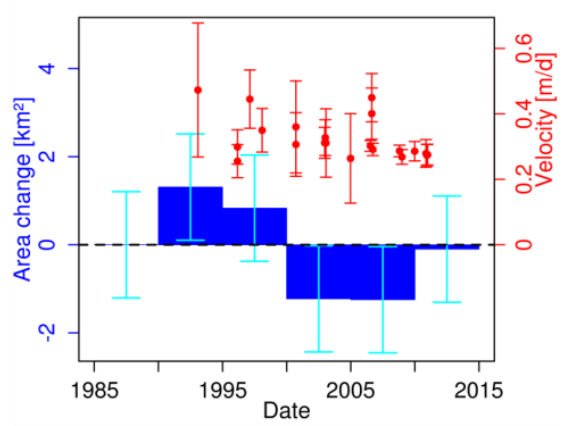

Fig.: S145 Wellman Glacier

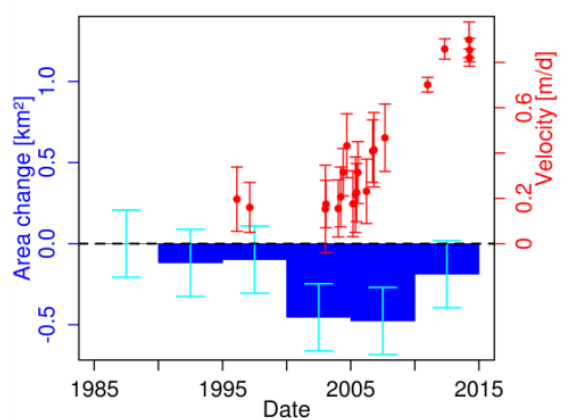

Figure S131-S145. Temporal trend of surface velocity measured at maximum ice thickness at terminus profiles (red) and area (blue) changes of glaciers in sector "West". 
Fig.: S146

Wheatstone Glacier

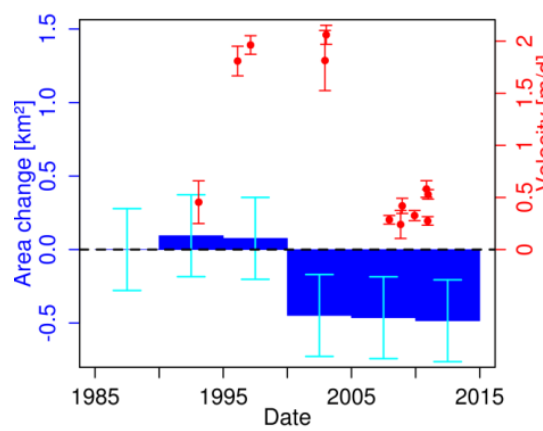

Fig.: S147

Whitecloud Glacier

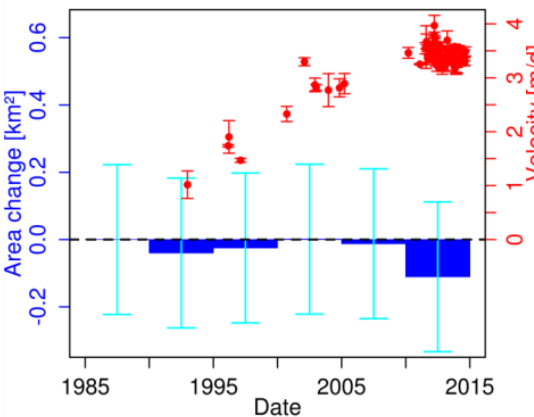

Fig.: S148 Woodbury Glacier

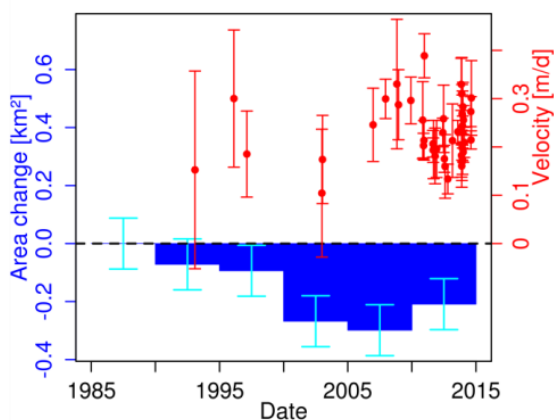

Figure S146-S148. Temporal trend of surface velocity measured at maximum ice thickness at terminus profiles (red) and area (blue) changes of glaciers in sector "West". 


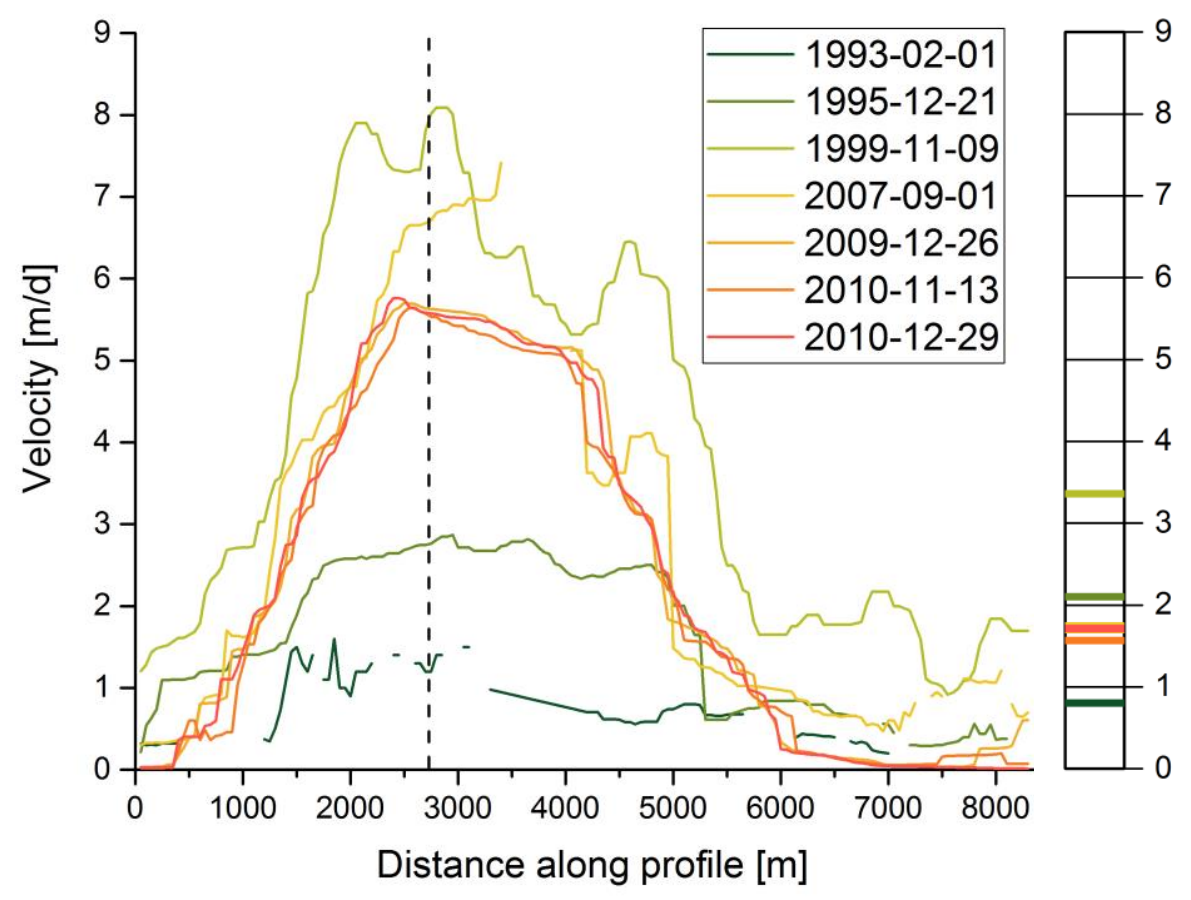

Figure S149. Surface velocity across the terminus of Drygalski Glacier (left) and median values of each profile (right). Dashed line: maximum ice thickness of across glacier profile; Dates in legend: mean dates of SAR acquisitions used to calculate the surface velocity fields.

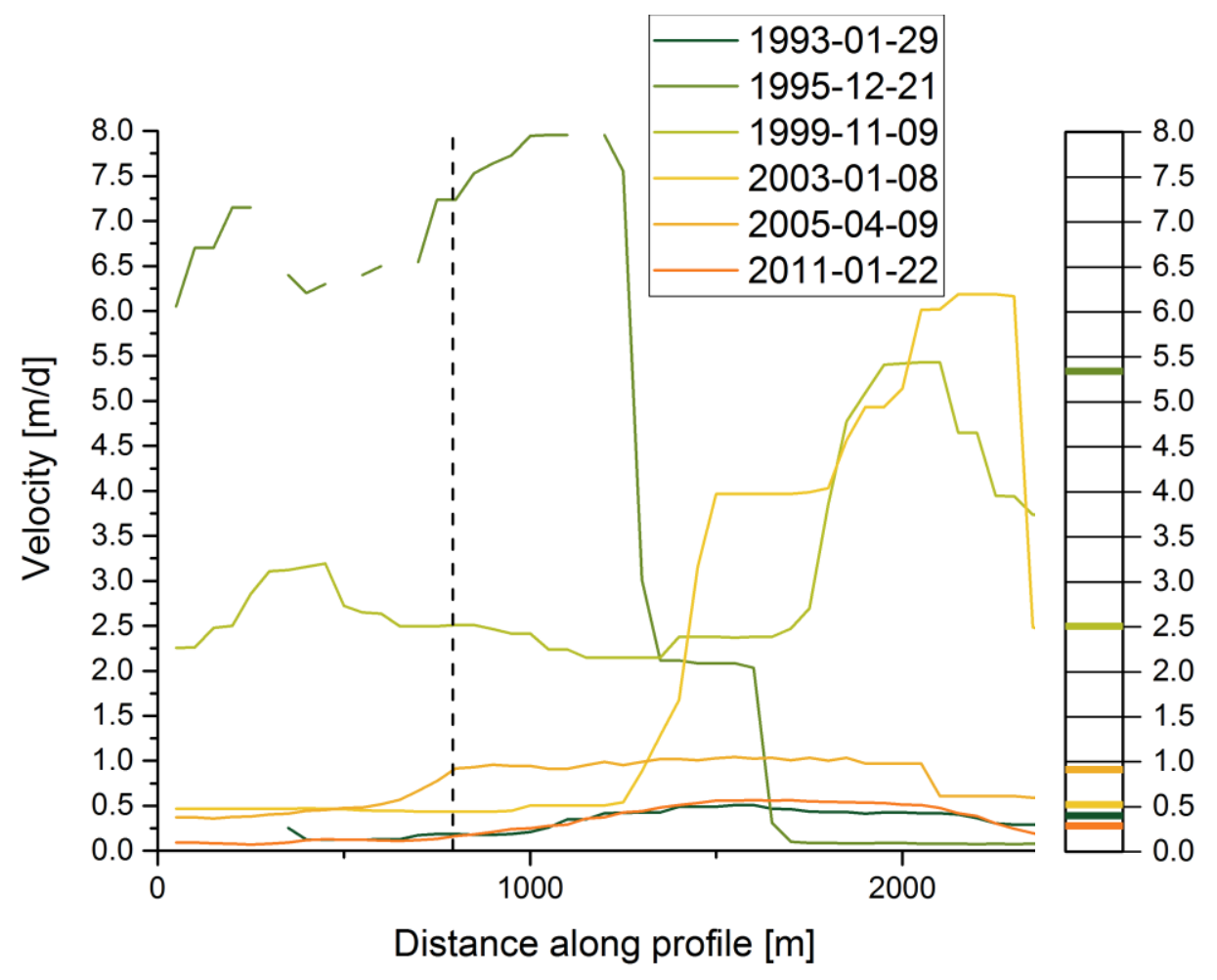

Figure S150. Surface velocity across the terminus of TPE61 Glacier (left) and median values of each profile (right). Dashed line: maximum ice thickness of across glacier profile; Dates in legend: mean dates of SAR acquisitions used to calculate the surface velocity fields. 


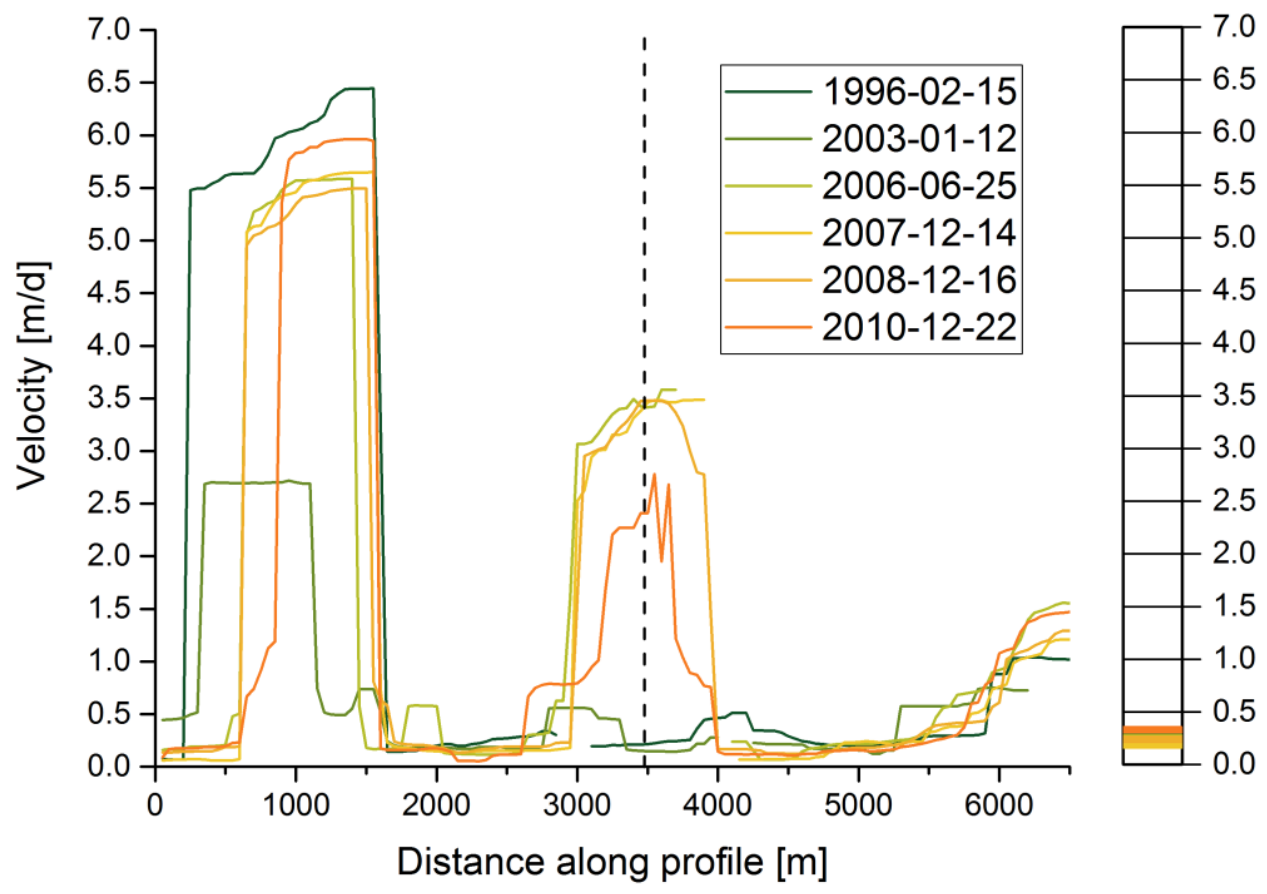

Figure S151. Surface velocity across the terminus of Bagshawe-Grubb glaciers (left) and median values of each profile (right). Dashed line: maximum ice thickness of across glacier profile; Dates in legend: mean dates of SAR acquisitions used to calculate the surface velocity fields.

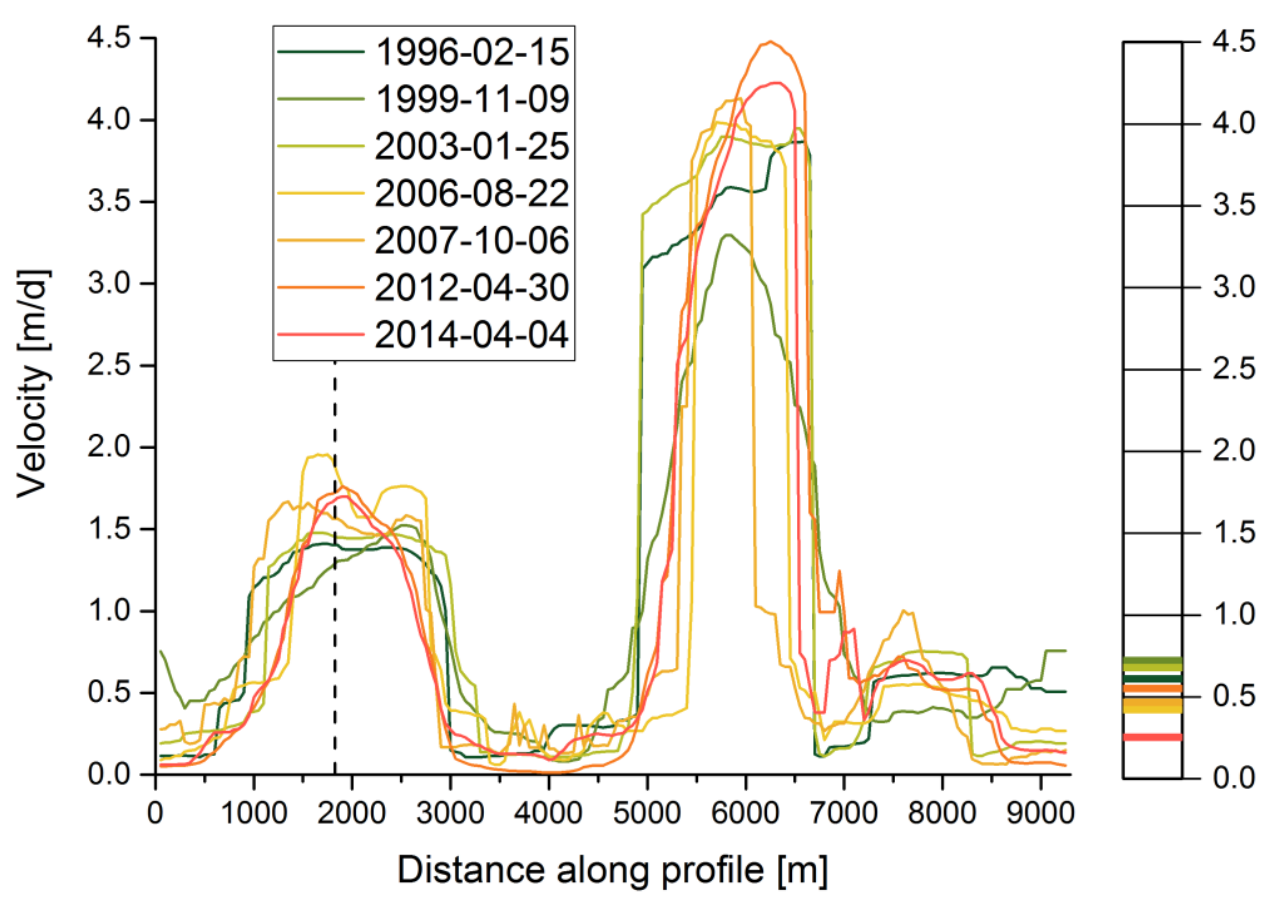

Figure S152. Surface velocity across the terminus of Bleriot Glacier (left) and median values of each profile (right). Dashed line: maximum ice thickness of across glacier profile; Dates in legend: mean dates of SAR acquisitions used to calculate the surface velocity fields. 


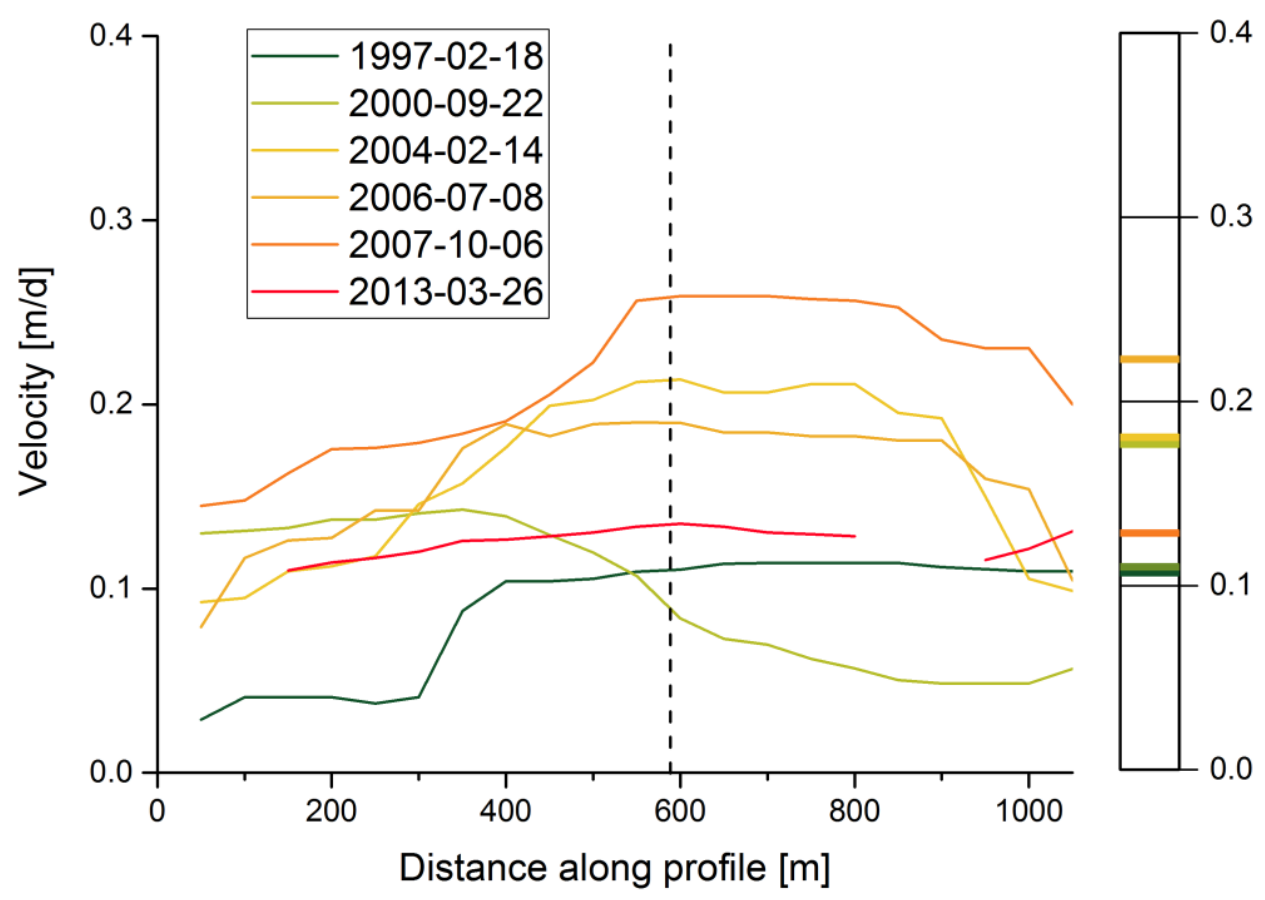

Figure S153. Surface velocity across the terminus of DGC14 Glacier (left) and median values of each profile (right). Dashed line: maximum ice thickness of across glacier profile; Dates in legend: mean dates of SAR acquisitions used to calculate the surface velocity fields.

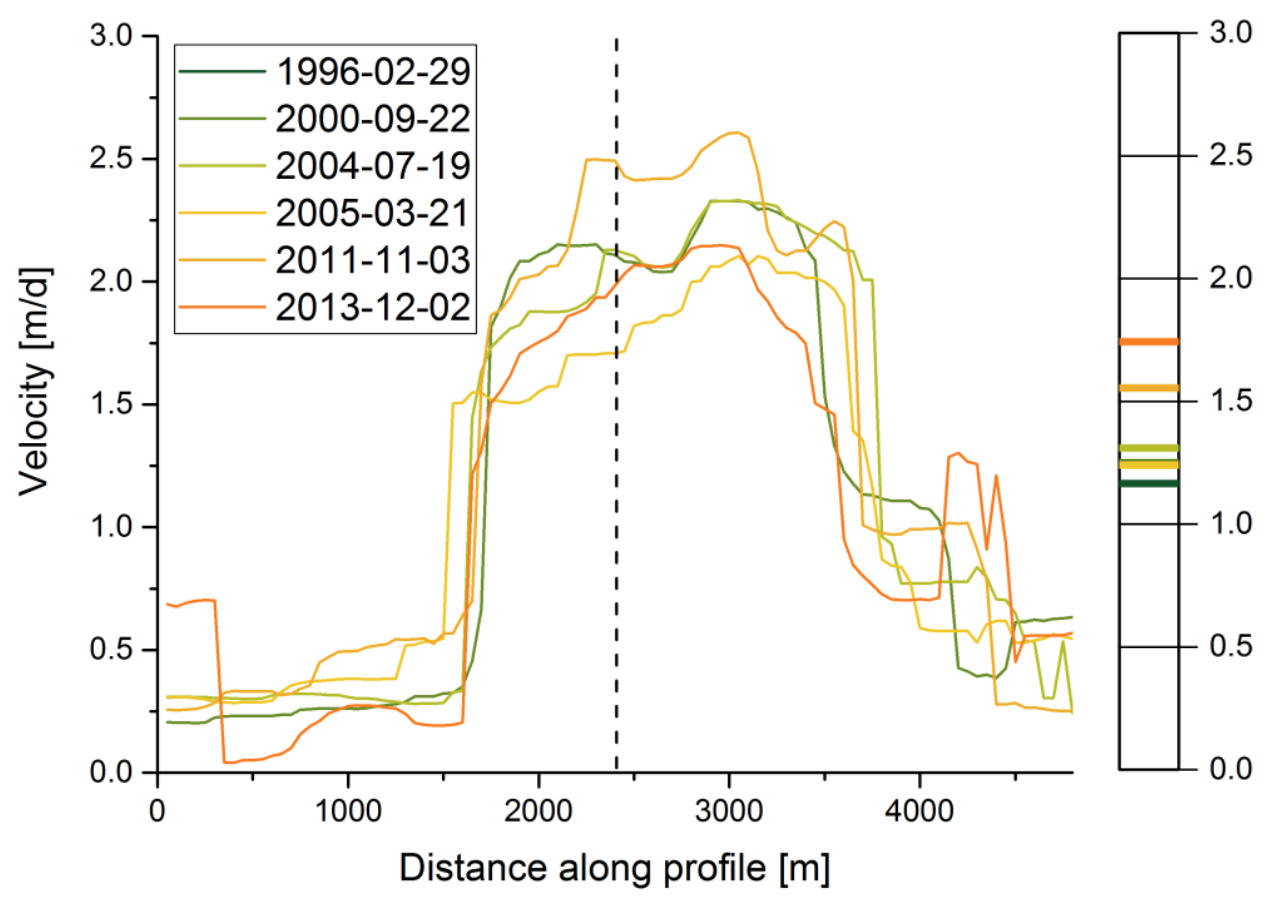

Figure S154. Surface velocity across the terminus of Russell West Glacier (left) and median values of each profile (right). Dashed line: maximum ice thickness of across glacier profile; Dates in legend: mean dates of SAR acquisitions used to calculate the surface velocity fields. 


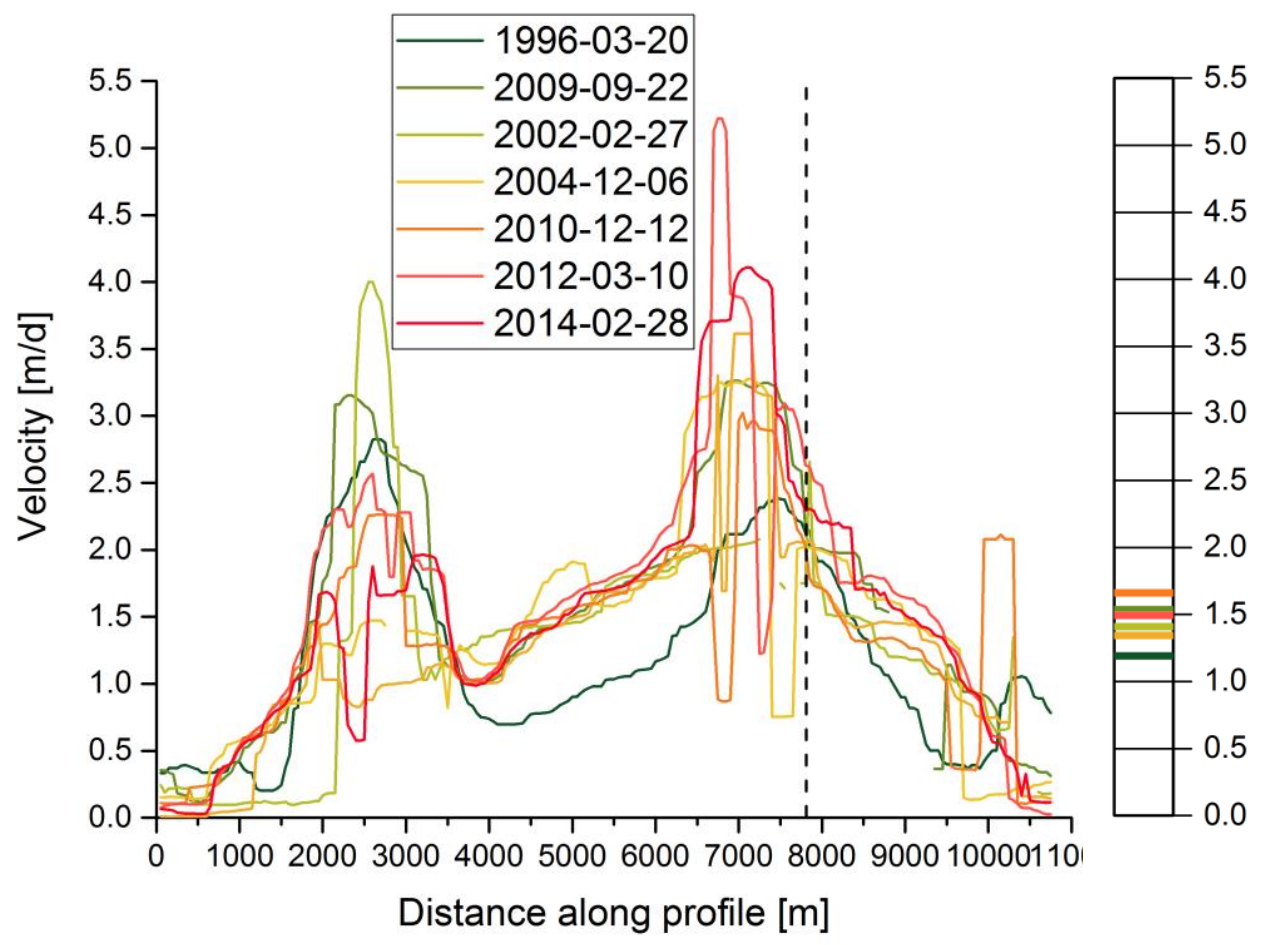

Figure S155. Surface velocity across the terminus of Temple Glacier (left) and median values of each profile (right). Dashed line: maximum ice thickness of across glacier profile; Dates in legend: mean dates of SAR acquisitions used to calculate the surface velocity fields.

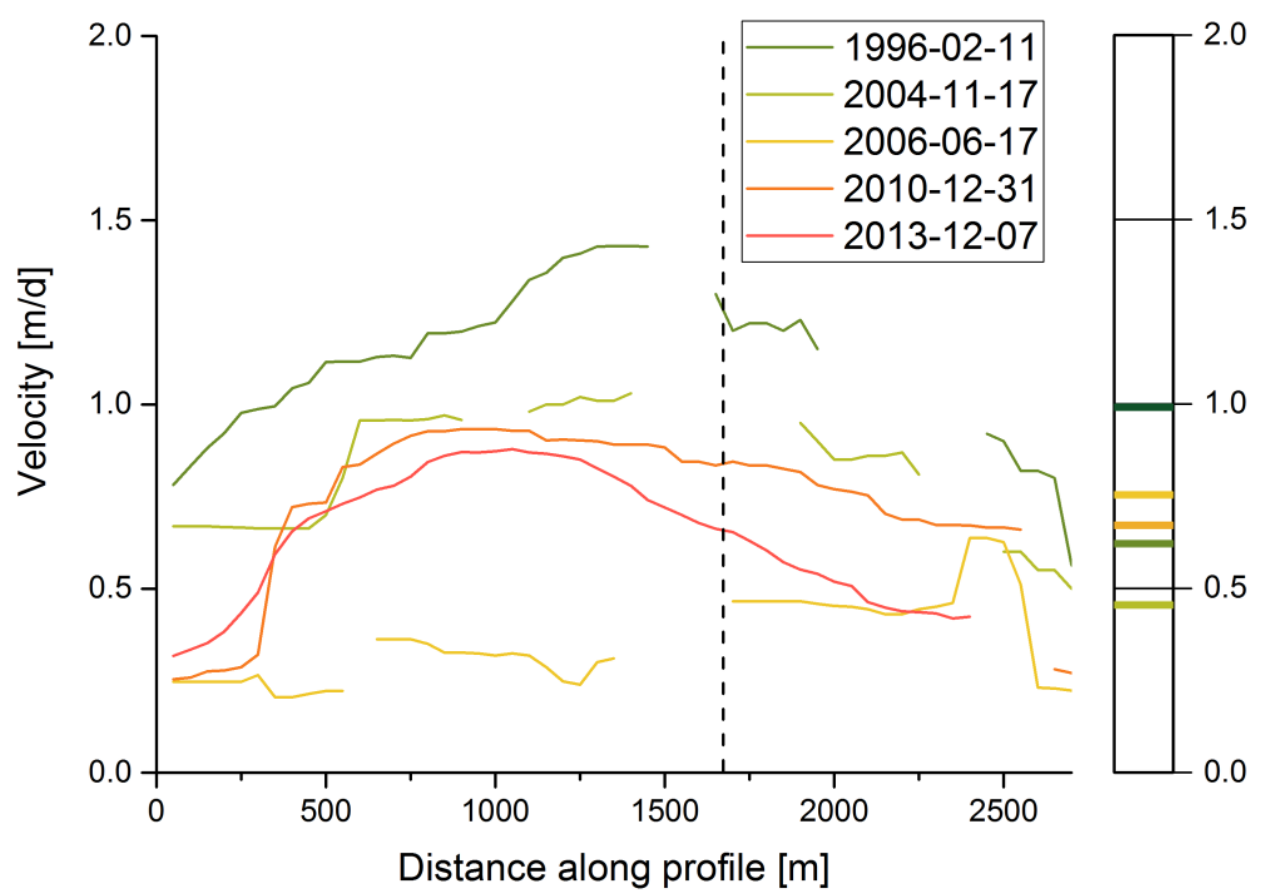

Figure S156. Surface velocity across the terminus of TPE8 Glacier (left) and median values of each profile (right). Dashed line: maximum ice thickness of across glacier profile; Dates in legend: mean dates of SAR acquisitions used to calculate the surface velocity fields. 


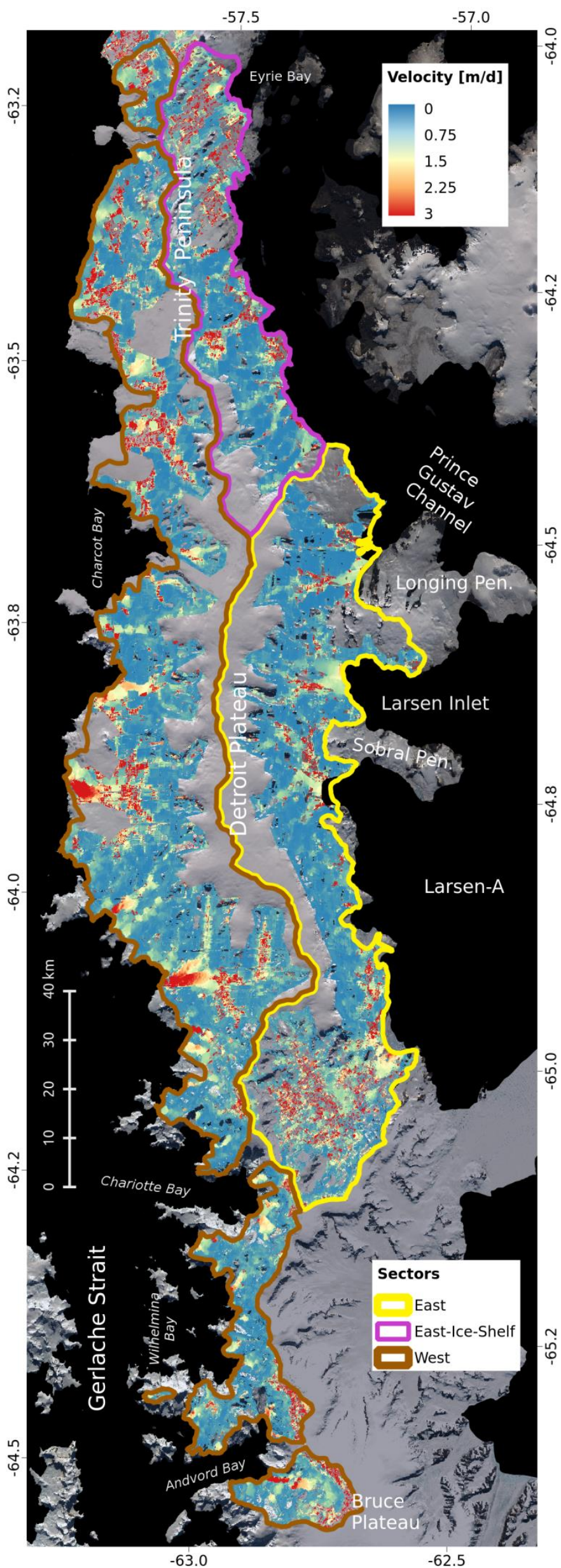

Figure S157. Surface velocity fields of outlet glaciers derived from multiple ERS SAR acquisitions (1996-1997). Background: Landsat LIMA Mosaic USGS, NASA, BAS, NSF. Note: Red speckle patterns indicate erroneous tracking results (noise). 


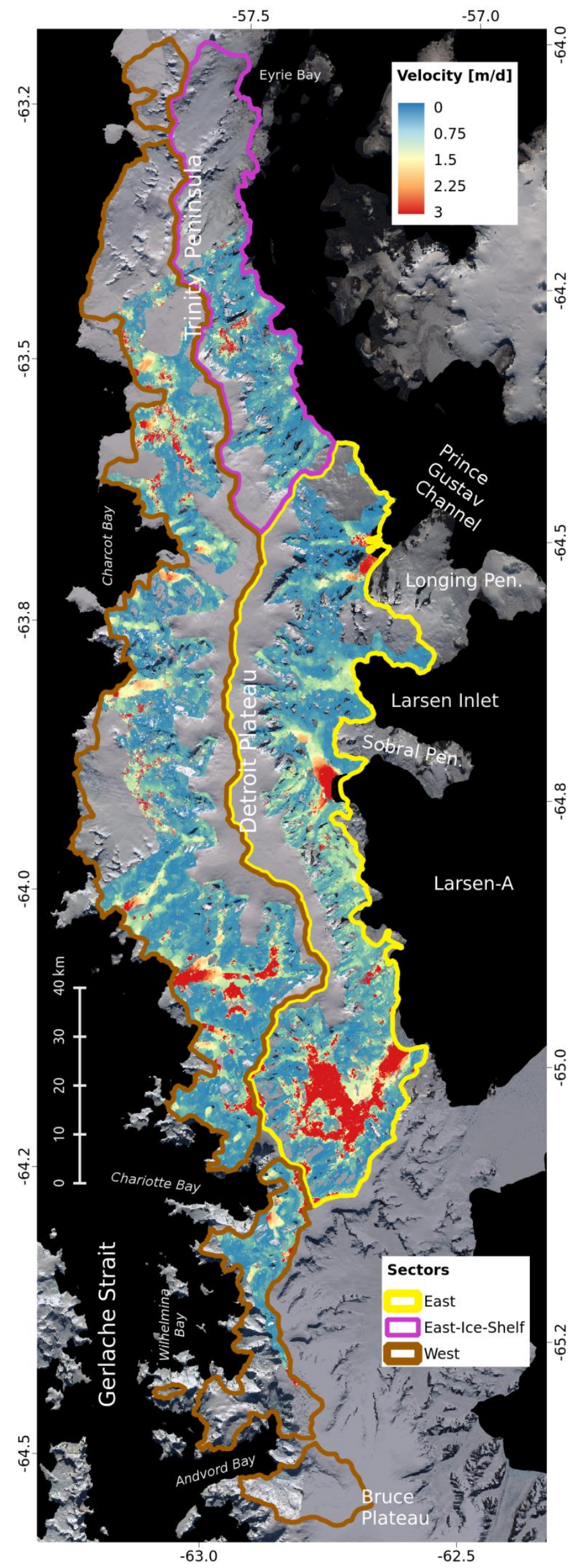

Figure S158. Surface velocity fields of outlet glaciers derived from multiple ENVISAT SAR acquisitions (20052006). Background: Landsat LIMA Mosaic USGS, NASA, BAS, NSF. Note: Red speckle patterns indicate erroneous tracking results (noise). 


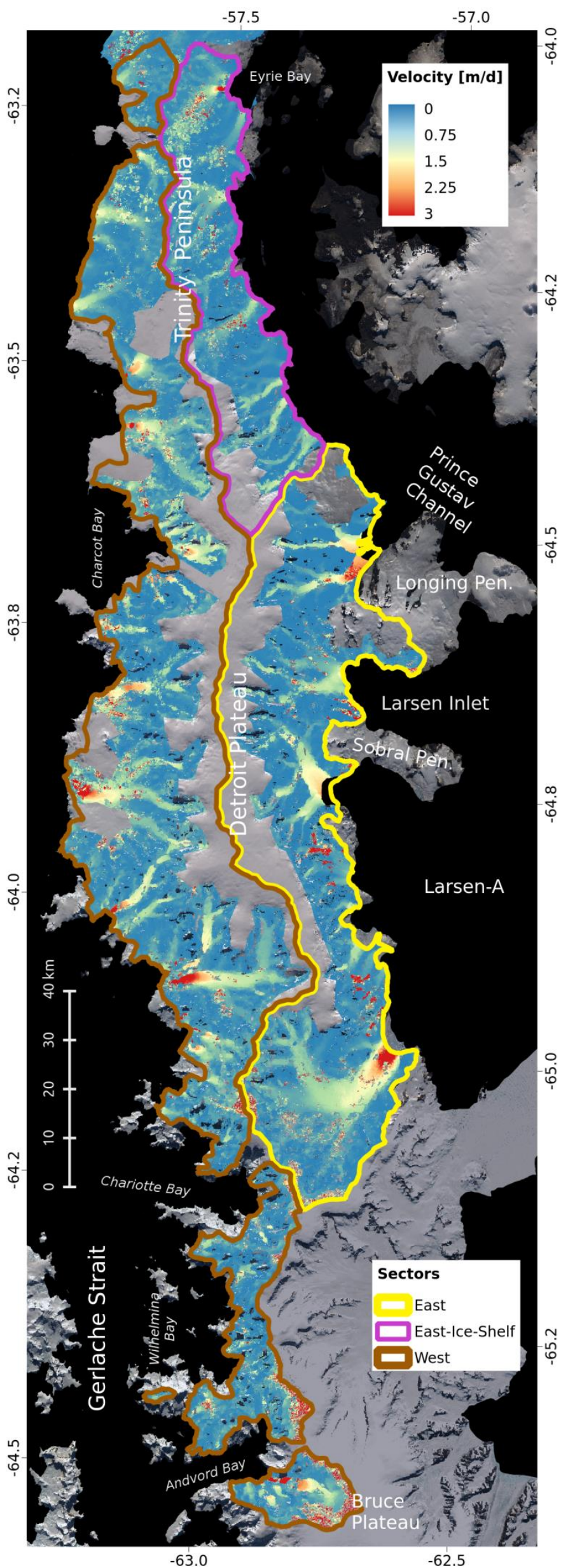

Figure S159. Surface velocity fields of outlet glaciers derived from multiple ALOS PALSAR acquisitions (20082010). Background: Landsat LIMA Mosaic USGS, NASA, BAS, NSF. Note: Red speckle patterns indicate erroneous tracking results (noise). 


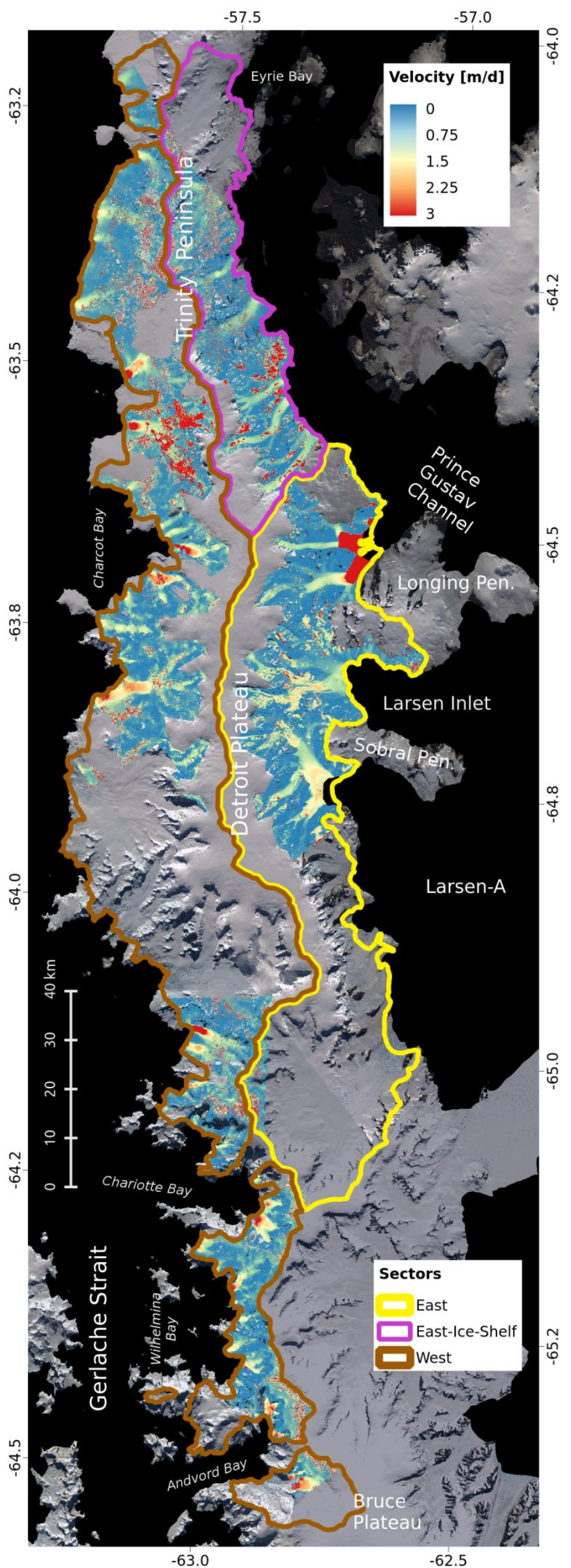

Figure S160. Surface velocity fields of outlet glaciers derived from multiple TerraSAR/TanDEM-X SAR acquisitions (2011-2012). Background: Landsat LIMA Mosaic USGS, NASA, BAS, NSF. Note: Red speckle patterns indicate erroneous tracking results (noise). 


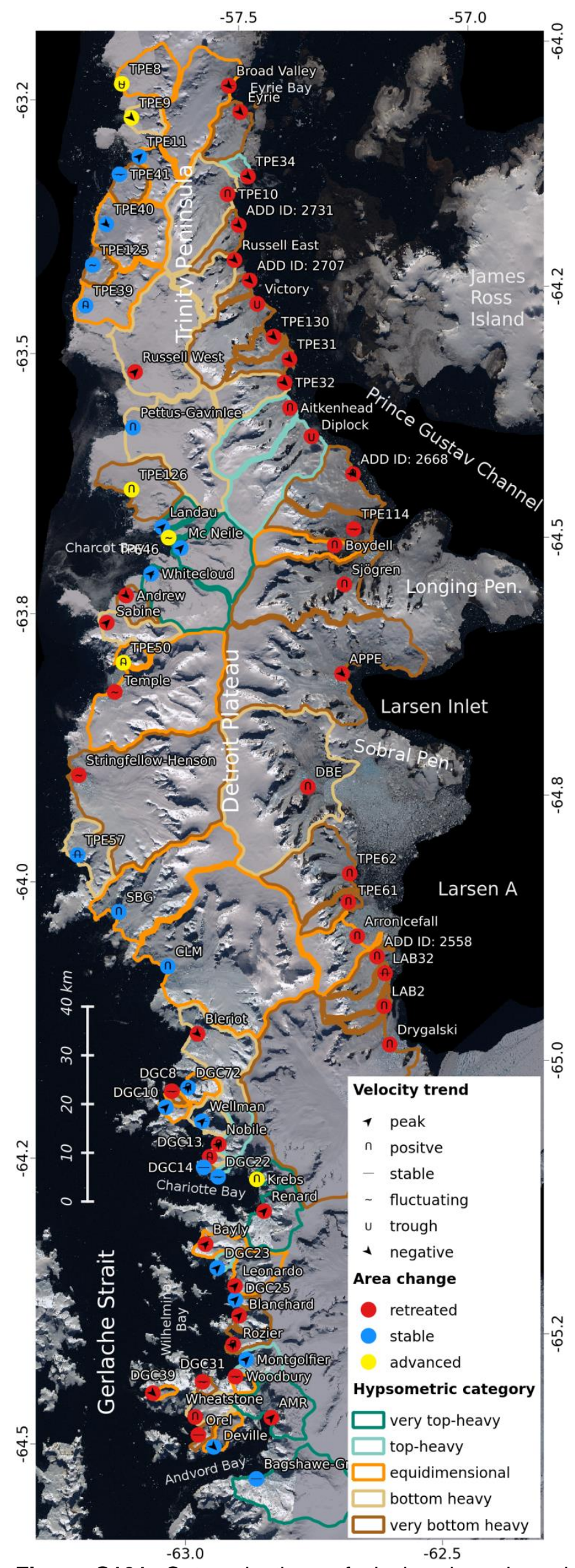

Figure S161. Categorizations of glaciers based on the temporal variations of area changes (dots) and flow velocities measured at maximum ice thickness at the terminus profiles (symbols). Colors of catchment delineation indicate Hypsometric categories according to Jiskoot et al. (2009). Background: Landsat LIMA Mosaic USGS, NASA, BAS, NSF 


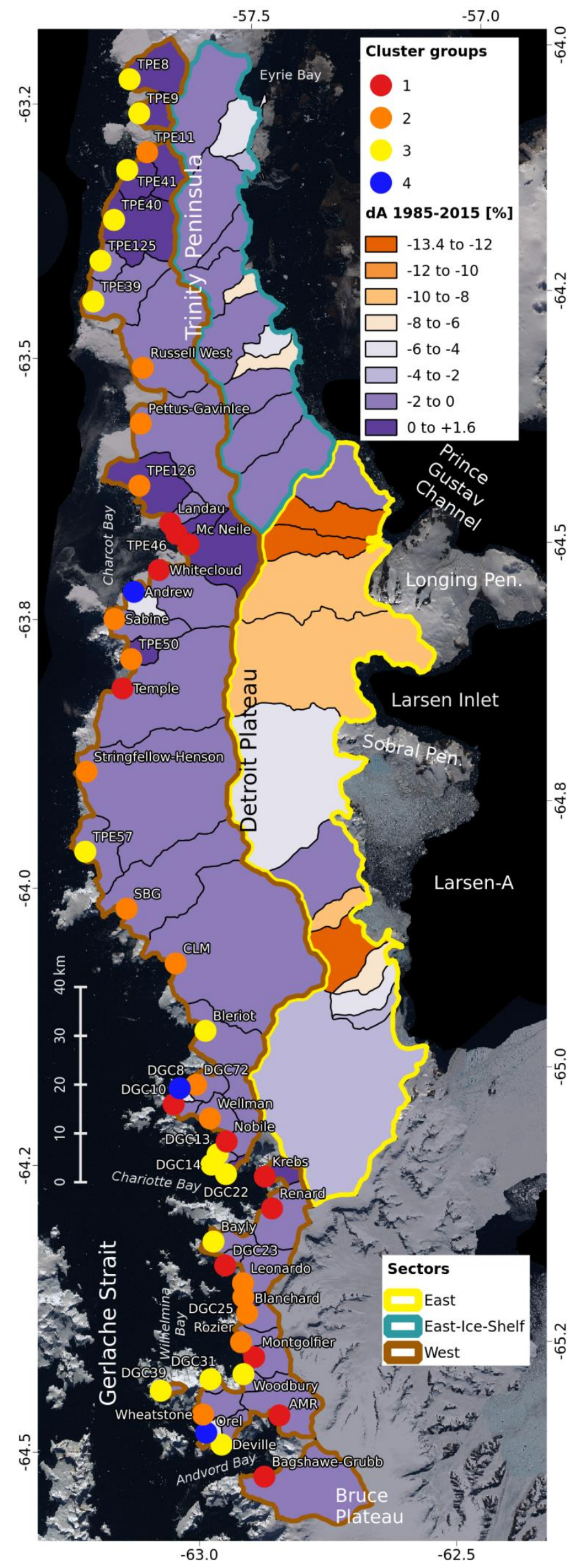

Figure S162. Spatial distribution of glacier types along the west coast (based on velocity measurements at maximum ice thickness at the terminus profiles). Glaciers are group based on a hierarchical cluster analysis (dots). Individual glacier catchment colors: relative area change in the period 1985-2015. Colored polygon outlines: Boundaries of the three sectors. Background: Landsat LIMA Mosaic USGS, NASA, BAS, NSF 
(a)

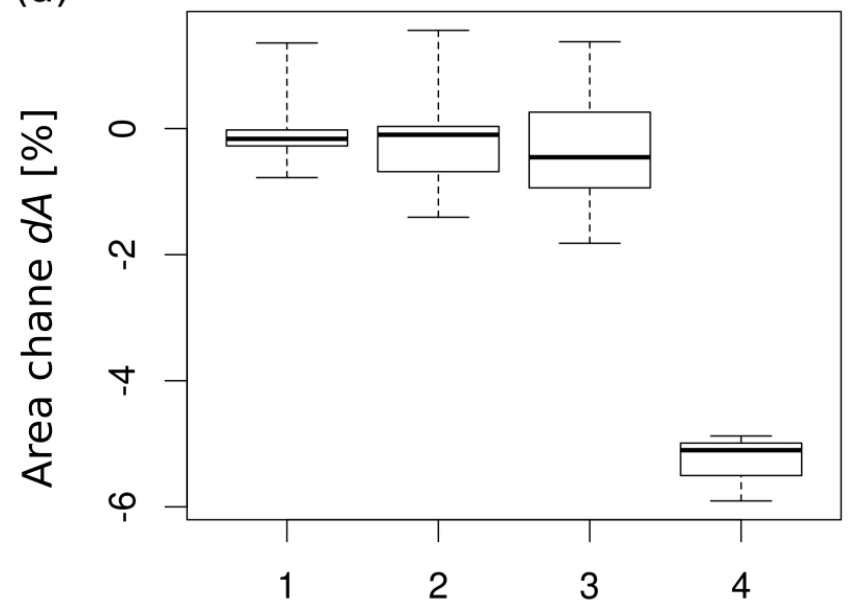

(c)

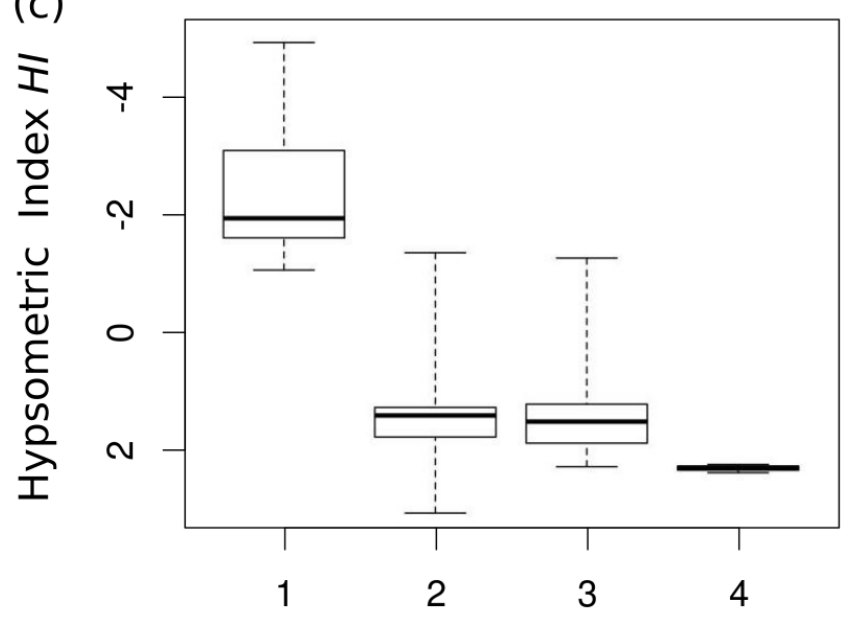

(e)

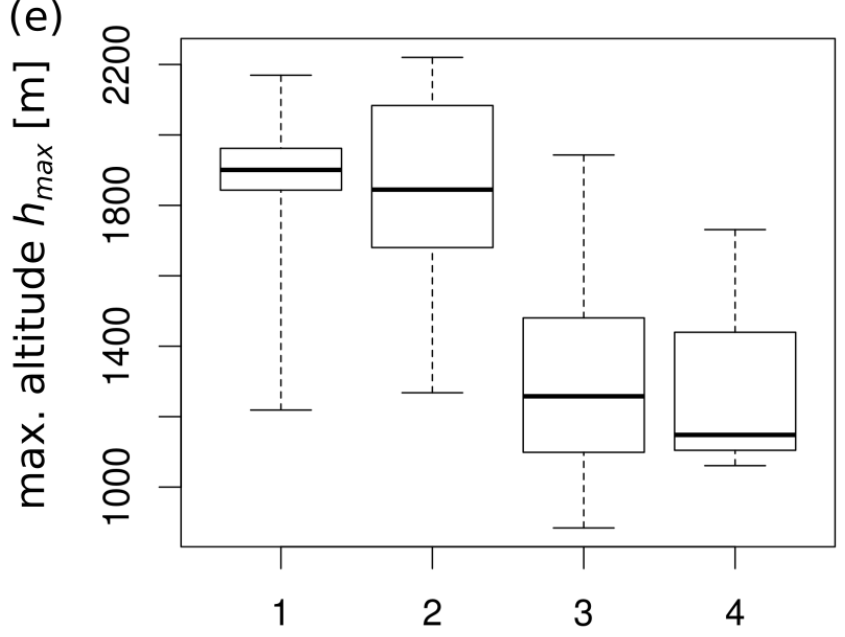

(b)

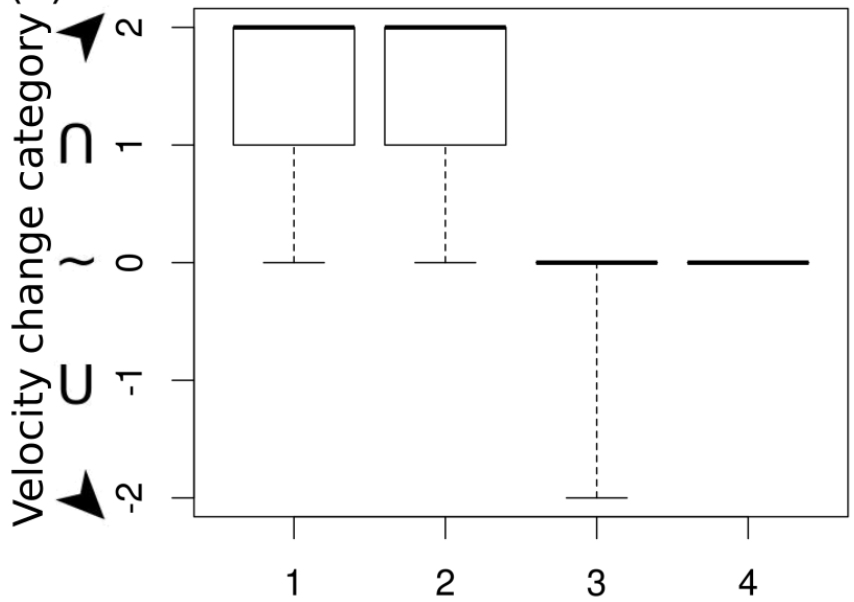

页 $(d)$

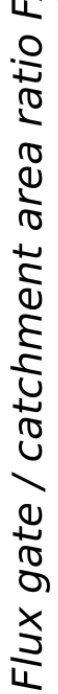

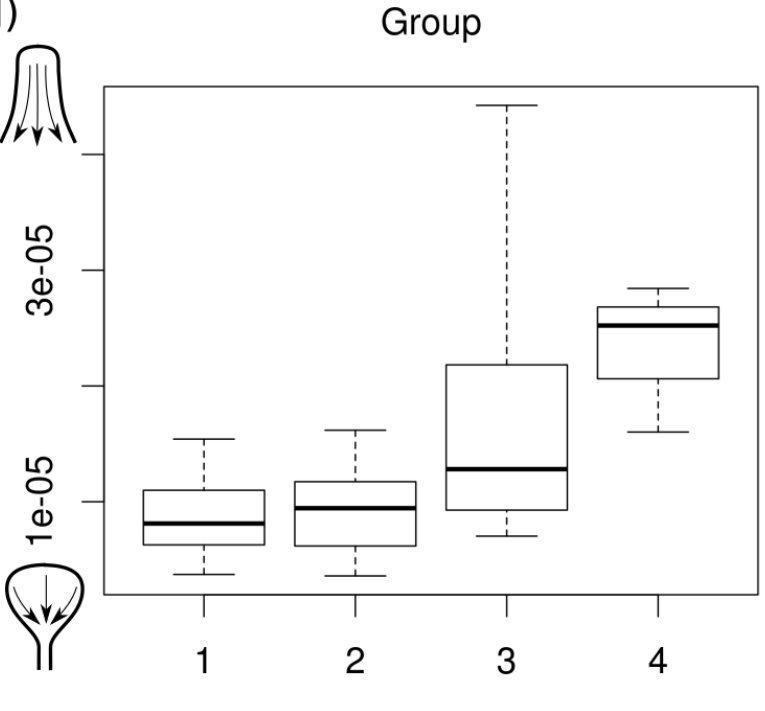

Group

Group

Figure S163. Boxplots of cluster analysis input variables (Sector "West") for each group. Whiskers extend to the most extreme data points. Velocities were measured at maximum ice thickness at the terminus profiles. Panel (b): The symbols used for the velocity change categories (see Table 3) are the same as in Fig. 3. Panel (d): The pictograms illustrate the catchment shape (see Section 3.3). 


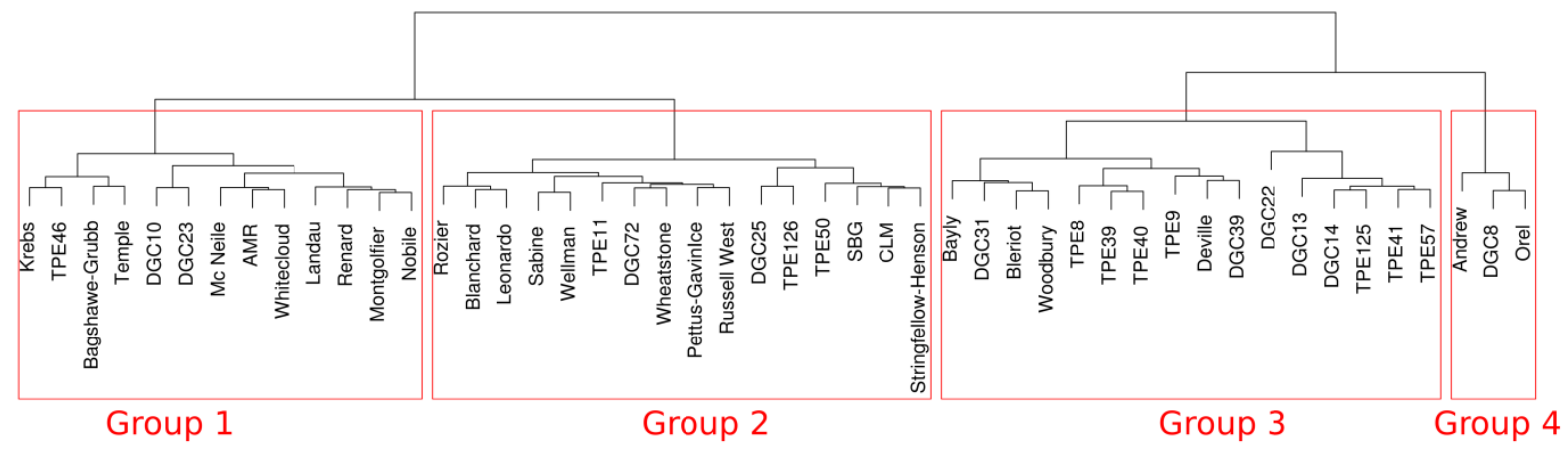

Figure S164. Dendrogram of hierarchical cluster analysis of glaciers in sector "West" coast (based on velocity measurements at maximum ice thickness at the terminus profiles). The glaciers are assorted in four groups (red rectangles). See also Section 5.3. 
Table S1: Observed parameters of the individual glaciers (median velocities measured along terminus profiles). Table continues next page.

\begin{tabular}{|c|c|c|c|c|c|c|c|c|c|c|c|c|c|c|c|c|c|c|c|c|}
\hline Sector & Basin & $\begin{array}{c}l_{f} \\
{[\mathrm{~m}]}\end{array}$ & $\begin{array}{c}A_{1985-1990} \\
{\left[\mathrm{~km}^{2}\right]}\end{array}$ & $\begin{array}{c}A_{2010-2015} \\
{\left[\mathrm{~km}^{2}\right]}\end{array}$ & $\begin{array}{c}d A \\
{\left[\mathrm{~km}^{2}\right]}\end{array}$ & $\begin{array}{c}\text { Area change } \\
\text { category }\end{array}$ & $\begin{array}{c}\text { Date } v_{s} \\
\text { [yyyy-mm-dd] }\end{array}$ & $\begin{array}{c}\text { Date } v_{E} \\
\text { [yyyy-mm-dd] }\end{array}$ & $\begin{array}{c}d t \\
{[\mathrm{a}]}\end{array}$ & $\left.\begin{array}{c}v_{s} \\
{\left[\mathrm{~m} \mathrm{~d}^{-1}\right]}\end{array}\right]$ & {$\left[\begin{array}{c}V_{E-1} \\
{\left[\mathrm{~m}^{-1}\right]}\end{array}\right]$} & $\begin{array}{c}d v \\
{\left[\mathrm{~m} \mathrm{~d}^{-1}\right]}\end{array}$ & $\begin{array}{l}d v \\
{[\%]}\end{array}$ & $n_{v}$ & $\begin{array}{l}\text { Vel. change } \\
\text { category }\end{array}$ & $\begin{array}{c}h_{\max } \\
{[\mathrm{m} \text { a.s.I.] }}\end{array}$ & $H I$ & $\begin{array}{l}\text { Hypsometric } \\
\text { category }\end{array}$ & $F A$ & Group \\
\hline \multirow[t]{13}{*}{ East } & ADD ID: 2707 & 5535 & 28.78 & 26.82 & -1.96 & retreated & $1995-12-18$ & $2013-12-24$ & 18.03 & 0.276 & 0.107 & -0.170 & -61.375 & 31 & decreased & 1278 & 5.14 & very bottom-heavy & 0.0056 & \\
\hline & ADD ID: 2731 & 10955 & 56.92 & 55.85 & -1.06 & retreated & $1995-12-18$ & $2010-12-31$ & 15.05 & 0.358 & 0.093 & -0.265 & -73.985 & 8 & decreased & 1327 & 2.93 & very bottom-heavy & 0.0055 & \\
\hline & Aitkenhead & 6532 & 156.70 & 155.11 & -1.59 & retreated & $1995-12-18$ & 2013-11-04 & $\begin{array}{l}17.89 \\
17.89\end{array}$ & 0.108 & 0.145 & 0.037 & 34.679 & 32 & peak & 1746 & $\begin{array}{l}-1.23 \\
-1.23\end{array}$ & top-heavy & 0.0024 & \\
\hline & Broad Valley & 5948 & 246.73 & 246.08 & -0.64 & retreated & $1995-12-18$ & $2010-10-17$ & 14.84 & 0.310 & 0.353 & 0.043 & 13.815 & 5 & $\begin{array}{l}\text { stable } \\
\text { sta }\end{array}$ & 1118 & -1.02 & equidimensional & 0.0005 & \\
\hline & Diplock & 8916 & 235.30 & 234.14 & -1.16 & retreated & $1995-12-18$ & 2014-03-27 & 18.28 & 0.559 & 0.449 & -0.110 & -19.743 & 27 & trough & 1845 & -1.44 & 10 & 0.0017 & \\
\hline & Eyrie & 6570 & 89.53 & 84.35 & -5.18 & retreated & $1992-12-25$ & $2010-12-31$ & 18.03 & 0.865 & 0.169 & -0.696 & -80.499 & 7 & decreased & 1076 & 2.39 & very bottom-heavy & 0.0035 & \\
\hline & Russell East & 2156 & 93.75 & 93.38 & -0.37 & retreated & $1992-12-25$ & 2013-12-07 & 20.96 & 0.963 & 0.389 & -0.573 & -59.559 & 34 & decreased & 1370 & 1.48 & bottom-heavy & 0.0035 & \\
\hline & TPE10 & 5465 & 225.96 & 225.24 & -0.72 & retreated & $1995-12-20$ & $2010-10-17$ & 14.84 & 0.277 & 0.137 & -0.140 & -50.635 & 4 & peak & 1386 & 1.43 & bottom-heavy & 0.0033 & \\
\hline & TPE130 & 4493 & 40.58 & 38.72 & -1.86 & retreated & $1996-02-29$ & $2013-12-24$ & 17.83 & 0.680 & 0.201 & -0.479 & -70.498 & 33 & peak & 983 & 2.07 & very bottom-heavy & 0.0076 & \\
\hline & TPE31 & 11684 & 52.70 & 48.76 & -3.94 & retreated & $1992-12-25$ & $2014-12-16$ & 21.99 & 1.844 & 0.344 & -1.500 & -81.352 & 25 & decreased & 1490 & 3.50 & very bottom-heavy & 0.0076 & \\
\hline & TPE32 & 4071 & 108.63 & 108.24 & -0.38 & retreated & $1992-12-25$ & 2014-03-27 & 21.27 & 1.549 & 0.755 & -0.794 & -51.271 & 36 & decreased & 1646 & 1.46 & bottom-heavy & 0.0037 & \\
\hline & TPE34 & 2814 & 22.91 & 22.25 & -0.66 & retreated & $1992-12-25$ & $2010-12-31$ & 18.03 & 1.076 & 0.076 & -1.000 & -92.937 & 10 & decreased & 500 & -1.37 & top-heavy & 0.0023 & \\
\hline & Victory & $\begin{array}{l}2014 \\
9975\end{array}$ & 180.30 & 178.75 & -1.55 & retreated & $1994-02-28$ & 2013-12-24 & 19.83 & 0.612 & 0.765 & 0.153 & 25.078 & 25 & trough & 1645 & 2.11 & very bottom-heavy & 0.0041 & \\
\hline \multirow{2}{*}{$\begin{array}{c}\text { Summary } \\
\text { East }\end{array}$} & mean & & & & & & & & 18.22 & 0.729 & 0.306 & -0.423 & -57.983 & & & 1339 & & & & \\
\hline & sum & 85114 & 1538.78 & 1517.71 & -21.07 & & & & & & & & & 277 & & & & & & \\
\hline \multirow[t]{13}{*}{ East-Ice-Shelf } & ADD ID: 2558 & 5890 & 60.2433 & 56.31 & -3.94 & retreated & 1993-01-29 & $2010-12-29$ & 17.93 & 0.435 & 0.353 & -0.082 & -18.758 & 30 & peak & 1840 & 9.08 & very bottom-heavy & 0.0067 & \\
\hline & ADD ID: 2668 & 20996 & 162.324 & 160.93 & -1.39 & retreated & $1996-02-13$ & 2014-12-16 & 18.85 & 0.435 & 0.340 & -0.095 & -21.821 & 23 & peak & 1342 & 2.88 & very bottom-heavy & 0.0041 & \\
\hline & APPE & 31872 & 696.24 & 639.85 & -56.39 & retreated & $1993-01-12$ & 2014-12-16 & $\begin{array}{l}21.94 \\
21.94\end{array}$ & 0.869 & 0.853 & $\begin{array}{l}-0.015 \\
-0.015\end{array}$ & -1.766 & 114 & $\begin{array}{l}\text { fluctuating } \\
\text { flitis }\end{array}$ & 1964 & 1.82 & very bottom-heavy & 0.0003 & \\
\hline & Arron Icefall & 10557 & 152.356 & 131.88 & -20.48 & retreated & $1993-01-12$ & 2011-01-22 & 18.04 & 0.532 & 0.288 & -0.244 & -45.793 & 39 & peak & 1979 & -1.08 & equidimensional & 0.0061 & \\
\hline & Boydell & 1954 & 108.039 & 94.95 & -13.09 & retreated & $1995-12-18$ & $2014-12-16$ & 19.01 & 0.290 & 0.975 & 0.685 & 236.007 & 37 & peak & 1842 & -1.07 & equidimensional & 0.0009 & \\
\hline & DBE & 12140 & 658.91 & 627.24 & -31.67 & retreated & 1993-01-12 & 2014-02-27 & 21.14 & 0.535 & 0.950 & 0.415 & 77.569 & 85 & peak & 2167 & 1.37 & bottom-heavy & 0.0011 & \\
\hline & Drygalski & 14018 & 990.41 & 964.49 & -25.92 & retreated & 1993-01-29 & $2010-12-29$ & 17.93 & 0.951 & 1.641 & 0.219 & 72.572 & 29 & peak & 2043 & 1.60 & very bottom-heavy & 0.0003 & \\
\hline & LAB2 & 4157 & 38.3889 & 37.47 & -0.92 & retreated & $1993-01-29$ & $2010-12-29$ & 17.93 & 0.060 & 0.065 & 0.006 & 9.726 & 17 & peak & 1779 & 3.76 & very bottom-heavy & 0.0046 & \\
\hline & LAB32 & 5534 & 66.3816 & 63.60 & -2.78 & retreated & $1993-01-12$ & $2010-12-29$ & 17.97 & 0.221 & 0.284 & 0.063 & 28.300 & 17 & stable & 1841 & 3.21 & very bottom-heavy & 0.0046 & \\
\hline & Sjögren & 3838 & 329.298 & 300.73 & -28.57 & retreated & $1992-12-25$ & $2014-12-16$ & 21.99 & 0.570 & 0.638 & 0.068 & 11.897 & 36 & peak & 1926 & 1.97 & very bottom-heavy & 0.0014 & \\
\hline & TPE114 & 7310 & 126.385 & 110.61 & -15.78 & retreated & $1996-02-29$ & $2014-12-16$ & 18.81 & 0.098 & 0.190 & 0.092 & 93.627 & 39 & stable & 1759 & 2.96 & very bottom-heavy & 0.0014 & \\
\hline & TPE61 & 2943 & 54.3413 & 49.09 & -5.25 & retreated & $1993-01-12$ & 2011-01-22 & 18.04 & 0.406 & 0.276 & -0.130 & -31.942 & 42 & peak & 1981 & 2.78 & very bottom-heavy & 0.0022 & \\
\hline & TPE62 & 6700 & 211.811 & 209.40 & -2.41 & retreated & $1992-12-25$ & 2011-01-22 & 18.09 & 0.372 & 0.448 & 0.076 & 20.424 & 42 & peak & 2118 & 2.43 & very bottom-heavy & 0.0013 & \\
\hline \multirow{2}{*}{$\begin{array}{c}\text { Summary } \\
\text { East-Ice-Shelf }\end{array}$} & mean & & & & & & & & 19.05 & 0.444 & 0.562 & 0.118 & 26.480 & & & 1891 & & & & \\
\hline & sum & 127909 & 3655.13 & 3446.54 & -208.59 & & & & & & & & & 550 & & & & & & \\
\hline \multirow[t]{26}{*}{ West } & AMR & 7773 & 137.24 & 136.73 & -0.51 & retreated & 1993-02-01 & 2014-08-22 & 21.57 & 0.157 & 0.837 & 0.679 & 431.515 & 21 & increased & 1884 & -3.82 & very top-heavy & 0.0021 & 1 \\
\hline & Andru & 2951 & 47.05 & 44.41 & -2.64 & retreated & $1992-12-25$ & 2014-08-27 & 21.68 & 0.453 & 0.358 & -0.095 & -21.030 & 107 & decreased & 1731 & 1.99 & very bottom-heavy & 0.0057 & 4 \\
\hline & Bagshawe-Grubb & 10720 & 280.43 & 280.17 & -0.26 & stable & 1993-02-01 & $2010-12-22$ & $\begin{array}{l}17.00 \\
17.90\end{array}$ & 0.302 & 0.233 & $\begin{array}{l}-0.069 \\
-0.069\end{array}$ & -22.782 & 14 & stable & 2169 & -2.88 & very top-heavy & 0.0019 & 1 \\
\hline & Bayly & 4149 & 47.89 & 47.32 & -0.57 & retreated & $1993-0$ & $2014-08-22$ & 21.57 & 0.419 & 0.912 & 0.493 & 117.584 & 42 & increased & 1529 & -1.06 & equidimensional & 0.0027 & 2 \\
\hline & Blanchard & 2005 & 38.00 & 37.63 & -0.36 & retreated & $1993-02-01$ & $2014-08-22$ & 21.57 & 0.341 & 1.084 & 0.744 & 218.153 & 30 & increased & 2060 & 1.53 & very bottom-heavy & 0.0025 & 2 \\
\hline & Bleriot & 8527 & 182.20 & 180.69 & -1.50 & retreated & $1993-02-01$ & 2014-04-10 & 21.20 & 0.836 & 0.300 & -0.536 & -64.134 & 25 & decreased & 1943 & 1.28 & bot & 0.0019 & 3 \\
\hline & CLM & 12682 & 809.85 & 809.58 & -0.27 & stable & 1993-02-01 & $2010-12-29$ & $\begin{array}{l}17.92 \\
\end{array}$ & 0.388 & 0.396 & 0.008 & 2.157 & 34 & peak & 2191 & 1.13 & equidimensional & 0.0016 & 2 \\
\hline & Deville & 8699 & 34.99 & 34.79 & -0.20 & $\begin{array}{l}\text { stable } \\
\text { state }\end{array}$ & 1996-02-15 & $2010-12-22$ & 14.86 & 0.364 & 0.127 & -0.237 & -65.116 & 12 & decreased & 1389 & -1.19 & equidimensional & 0.0025 & 3 \\
\hline & DG & 6423 & 23.47 & 23.40 & -0.06 & stable & $1993-02-01$ & 2014-04-10 & 21.20 & 0.116 & 0.580 & 0.465 & 401.477 & 20 & increased & 1219 & -1.10 & equidimensional & 0.0064 & 2 \\
\hline & DC & 1950 & 10.95 & 10.76 & -0.18 & retreated & $1996-02-15$ & 2014-04-10 & 18.16 & 0.285 & 0.205 & -0.081 & -28.256 & 24 & peak & 901 & 1.28 & bottom-heavy & 0.0071 & 3 \\
\hline & DC & 1684 & 5.66 & 5.64 & -0.02 & stable & $1996-02-15$ & 2014-04-10 & 18.16 & 0.096 & 0.113 & 0.018 & 18.626 & 20 & stak & 88 & 1.90 & very bottom-heavy & 0.0109 & 3 \\
\hline & $\mathrm{DC}$ & 2188 & 8.98 & 9.10 & 0.12 & stable & $1996-02-15$ & 2014-04-10 & 18.16 & 0.190 & 0.084 & -0.106 & -55.993 & 24 & stable & 1113 & -1.24 & top-heavy & 0.0148 & 3 \\
\hline & DGC23 & 1868 & 15.92 & 15.91 & 0.00 & stable & 1993-02-01 & 2014-08-22 & 21.57 & 0.414 & 1.025 & 0.611 & 147.314 & 36 & increased & 1379 & -1.33 & top-heavy & 0.0023 & 2 \\
\hline & DGC25 & 2693 & 14.12 & 14.27 & 0.15 & stable & $1993-02-01$ & 2014-08-22 & 21.57 & 0.363 & 0.820 & 0.457 & 125.807 & 37 & increased & 1850 & 1.52 & very bottom-heavy & 0.0028 & 2 \\
\hline & D & 1466 & 13.30 & 13.06 & -0.24 & retreated & $1996-\mathrm{C}$ & $2010-12-11$ & 14.83 & 0.132 & 0.204 & 0.072 & 54.579 & 8 & stable & 1488 & 1.86 & very bottom-heavy & 0.0029 & 2 \\
\hline & DGC39 & 1331 & 15.07 & 14.97 & -0.10 & retreated & $1993-02-01$ & $2010-12-22$ & 17.90 & 0.529 & 0.164 & -0.365 & -69.044 & 8 & decreased & 1472 & 1.02 & equidimensional & 0.0040 & 3 \\
\hline & DGC72 & 4990 & 38.39 & 38. & -0.30 & & $1993-0$ & $2010-12-29$ & 17.92 & 0.359 & 0.6 & 0.3 & 93.651 & 13 & pe & 1706 & 1.17 & equid & 0.0027 & 2 \\
\hline & & 33 & 9.3 & 8. & -0.4 & retr & 1993 & 2014-04-10 & 21.20 & 0.1 & 0.2 & 0. & 36.012 & 32 & sta & 10 & & very bc & 00094 & 4 \\
\hline & & & & & & & & & & & & & & 13 & & & & & & 1 \\
\hline & & & & 33 & -0 . & & & & 18. & $0.0 \quad-1$ & 0.7 & 0.6 & 954 & 48 & & 174 & -1. & & & 1 \\
\hline & Le & 36 & 84. & 83.7 & -0.49 & retreated & $1993-02-01$ & 2014-0 & 21.57 & 0.281 & 1.493 & 1.212 & 431.732 & 24 & increased & 2106 & 1.06 & equidimensional & 0.0009 & 2 \\
\hline & Mc Neile & 2507 & 184.56 & 184.66 & 0.10 & stable & $1995-12-19$ & $2014-08-27$ & 18.70 & 0.207 & 0.699 & 0.492 & 237.738 & 30 & increased & 1882 & -4.58 & very top-heavy & 0.0006 & 1 \\
\hline & Montgolfier & 4486 & 55.20 & 55.06 & -0.13 & stable & $1993-02-01$ & $2014-08-22$ & 21.57 & 0.141 & 1.371 & 1.230 & 872.806 & 21 & increased & 1929 & -1.32 & $\begin{array}{l}\text { top-heavy } \\
\text { top }\end{array}$ & 0.0022 & 1 \\
\hline & Nobile & 2361 & 57.04 & 56.78 & -0.26 & retreated & 1993-02-01 & 2014-04-10 & 21.20 & 0.233 & 0.372 & 0.139 & 59.586 & 13 & peak & 1901 & -1.28 & top-heavy & 0.0018 & 1 \\
\hline & Orel & 5399 & 19.02 & 18.11 & -0.92 & retreated & 1996-02-15 & $2010-12-22$ & 14.86 & 0.229 & 0.172 & -0.057 & -25.010 & 8 & $\begin{array}{l}\text { stable } \\
\text { stan }\end{array}$ & 1148 & 1.95 & very bottom-heavy & 0.0066 & 4 \\
\hline & Pettus-Gavinlce & 3535 & 330.88 & 330.67 & $\begin{array}{l}-0.21 \\
-0.21\end{array}$ & $\begin{array}{l}\text { stable } \\
\text { state }\end{array}$ & $1992-12-25$ & 2014-08-05 & $\begin{array}{l}21.60 \\
21.62\end{array}$ & 0.686 & 0.385 & $\begin{array}{l}-0.031 \\
-0.301\end{array}$ & -43.827 & $\stackrel{\circ}{33}$ & peak & 1846 & 1.24 & bottom-heavy & 0.0030 & 2 \\
\hline
\end{tabular}




\begin{tabular}{|c|c|c|c|c|c|c|c|c|c|c|c|c|c|c|c|c|c|c|c|c|}
\hline Sector & Basin & $\begin{array}{c}I_{f} \\
{[\mathrm{~m}]}\end{array}$ & $\begin{array}{c}A_{1985-1990} \\
{\left[\mathrm{~km}^{2}\right]}\end{array}$ & $\begin{array}{c}A_{2010-2015} \\
{\left[\mathrm{~km}^{2}\right]}\end{array}$ & $\begin{array}{c}d A \\
{\left[\mathrm{~km}^{2}\right]}\end{array}$ & $\begin{array}{c}\text { Area change } \\
\text { category }\end{array}$ & $\begin{array}{c}\text { Date vs } \\
\text { [yyyy-mm-dd] }\end{array}$ & $\begin{array}{c}\text { Date vE } \\
\text { [yyyy-mm-dd] }\end{array}$ & $\begin{array}{l}\mathrm{dt} \\
{[\mathrm{a}]}\end{array}$ & $\begin{array}{c}v S \\
{[m ~ d-1]}\end{array}$ & $\begin{array}{c}\mathrm{VE} \\
{[\mathrm{m} \mathrm{d}-1]}\end{array}$ & $\begin{array}{c}d v \\
{[m ~ d-1]}\end{array}$ & $\begin{array}{l}d v \\
{[\%]}\end{array}$ & $\mathrm{nv}$ & $\begin{array}{l}\text { Vel. change } \\
\text { category }\end{array}$ & $\begin{array}{c}h_{\max } \\
\text { [m a.s.l.] }\end{array}$ & $H I$ & $\begin{array}{l}\text { Hypsometric } \\
\text { category }\end{array}$ & $F A$ & Group \\
\hline & Renard & 5904 & 118.15 & 117.24 & -0.91 & retreated & $1993-02-01$ & $2014-08-22$ & 21.57 & 0.212 & 1.698 & 1.486 & 699.238 & 36 & increased & 2043 & -1.82 & very top-heavy & 0.0011 & 1 \\
\hline & Rozier & 5984 & 35.57 & 35.07 & -0.50 & retreated & $1996-02-15$ & $2014-08-22$ & 18.53 & 0.977 & 0.944 & -0.033 & -3.420 & 38 & peak & 2061 & 2.70 & very bottom-heavy & 0.0036 & 2 \\
\hline & Russell West & 3450 & 329.28 & 328.95 & -0.33 & retreated & $1996-02-29$ & $2014-08-27$ & 18.50 & 1.072 & 1.759 & 0.687 & 64.111 & 16 & increased & 1645 & 1.44 & bottom-heavy & 0.0028 & 2 \\
\hline & Sabine & 1795 & 83.09 & 82.78 & -0.31 & retreated & $1993-02-01$ & 2014-08-27 & 21.58 & 0.239 & 0.348 & 0.109 & 45.520 & 82 & increased & 1843 & 1.21 & bottom-heavy & 0.0070 & 2 \\
\hline & SBG & 10917 & 327.95 & 327.75 & $\begin{array}{l}-0.20 \\
-0.20\end{array}$ & stable & $1993-02-01$ & $2010-12-29$ & $\begin{array}{l}2.00 \\
17.92\end{array}$ & 0.298 & 0.306 & 0.007 & 2.395 & $\begin{array}{l}34 \\
34\end{array}$ & peak & 2220 & 1.08 & equidimensional & 0.0047 & 2 \\
\hline & Stringfellow-Henson & 7775 & 670.38 & 669.74 & -0.64 & retreated & $1993-02-01$ & 2014-02-28 & 21.09 & 1.100 & 1.233 & 0.132 & 12.029 & 22 & fluctuating & 2167 & 1.55 & very bottom-heavy & 0.0026 & 2 \\
\hline & Temple & 12056 & 453.96 & 453.22 & -0.74 & retreated & $1992-12-25$ & 2014-08-11 & 21.64 & 1.544 & 1.516 & -0.028 & -1.821 & 90 & fluctuating & 1962 & -1.06 & equidimensional & 0.0031 & 1 \\
\hline & TPE11 & 1947 & 70.06 & 70.13 & 0.07 & $\begin{array}{l}\text { stable } \\
\text { s }\end{array}$ & $1995-12-20$ & 2013-12-24 & 18.02 & 0.184 & 1.203 & 1.018 & 552.655 & 20 & increased & 1268 & 1.05 & equidimensional & 0.0028 & 2 \\
\hline & TPE125 & 8741 & 40.41 & 40.13 & -0.27 & stable & $1992-12-25$ & 2013-12-24 & 21.01 & 0.415 & 0.260 & -0.155 & -37.319 & 22 & fluctuating & 1104 & 1.82 & very bottom-heavy & 0.0116 & 3 \\
\hline & TPE126 & 16295 & 145.52 & 147.80 & 2.28 & advanced & 1995-12-19 & $2014-08-27$ & 18.70 & 0.287 & 0.306 & 0.019 & 6.542 & 58 & peak & 1655 & 2.20 & very bottom-heavy & 0.0060 & 2 \\
\hline & TPE39 & 9931 & 139.49 & 139.40 & -0.08 & stable & $1995-12-19$ & 2013-12-07 & 17.98 & 0.341 & 0.690 & 0.348 & 102.092 & 21 & peak & 1384 & 1.13 & equidimensional & 0.0051 & 2 \\
\hline & TPE40 & 13405 & 184.11 & 184.69 & 0.58 & stable & $1992-12-25$ & $2013-12-24$ & 21.01 & 0.718 & 0.406 & -0.312 & -43.414 & 27 & decreased & 1386 & 1.01 & equidimensional & 0.0059 & 3 \\
\hline & TPE41 & 9256 & 53.13 & 53.24 & 0.11 & stable & $1995-12-19$ & $2013-12-07$ & 17.98 & 0.326 & 0.281 & -0.046 & -13.987 & 26 & stable & 1094 & 1.98 & very bottom-heavy & 0.0107 & 3 \\
\hline & TPE46 & 2785 & 33.94 & 34.34 & 0.41 & advanced & $1992-12-25$ & 2014-08-27 & 21.68 & 0.935 & 0.881 & -0.054 & -5.756 & 42 & fluctuating & 1843 & -1.86 & very top-heavy & 0.0026 & 1 \\
\hline & TPE50 & 2987 & 31.32 & 31.53 & 0.21 & advanced & $1992-12-25$ & 2014-02-28 & 21.19 & 0.450 & 0.517 & 0.067 & 14.899 & 46 & peak & 1839 & 1.13 & equidimensional & 0.0023 & 2 \\
\hline & $\begin{array}{l}\text { TPE57 } \\
\text { TPE }\end{array}$ & 20111 & 100.43 & 100.34 & -0.10 & $\begin{array}{l}\text { stable } \\
\text { sta }\end{array}$ & 1993-02-01 & 2010-12-29 & 17.92 & 0.317 & 0.230 & -0.087 & -27.382 & $\begin{array}{l}40 \\
29\end{array}$ & peak & 1132 & 1.31 & bottom-heavy & 0.0090 & 3 \\
\hline & $\begin{array}{l}\text { TPE8 } \\
\text { TPE }\end{array}$ & 5582 & 111.74 & $\begin{array}{l}112.24 \\
112.24\end{array}$ & $\begin{array}{l}-0.10 \\
0.49\end{array}$ & advanced & $1996-02-11$ & $2013-12-24$ & $\begin{array}{l}17.92 \\
17.88\end{array}$ & 0.991 & 0.739 & $\begin{array}{l}-0.081 \\
-0.252\end{array}$ & $\begin{array}{l}-25.392 \\
-25.395\end{array}$ & 14 & $\begin{array}{l}\text { peak } \\
\text { trough }\end{array}$ & 1104 & 1.19 & equidimensional & 0.0035 & $\begin{array}{l}3 \\
3\end{array}$ \\
\hline & TPE9 & 3735 & 48.96 & 49.64 & 0.68 & advanced & $1995-12-20$ & 2013-12-24 & 18.02 & 0.377 & 0.150 & -0.227 & -60.233 & 17 & decreased & 1085 & 1.41 & bottom-heavy & 0.0057 & 3 \\
\hline & Wellman & 3449 & 48.67 & 48.48 & -0.19 & stable & $1996-$ & 2014-04-10 & 18.16 & 0.161 & 0.255 & 0.094 & 58.300 & 19 & stable & 1772 & 1.47 & bottom-heavy & 0.0037 & 2 \\
\hline & Wheatstone & 4642 & 52.66 & $\begin{array}{l}40.40 \\
52.18\end{array}$ & -0.48 & retreated & 1993-02-01 & $2010-12-22$ & 17.90 & 0.35 & 0.258 & $\begin{array}{l}-0.097 \\
-0.097\end{array}$ & $\begin{array}{l}-27.262 \\
-0.002\end{array}$ & 11 & & 1569 & 1.21 & bottom-heavy & 0.0029 & 2 \\
\hline & Whitecloud & 3711 & 177.77 & 177.66 & -0.11 & & & & 21.64 & 0.454 & 0.481 & 0.027 & 5.848 & 39 & fluctuating & 19 & -2.94 & very t & 0.0013 & 1 \\
\hline & Woodbury & $\begin{array}{l}1464 \\
1464\end{array}$ & 20.24 & 20.03 & -0.21 & retreated & $1993-02-01$ & 2014-08-11 & 21.54 & 0.155 & 0.239 & 0.084 & 53.784 & 23 & stable & 1862 & 1.02 & equidimensional & 0.0024 & 2 \\
\hline Summary & mean & & & & & & & & 19.58 & 0.428 & 0.605 & 0.177 & 41.334 & & & 1636 & & & & \\
\hline West & sum & 268763 & 5809.33 & 5800.18 & -9.14 & & & & & & & & & 1429 & & & & & & \\
\hline $\begin{array}{l}\text { Summary } \\
\text { all glaciers }\end{array}$ & $\begin{array}{l}\text { mean } \\
\text { sum }\end{array}$ & 481786 & 11003.23 & 10764.42 & -238.81 & & & & 19.25 & 0.484 & 0.545 & 0.061 & 12.646 & 2256 & & 1629 & & & & \\
\hline
\end{tabular}

\section{$I_{f}$ - length of ice front}

$d A$ - change in glacier area between 1985 and 2015*

Date $v_{s}$ - date of first velocity measurement

$d t$ - mean time period of velocity measurements

$v_{E}$ - mean of latest velocity measurements (2010-2014)

$n_{v}$ - sum of velocity measurements in the observation period $(d t)$

$h_{\max }$ - average maximum altitude of individual basins

Hypsometric category - see Table 4
$A$ - glacier area in the respective period*

Area change category - see definition in Section 4.1

Date $v_{E}$ - date of last velocity measurement

$v_{s}$ - mean of earliest velocity measurements (1992-1996)

$d v$ - mean velocity change

Velocity change category - see definition in Table 3

$H I$ - Hypsometric Index of the basin

$F A$ - flux gate to catchment size ratio

Group - classification of glaciers in sector "West" according to the hierarchical cluster analysis in Section 4.4.

*since 1995 for the former Larsen-A and Prince Gustav Ice Shelf tributaries (see Section 5.2) 


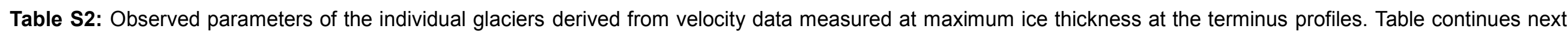
page.

\begin{tabular}{|c|c|c|c|c|c|c|c|c|c|c|c|c|c|}
\hline Sector & Basin & $\begin{array}{c}\text { Date } v_{s} \\
\text { [yyyy-mm-dd] }\end{array}$ & $\begin{array}{c}\text { Date } v_{E} \\
\text { [yyyy-mm-dd] }\end{array}$ & $\begin{array}{l}d t \\
{[a]}\end{array}$ & $\begin{array}{c}v_{S} \\
{\left[\mathrm{~m} \mathrm{~d}^{-1}\right]}\end{array}$ & $\begin{array}{c}v_{E} \\
{\left[\mathrm{~m} \mathrm{~d}^{-1}\right]}\end{array}$ & $\begin{array}{c}d v \\
{\left[\mathrm{~d}^{-1}\right]}\end{array}$ & $\begin{array}{l}d v \\
{[\%]}\end{array}$ & $n_{v}$ & $\begin{array}{l}\text { Vel. change } \\
\text { category }\end{array}$ & $\begin{array}{l}\text { Longitude } \\
{\left[{ }^{\circ}\right]}\end{array}$ & $\begin{array}{l}\text { Latitude } \\
\text { [0] }\end{array}$ & Group \\
\hline \multirow[t]{13}{*}{ East } & ADD ID: 2707 & $1995-11-14$ & $2013-12-24$ & 18.12 & 2.212 & 0.140 & -2.072 & -93.676 & 40 & decreased & -58.3480 & -63.7806 & \\
\hline & ADD ID: 2731 & $1992-12-25$ & $2010-12-31$ & 18.03 & 0.391 & 0.134 & -0.256 & -65.654 & 9 & decreased & -58.1603 & -63.6990 & \\
\hline & Aitkenhead & $1995-12-18$ & $2014-12-16$ & 19.01 & 1.266 & 1.280 & 0.014 & 1.134 & 34 & peak & -58.6712 & -63.9561 & \\
\hline & Broad Valley & $1996-02-11$ & $2010-12-31$ & 14.90 & 0.445 & 0.070 & -0.375 & -84.243 & 3 & decreased & -57.6730 & -63.5434 & \\
\hline & Diplock & $1995-12-18$ & $2014-12-16$ & 19.01 & 0.538 & 0.641 & 0.103 & 19.140 & 52 & trough & -58.7446 & -64.0382 & \\
\hline & Eyrie & $1992-12-25$ & 2010-12-31 & 18.03 & 1.123 & 0.682 & -0.442 & -39.311 & 5 & decreased & -57.7725 & -63.5999 & \\
\hline & Russell East & $1992-12-25$ & 2013-12-24 & 21.01 & 3.127 & 0.552 & -2.575 & -82.350 & 39 & decreased & -58.2950 & -63.7328 & \\
\hline & TPE10 & $1995-11-14$ & $2010-12-31$ & 15.14 & 1.258 & 1.154 & -0.105 & -8.327 & 6 & peak & -58.0911 & -63.6559 & \\
\hline & TPE130 & $1995-11-14$ & 2014-03-27 & 18.38 & 4.998 & 0.273 & -4.725 & -94.540 & 50 & decreased & -58.4762 & -63.8652 & \\
\hline & TPE31 & $1995-12-18$ & 2013-12-24 & 18.03 & 3.986 & 0.169 & -3.816 & -95.756 & 25 & decreased & -58.5084 & -63.9136 & \\
\hline & TPE32 & $1995-12-19$ & $2014-12-16$ & 19.01 & 1.848 & 0.625 & -1.223 & -66.185 & 49 & decreased & -58.5985 & -63.9253 & \\
\hline & TPE34 & $1992-12-25$ & $2010-12-31$ & 18.03 & 1.369 & 0.365 & -1.004 & -73.345 & 6 & decreased & -57.9752 & -63.6675 & \\
\hline & Victory & $1995-11-14$ & $2013-12-02$ & 18.06 & 1.284 & 1.222 & -0.062 & -4.852 & 37 & trough & -58.3952 & -63.8057 & \\
\hline $\begin{array}{c}\text { Summary } \\
\text { East }\end{array}$ & $\begin{array}{l}\text { mean } \\
\text { sum }\end{array}$ & & & 18.06 & 1.834 & 0.562 & $\begin{array}{l}-1.272 \\
\end{array}$ & -69.360 & 355 & & & & \\
\hline \multirow[t]{13}{*}{ East-Ice-Shelf } & ADD ID: 2558 & 1993-01-29 & $2010-12-29$ & 17.93 & 0.332 & 0.297 & -0.035 & -10.600 & 39 & peak & -60.4713 & -64.6331 & \\
\hline & ADD ID: 2668 & $1995-12-19$ & 2014-03-27 & 18.28 & 1.068 & 0.367 & -0.701 & -65.626 & 24 & decreased & -58.7338 & -64.0949 & \\
\hline & APPE & $1992-12-25$ & $2014-12-16$ & 21.99 & 2.276 & 1.230 & -1.046 & -45.972 & 126 & decreased & -59.5048 & -64.3030 & \\
\hline & Arron Icefall & $1993-01-12$ & $2010-12-29$ & 17.97 & 0.479 & 1.298 & 0.819 & 170.781 & 30 & peak & -60.4392 & -64.5916 & \\
\hline & Boydell & $1996-02-13$ & 2014-12-16 & 18.85 & 0.367 & 1.149 & 0.782 & 213.226 & 37 & peak & -59.0689 & -64.1694 & \\
\hline & DBE & $1993-01-29$ & 2014-02-27 & $\begin{array}{l}1.05 \\
21.09\end{array}$ & $\begin{array}{l}.001 \\
1.710\end{array}$ & $\begin{array}{l}1.149 \\
1.392\end{array}$ & $\begin{array}{l}-0.102 \\
-0.318\end{array}$ & -18.603 & 115 & peak & $\begin{array}{l}-59.0009 \\
-59.9281\end{array}$ & $\begin{array}{l}-04.1094 \\
-64.3595\end{array}$ & \\
\hline & Drygalski & $1993-01-29$ & $2010-12-29$ & $\begin{array}{l}2.09 \\
17.93\end{array}$ & 1.610 & $\begin{array}{l}1.392 \\
5.490\end{array}$ & $\begin{array}{l}-0.518 \\
3.879\end{array}$ & $\begin{array}{l}-10.003 \\
240.893\end{array}$ & 22 & peak & $\begin{array}{l}-59.9281 \\
-60.7602\end{array}$ & $\begin{array}{l}-64.0395 \\
-64.7437\end{array}$ & \\
\hline & $\begin{array}{l}\text { Drygab2 } \\
\text { LAB2 }\end{array}$ & $\begin{array}{l}1993-01-29 \\
1993-01-29\end{array}$ & $2010-12-29$ & $\begin{array}{l}17.93 \\
17.93\end{array}$ & 0.053 & $\begin{array}{l}. .490 \\
0.084\end{array}$ & 0.030 & $\begin{array}{l}24.893 \\
56.272\end{array}$ & 23 & $\begin{array}{l}\text { peak } \\
\text { peak }\end{array}$ & $\begin{array}{l}-60.1602 \\
-60.6258\end{array}$ & $\begin{array}{l}-64.7431 \\
-64.6894\end{array}$ & \\
\hline & LAB32 & $1993-01-29$ & $2010-12-29$ & 17.93 & 0.270 & 0.378 & 0.108 & 39.865 & 23 & peak & -60.5046 & -64.6596 & \\
\hline & Sjögren & $1996-02-13$ & $2014-12-16$ & 18.85 & 0.758 & 1.661 & 0.904 & 119.255 & 61 & peak & -59.1731 & -64.2164 & \\
\hline & TPE114 & $1996-02-13$ & $2014-12-16$ & 18.85 & 0.237 & 0.379 & 0.143 & 60.225 & 55 & fluctuating & -58.9343 & -64.1937 & \\
\hline & TPE61 & $1993-01-12$ & $2011-01-22$ & 18.04 & 0.343 & 0.136 & -0.207 & -60.310 & 44 & peak & -60.3090 & -64.5320 & \\
\hline & TPE62 & $1992-12-25$ & $2011-01-22$ & 18.09 & 0.374 & 0.067 & -0.308 & -82.175 & 40 & peak & -60.1646 & -64.5031 & \\
\hline Summary & mean & & & 18.75 & 0.760 & 1.071 & 0.312 & 41.000 & & & & & \\
\hline East-Ice-Shelf & sum & & & & & & & & 639 & & & & \\
\hline \multirow[t]{26}{*}{ West } & AMR & 1993-02-01 & 2014-08-22 & 21.57 & 0.112 & 2.065 & 1.954 & 1750.085 & 18 & $d$ & -62.3704 & -64.8692 & 1 \\
\hline & Andrew & $1992-12-25$ & 2014-08-27 & 21.68 & 0.430 & 0.339 & -0.091 & -21.211 & 112 & $\begin{array}{l}\text { fluctuating } \\
\text { flitis }\end{array}$ & -59.7202 & -63.8728 & 4 \\
\hline & Bagshawe-Grubb & $1996-02-15$ & $2010-11-29$ & 14.80 & 0.211 & 0.163 & -0.048 & -22.789 & 5 & stable & -62.6231 & -64.9147 & 1 \\
\hline & Bayly & 1993-02-01 & $2014-08-22$ & 21.57 & 0.806 & 0.886 & 0.080 & 9.931 & 37 & fluctuating & -61.8628 & -64.6094 & 3 \\
\hline & Blanchard & $1993-02-01$ & $2014-08-22$ & 21.57 & 0.937 & 1.390 & 0.453 & 48.342 & 37 & increased & -62.0656 & -64.7283 & 2 \\
\hline & Bleriot & $1996-02-15$ & 2014-04-10 & 18.16 & 1.375 & 1.267 & -0.107 & -7.793 & 27 & fluctuating & -61.1699 & -64.4075 & 3 \\
\hline & $C$ & $1993-02-01$ & $2010-12-29$ & 17.92 & 0.288 & 0.394 & 0.106 & 36.932 & 24 & peak & -60.9489 & -64.3093 & 2 \\
\hline & Deville & $1996-02-15$ & $2010-12-22$ & 14.86 & 1.386 & 0.259 & -1.127 & -81.322 & 10 & decreased & -62.5725 & -64.8107 & 3 \\
\hline & DGC10 & $1993-02-01$ & 2014-04-10 & 21.20 & 0.232 & 0.774 & 0.542 & 234.115 & 30 & increased & -61.4458 & -64.4220 & 1 \\
\hline & DGC13 & $1996-02-15$ & $2014-04-10$ & 18.16 & 0.354 & 0.457 & 0.102 & 28.864 & 23 & fluctuating & -61.5345 & -64.5383 & 3 \\
\hline & DGC14 & $1996-02-15$ & 2014-04-10 & 18.16 & 0.096 & 0.124 & 0.028 & 28.973 & 29 & stab & -61.5777 & -64.5362 & 3 \\
\hline & DGC22 & $1996-02-15$ & 2014-04-10 & 18.16 & 0.272 & 0.543 & 0.271 & 99.864 & 33 & fluctuating & -61.5535 & -64.5763 & 3 \\
\hline & DGC23 & $1993-02-01$ & $2014-08-22$ & 21.57 & 0.414 & 0.960 & 0.545 & 131.621 & 37 & incre & -61 & -64.6491 & 1 \\
\hline & & & 2014 & 21.57 & 0.096 & 1.049 & 0.9 & 994 & 38 & & & & 2 \\
\hline & DC & $1993-02-01$ & $2010-12-22$ & 17.90 & 0.719 & 0.211 & -0.509 & -70.700 & 7 & 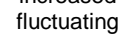 & -62.3808 & -64.7243 & 3 \\
\hline & DGC39 & $1993-02-01$ & $2010-12-22$ & 17.90 & 0.645 & 0.153 & -0.493 & -76.339 & 11 & decreased & -62.5177 & -64.6534 & 3 \\
\hline & DGC72 & $1993-02-01$ & 2014-04-10 & 21.20 & 0.269 & 2.387 & 2.118 & 787.360 & 25 & increased & -61.3022 & -64.4380 & 2 \\
\hline & DGC8 & $1993-02-01$ & 2014-04-10 & 21.20 & 0.169 & 0.384 & 0.215 & 127.060 & 40 & fluctuating & -61.3651 & -64.4162 & 4 \\
\hline & Krebs & $1993-02-01$ & 2014-04-10 & 21.20 & 0.866 & 1.119 & 0.253 & 29.203 & 20 & peak & -61.5201 & -64.6377 & 1 \\
\hline & Land & $1996-02-13$ & $2014-08-27$ & 18.55 & 0.068 & 1.349 & 1.281 & 1876.773 & 43 & increased & -59.3685 & -63.8722 & 1 \\
\hline & $\begin{array}{l}\text { Leona } \\
\text { Leona }\end{array}$ & $1993-02-01$ & $2014-08-22$ & 21.57 & 0.155 & 2.523 & 2.368 & 1525.056 & $\begin{array}{l}45 \\
28\end{array}$ & increased & $\begin{array}{l}-51.0000 \\
-61.9568\end{array}$ & -64.6961 & 2 \\
\hline & & 1995 & $2014-08-27$ & 18.80 & 0.650 & 5.146 & 4.496 & 691.683 & 33 & increased & -59.4035 & -63.9233 & 1 \\
\hline & Mo & 199 & $2014-$ & 21.57 & 0.250 & 2.6 & 2. & 949 & 31 & & & & 1 \\
\hline & & & & 21.20 & & 1.2 & 0.9 & & 18 & & & 22 & 1 \\
\hline & & & & & & & & & 10 & & & & 4 \\
\hline & Pettus-Gavinlce & $1992-12-25$ & 2014-08-05 & 21.62 & 5.651 & 1.951 & -3.700 & -65.473 & 29 & peak & -59.1464 & -63.7450 & 2 \\
\hline
\end{tabular}




\begin{tabular}{|c|c|c|c|c|c|c|c|c|c|c|c|c|c|}
\hline Sector & Basin & $\begin{array}{c}\text { Date vs } \\
\text { [yyyy-mm-dd] }\end{array}$ & $\begin{array}{c}\text { Date vE } \\
\text { [yyyy-mm-dd] }\end{array}$ & $\begin{array}{l}\mathrm{dt} \\
{[\mathrm{a}]}\end{array}$ & $\begin{array}{c}v \mathrm{v} \\
{[\mathrm{m} \mathrm{d}-1]}\end{array}$ & $\begin{array}{c}\mathrm{vE} \\
{[\mathrm{m} \mathrm{d}-1]}\end{array}$ & $\underset{[\mathrm{m} \mathrm{d}-1]}{\mathrm{dv}}$ & $\begin{array}{l}d v \\
{[\%]}\end{array}$ & $\mathrm{nv}$ & $\begin{array}{l}\text { Vel. change } \\
\text { category }\end{array}$ & & & Group \\
\hline & Renard & $1993-02-01$ & $2014-08-22$ & 21.57 & 0.213 & 1.273 & 1.060 & 498.781 & 42 & increased & -61.6438 & -64.6709 & 2 \\
\hline & Rozier & $1996-02-29$ & $2014-08-27$ & 21.57 & 1.777 & 2.210 & 0.433 & 24.342 & 59 & increased & -62.1835 & -64.7457 & 2 \\
\hline & Russell West & $1993-02-01$ & $2014-08-27$ & 18.50 & 0.196 & 0.341 & 0.145 & 73.631 & 105 & increased & -58.8902 & -63.6830 & 2 \\
\hline & Sabine & $1993-02-01$ & $2010-12-12$ & 21.58 & 0.577 & 2.814 & 2.238 & 388.165 & 31 & peak & -59.8056 & -63.8741 & 2 \\
\hline & SBG & $1996-02-13$ & 2011-02-08 & 17.87 & 4.106 & 4.029 & -0.077 & -1.885 & 20 & fluctuating & -60.8223 & -64.1623 & 2 \\
\hline & Stringfellow-Henson & $1992-12-25$ & $2014-02-28$ & 15.00 & $\begin{array}{l}4.106 \\
1.390\end{array}$ & $\begin{array}{l}4.029 \\
1.283\end{array}$ & $\begin{array}{l}-0.106 \\
-0.106\end{array}$ & $\begin{array}{l}-1.885 \\
-7.660\end{array}$ & $\begin{array}{l}20 \\
98\end{array}$ & $\begin{array}{l}\text { Iucuadung } \\
\text { fluctuating }\end{array}$ & $\begin{array}{l}-60.8223 \\
-60.4311\end{array}$ & $\begin{array}{l}-64.1623 \\
-63.9752\end{array}$ & 1 \\
\hline & Temple & $1995-11-14$ & 2013-12-24 & 21.19 & 1.272 & 1.881 & 0.609 & 47.843 & 28 & increased & -60.1247 & -63.9419 & 2 \\
\hline & TPE 1 & $1992-12-25$ & 2013-12-24 & 18.12 & 0.526 & 0.384 & -0.142 & -26.927 & 31 & fluctuating & -58.1397 & -63.4734 & 3 \\
\hline & TPE125 & $1992-12-25$ & 2014-08-27 & 21.01 & 0.150 & 0.277 & 0.127 & 84.605 & 50 & peak & -58.6190 & -63.5057 & 2 \\
\hline & TPE126 & $1995-12-19$ & 2013-12-24 & 21.68 & 1.081 & 0.993 & -0.088 & -8.144 & 25 & fluctuating & -59.3057 & -63.7796 & 3 \\
\hline & TPE39 & $1992-12-25$ & $2013-12-24$ & 18.03 & 0.649 & 0.408 & -0.241 & -37.191 & 25 & fluctuating & -58.7693 & -63.5361 & 3 \\
\hline & TPE40 & $1995-12-19$ & $2013-12-24$ & 21.01 & 0.472 & 0.454 & -0.018 & -3.798 & 17 & fluctuating & -58.3804 & -63.4791 & 3 \\
\hline & TPE41 & $1992-12-25$ & $2014-08-27$ & 18.03 & 1.390 & 1.025 & -0.365 & -26.229 & 47 & fluctuating & -58.2347 & -63.4585 & 1 \\
\hline & TPE46 & $1992-12-25$ & $2014-08-27$ & 21.68 & 1.312 & 0.852 & -0.459 & -35.021 & 113 & fluctuating & -59.3930 & -63.8914 & 2 \\
\hline & TPE50 & $1993-02-01$ & $2010-12-29$ & 21.68 & 0.473 & 0.275 & -0.198 & -41.828 & 22 & stable & $\begin{array}{l}-59.9269 \\
\end{array}$ & -63.9387 & 3 \\
\hline & $\begin{array}{l}\text { TPE57 } \\
\text { TPE }\end{array}$ & $1996-02-11$ & $2013-12-24$ & $\begin{array}{l}17.00 \\
17.92\end{array}$ & 0.671 & 0.692 & 0.021 & $\begin{array}{l}-41.020 \\
3.134\end{array}$ & 12 & fluctuating & $\begin{array}{l}-59.9205 \\
-60.6700\end{array}$ & $\begin{array}{l}-60.9001 \\
-64.0238\end{array}$ & 3 \\
\hline & $\begin{array}{l}\text { TPE8 } \\
\text { TPE }\end{array}$ & $1995-12-19$ & $\begin{array}{l}2013-12-24 \\
2013-24\end{array}$ & $\begin{array}{l}17.92 \\
17.88\end{array}$ & 4.396 & $\begin{array}{l}.692 \\
0.605\end{array}$ & $\begin{array}{r}-3.791 \\
-3.791\end{array}$ & $\begin{array}{c}3.134 \\
-86.236\end{array}$ & $\begin{array}{l}24 \\
24\end{array}$ & decreased & $\begin{array}{l}-60.0100 \\
-57.9284\end{array}$ & $\begin{array}{l}-64.0238 \\
-63.3700\end{array}$ & 3 \\
\hline & TPE9 & $1996-02-15$ & 2014-04-10 & 18.03 & 0.196 & 0.855 & 0.658 & 335.252 & 21 & increased & -58.0371 & -63.4244 & 2 \\
\hline & Wellman & $1993-02-01$ & $2010-12-22$ & 18.16 & 0.455 & 0.530 & 0.075 & 16.501 & 12 & & -61.4298 & -64.4846 & 2 \\
\hline & Wheatstone & $1992-12-25$ & 2014-08-27 & 17.90 & 1.017 & 3.375 & 2.359 & 232.018 & 99 & $\begin{array}{l}\text { increased } \\
\text { inceas }\end{array}$ & -62.5189 & $\begin{array}{l}-64.736402 \\
-64.736\end{array}$ & 1 \\
\hline & Whitecloud & $1993-02-01$ & $2014-08-22$ & 21.68 & 0.153 & 0.237 & 0.085 & 55. & 44 & fluctu & -59.5 & -63.9 & 3 \\
\hline & Woodbury & $1993-02-01$ & 2014-08-22 & 21.57 & 0.213 & 1.273 & 1.060 & 498.781 & 42 & increased & -62.3053 & -64.7749 & 2 \\
\hline Sun & mean & & & 19.65 & 0.831 & 1.200 & 0.369 & 44.461 & & & & & \\
\hline & sum & & & 1921 & 0.994 & 1065 & 0.071 & 7143 & & & & & \\
\hline $\begin{array}{l}\text { all glaciers } \\
\text { aly }\end{array}$ & sum & & & & & & & & 736 & & & & \\
\hline
\end{tabular}

Date $v_{s}$ - date of first velocity measurement

$d t$ - mean time period of velocity measurements

$v_{E}-$ mean of latest velocity measurements (2010-2014)

$n_{v}-$ sum of velocity measurements in the observation period $(d t)$
Date $v_{E}$ - date of last velocity measurement

$v_{s}$ - mean of earliest velocity measurements (1992-1996)

$d v$ - mean velocity change

Velocity change category - see definition in Table 3

Latitude/Longitude - position of velocity measurements (maximum ice thickness at terminus profiles)

Group - classification of glaciers in sector "West" according to the hierarchical cluster analysis in Section 4.4. 
Table S3: Uncertainty $\sigma_{v}$ of intensity tracking results. Table continues next pages.

\begin{tabular}{|c|c|c|c|c|c|c|}
\hline $\begin{array}{c}\text { Date } \\
\text { [yyyy-mm-dd] }\end{array}$ & Satellite & $\begin{array}{l}d t \\
{[d]}\end{array}$ & $\begin{array}{c}\sigma_{v}^{C} \\
{\left[\mathrm{~m} \mathrm{~d}^{-1}\right]}\end{array}$ & $n$ & $\begin{array}{c}\sigma_{v}^{T} \\
{\left[\mathrm{~m} \mathrm{~d}^{-1}\right]}\end{array}$ & $\begin{array}{r}\sigma_{v} \\
{\left[\mathrm{~m} \mathrm{~d}^{-1}\right]}\end{array}$ \\
\hline $1992-12-25$ & ERS & 35 & 0.13 & 9721 & 0.05 & 0.14 \\
\hline $1992-12-25$ & ERS & 35 & 0.25 & 23678 & 0.05 & 0.26 \\
\hline 1993-01-12 & ERS & 70 & 0.07 & 9880 & 0.02 & 0.07 \\
\hline 1993-01-29 & ERS & 35 & 0.10 & 6090 & 0.05 & 0.11 \\
\hline 1993-01-29 & ERS & 35 & 0.23 & 4533 & 0.05 & 0.24 \\
\hline 1993-02-01 & ERS & 35 & 0.20 & 6321 & 0.05 & 0.21 \\
\hline 1994-02-01 & ERS & 21 & 0.35 & 22007 & 0.08 & 0.36 \\
\hline 1994-02-18 & ERS & 54 & 0.07 & 28834 & 0.03 & 0.08 \\
\hline 1994-02-28 & ERS & 33 & 0.16 & 26276 & 0.05 & 0.17 \\
\hline 1995-10-31 & ERS & $1^{*}$ & 0.41 & 150 & 1.60 & 0.41 \\
\hline $1995-11-14$ & ERS & $1^{*}$ & 0.36 & 1961 & 1.60 & 0.36 \\
\hline $1995-11-16$ & ERS & $1^{*}$ & 0.29 & 448 & 1.60 & 0.29 \\
\hline $1995-12-18$ & ERS & 71 & 0.02 & 68711 & 0.02 & 0.03 \\
\hline $1995-12-18$ & ERS & 70 & 0.03 & 77246 & 0.02 & 0.04 \\
\hline $1995-12-19$ & ERS & 71 & 0.02 & 70974 & 0.02 & 0.03 \\
\hline $1995-12-19$ & ERS & 70 & 0.06 & 67287 & 0.02 & 0.06 \\
\hline $1995-12-19$ & ERS & 69 & 0.12 & 66877 & 0.02 & 0.12 \\
\hline $1995-12-20$ & ERS & 70 & 0.04 & 70897 & 0.02 & 0.04 \\
\hline $1995-12-21$ & ERS & 70 & 0.08 & 10755 & 0.02 & 0.08 \\
\hline $1995-12-21$ & ERS & 69 & 0.09 & 9000 & 0.02 & 0.10 \\
\hline 1996-01-22 & ERS & $1^{*}$ & 0.24 & 49973 & 1.60 & 0.24 \\
\hline 1996-01-23 & ERS & $1^{*}$ & 0.34 & 546 & 1.60 & 0.34 \\
\hline 1996-02-11 & ERS & 35 & 0.12 & 10215 & 0.05 & 0.12 \\
\hline $1996-02-11$ & ERS & 35 & 0.14 & 8164 & 0.05 & 0.15 \\
\hline $1996-02-13$ & ERS & 35 & 0.06 & 23882 & 0.05 & 0.08 \\
\hline 1996-02-15 & ERS & 35 & 0.14 & 9379 & 0.05 & 0.15 \\
\hline 1996-02-29 & ERS & 35 & 0.02 & 39573 & 0.05 & 0.05 \\
\hline 1996-03-03 & ERS & 34 & 0.05 & 18324 & 0.05 & 0.07 \\
\hline 1996-03-03 & ERS & 35 & 0.05 & 18395 & 0.05 & 0.07 \\
\hline 1996-03-20 & ERS & $1^{*}$ & 0.30 & 9049 & 1.60 & 0.30 \\
\hline 1997-02-13 & ERS & 35 & 0.04 & 44246 & 0.05 & 0.06 \\
\hline 1997-02-15 & ERS & 35 & 0.11 & 14969 & 0.05 & 0.12 \\
\hline 1997-02-18 & ERS & 35 & 0.09 & 6705 & 0.05 & 0.10 \\
\hline 1998-02-03 & ERS & 35 & 0.07 & 3176 & 0.05 & 0.08 \\
\hline 1999-11-09 & ERS & $1^{*}$ & 0.34 & 4022 & 1.60 & 0.34 \\
\hline 2002-02-07 & ERS & 35 & 0.07 & 9893 & 0.05 & 0.09 \\
\hline $2002-11-29$ & ERS & 35 & 0.13 & 61073 & 0.05 & 0.13 \\
\hline 2002-12-03 & ERS & 35 & 0.13 & 19079 & 0.05 & 0.13 \\
\hline 2002-12-08 & ERS & 35 & 0.29 & 1965 & 0.05 & 0.29 \\
\hline 2002-12-21 & ERS & 70 & 0.05 & 21331 & 0.02 & 0.05 \\
\hline $2002-12-21$ & ERS & 35 & 0.27 & 3396 & 0.05 & 0.27 \\
\hline $2002-12-26$ & ERS & 70 & 0.13 & 2437 & 0.02 & 0.13 \\
\hline 2003-01-07 & ERS & 35 & 0.05 & 24658 & 0.05 & 0.07 \\
\hline 2003-01-08 & ERS & 70 & 0.19 & 4794 & 0.02 & 0.19 \\
\hline 2003-01-12 & ERS & 35 & 0.09 & 2548 & 0.05 & 0.10 \\
\hline 2003-01-25 & ERS & 35 & 0.10 & 14207 & 0.05 & 0.11 \\
\hline 2004-11-01 & ERS & 35 & 0.17 & 30346 & 0.05 & 0.17 \\
\hline 2004-11-17 & ERS & 70 & 0.06 & 71277 & 0.02 & 0.07 \\
\hline 2004-11-19 & ERS & 70 & 0.08 & 32153 & 0.02 & 0.09 \\
\hline 2004-12-06 & ERS & 35 & 0.11 & 33520 & 0.05 & 0.12 \\
\hline $2004-12-24$ & ERS & 70 & 0.11 & 34409 & 0.02 & 0.11 \\
\hline 2004-12-25 & ERS & 35 & 0.14 & 12592 & 0.05 & 0.14 \\
\hline 2005-01-10 & ERS & 35 & 0.28 & 23466 & 0.05 & 0.28 \\
\hline
\end{tabular}




\begin{tabular}{|c|c|c|c|c|c|c|}
\hline $\begin{array}{c}\text { Date } \\
\text { [yyyy-mm-dd] }\end{array}$ & Satellite & $\begin{array}{c}d t \\
{[d]}\end{array}$ & $\begin{array}{c}\sigma_{v}^{C} \\
{\left[\mathrm{~m} \mathrm{~d}^{-1}\right]}\end{array}$ & $n$ & $\begin{array}{c}\sigma_{v}{ }^{\prime} \\
{\left[\mathrm{m} \mathrm{d}^{-1}\right]}\end{array}$ & $\begin{array}{c}\sigma_{v} \\
{\left[\mathrm{~m} \mathrm{~d}^{-1}\right]}\end{array}$ \\
\hline 2006-11-03 & ERS & 35 & 0.19 & 56628 & 0.05 & 0.19 \\
\hline 2006-11-04 & ERS & 35 & 0.14 & 70277 & 0.05 & 0.14 \\
\hline $2008-10-29$ & ERS & 35 & 0.07 & 9881 & 0.05 & 0.08 \\
\hline 2010-02-08 & ERS & 35 & 0.18 & 18041 & 0.05 & 0.19 \\
\hline 2010-02-26 & ERS & 70 & 0.11 & 19172 & 0.02 & 0.11 \\
\hline 2010-03-15 & ERS & 35 & 0.10 & 23486 & 0.05 & 0.11 \\
\hline $2000-09-22$ & R1 & 24 & 0.10 & 20810 & 0.06 & 0.12 \\
\hline 2000-09-22 & R1 & 24 & 0.14 & 33870 & 0.06 & 0.15 \\
\hline 2000-10-01 & $\mathrm{R} 1$ & 24 & 0.06 & 30397 & 0.06 & 0.09 \\
\hline 2006-08-22 & $\mathrm{R} 1$ & 24 & 0.07 & 57259 & 0.06 & 0.10 \\
\hline 2006-08-22 & $\mathrm{R} 1$ & 24 & 0.08 & 21635 & 0.06 & 0.10 \\
\hline $2003-12-22$ & ENVISAT & 35 & 0.31 & 38866 & 0.05 & 0.31 \\
\hline 2004-01-09 & ENVISAT & 70 & 0.03 & 61495 & 0.02 & 0.04 \\
\hline 2004-01-10 & ENVISAT & 35 & 0.13 & 1790 & 0.05 & 0.13 \\
\hline 2004-01-28 & ENVISAT & 70 & 0.16 & 1510 & 0.02 & 0.16 \\
\hline 2004-02-14 & ENVISAT & 35 & 0.09 & 1898 & 0.05 & 0.10 \\
\hline 2004-03-20 & ENVISAT & 35 & 0.13 & 3299 & 0.05 & 0.14 \\
\hline 2004-04-24 & ENVISAT & 35 & 0.12 & 3505 & 0.05 & 0.13 \\
\hline 2004-05-29 & ENVISAT & 35 & 0.10 & 3623 & 0.05 & 0.11 \\
\hline 2004-07-03 & ENVISAT & 35 & 0.10 & 3546 & 0.05 & 0.11 \\
\hline 2004-07-19 & ENVISAT & 35 & 0.03 & 60612 & 0.05 & 0.06 \\
\hline 2004-08-07 & ENVISAT & 35 & 0.11 & 3418 & 0.05 & 0.12 \\
\hline 2004-09-11 & ENVISAT & 35 & 0.14 & 3400 & 0.05 & 0.15 \\
\hline $2004-10-16$ & ENVISAT & 35 & 0.15 & 3449 & 0.05 & 0.16 \\
\hline $2004-12-06$ & ENVISAT & 35 & 0.06 & 63965 & 0.05 & 0.08 \\
\hline $2005-01-28$ & ENVISAT & 70 & 0.02 & 62239 & 0.02 & 0.03 \\
\hline 2005-03-05 & ENVISAT & 35 & 0.15 & 2744 & 0.05 & 0.15 \\
\hline 2005-03-21 & ENVISAT & 35 & 0.19 & 64254 & 0.05 & 0.19 \\
\hline 2005-04-09 & ENVISAT & 35 & 0.13 & 2904 & 0.05 & 0.14 \\
\hline $2005-05-14$ & ENVISAT & 35 & 0.17 & 3016 & 0.05 & 0.17 \\
\hline $2005-06-18$ & ENVISAT & 35 & 0.13 & 3631 & 0.05 & 0.14 \\
\hline $2005-07-23$ & ENVISAT & 35 & 0.14 & 2943 & 0.05 & 0.14 \\
\hline $2005-08-08$ & ENVISAT & 35 & 0.12 & 68061 & 0.05 & 0.13 \\
\hline 2006-02-15 & ENVISAT & 35 & 0.07 & 61205 & 0.05 & 0.08 \\
\hline 2006-03-25 & ENVISAT & 35 & 0.14 & 2755 & 0.05 & 0.15 \\
\hline 2006-07-08 & ENVISAT & 35 & 0.08 & 3488 & 0.05 & 0.09 \\
\hline 2006-08-09 & ENVISAT & 35 & 0.06 & 60954 & 0.05 & 0.08 \\
\hline 2006-08-12 & ENVISAT & 35 & 0.15 & 3302 & 0.05 & 0.15 \\
\hline 2006-09-16 & ENVISAT & 35 & 0.14 & 3295 & 0.05 & 0.15 \\
\hline $2006-10-21$ & ENVISAT & 35 & 0.16 & 2741 & 0.05 & 0.17 \\
\hline 2007-02-18 & ENVISAT & 70 & 0.03 & 71538 & 0.02 & 0.04 \\
\hline 2007-04-29 & ENVISAT & 70 & 0.04 & 65692 & 0.02 & 0.05 \\
\hline 2007-06-20 & ENVISAT & 35 & 0.03 & 63862 & 0.05 & 0.05 \\
\hline 2007-08-12 & ENVISAT & 70 & 0.04 & 61079 & 0.02 & 0.05 \\
\hline 2007-09-01 & ENVISAT & 35 & 0.15 & 3391 & 0.05 & 0.16 \\
\hline 2007-10-03 & ENVISAT & 35 & 0.10 & 61336 & 0.05 & 0.11 \\
\hline $2007-10-06$ & ENVISAT & 35 & 0.16 & 3255 & 0.05 & 0.16 \\
\hline 2008-04-30 & ENVISAT & 35 & 0.10 & 63576 & 0.05 & 0.11 \\
\hline $2008-06-22$ & ENVISAT & 70 & 0.03 & 57922 & 0.02 & 0.04 \\
\hline 2008-08-13 & ENVISAT & 35 & 0.07 & 60539 & 0.05 & 0.08 \\
\hline 2009-03-11 & ENVISAT & 35 & 0.11 & 64638 & 0.05 & 0.12 \\
\hline 2009-07-29 & ENVISAT & 35 & 0.03 & 61130 & 0.05 & 0.05 \\
\hline 2006-06-10 & ALOS & 46 & 0.02 & 15503 & 0.02 & 0.02 \\
\hline $2006-06-17$ & ALOS & 46 & 0.01 & 61958 & 0.02 & 0.02 \\
\hline $2006-06-25$ & ALOS & 46 & 0.08 & 581 & 0.02 & 0.09 \\
\hline 2006-07-14 & ALOS & 46 & 0.02 & 9476 & 0.02 & 0.02 \\
\hline 2006-09-21 & ALOS & 92 & 0.02 & 9912 & 0.01 & 0.02 \\
\hline
\end{tabular}




\begin{tabular}{|c|c|c|c|c|c|c|}
\hline $\begin{array}{c}\text { Date } \\
\text { [yyyy-mm-dd] }\end{array}$ & Satellite & $\begin{array}{c}d t \\
{[d]}\end{array}$ & $\begin{array}{c}\sigma_{v}^{\mathrm{C}} \\
{\left[\mathrm{m} \mathrm{d}^{-1}\right]}\end{array}$ & $n$ & $\begin{array}{c}\sigma_{v}{ }^{\prime} \\
{\left[\mathrm{m} \mathrm{d}^{-1}\right]}\end{array}$ & $\begin{array}{c}\sigma_{v} \\
{\left[\mathrm{~m} \mathrm{~d}^{-1}\right]}\end{array}$ \\
\hline $2006-12-23$ & ALOS & 46 & 0.08 & 5135 & 0.02 & 0.08 \\
\hline 2007-12-04 & ALOS & 46 & 0.03 & 10220 & 0.02 & 0.04 \\
\hline $2007-12-14$ & ALOS & 46 & 0.04 & 2193 & 0.02 & 0.04 \\
\hline 2008-05-14 & ALOS & 46 & 0.01 & 43889 & 0.02 & 0.02 \\
\hline $2008-10-21$ & ALOS & 46 & 0.02 & 10711 & 0.02 & 0.02 \\
\hline 2008-10-31 & ALOS & 46 & 0.13 & 2461 & 0.02 & 0.13 \\
\hline $2008-11-13$ & ALOS & 92 & 0.02 & 10861 & 0.01 & 0.02 \\
\hline 2008-11-14 & ALOS & 46 & 0.02 & 33136 & 0.02 & 0.02 \\
\hline 2008-12-06 & ALOS & 46 & 0.04 & 10213 & 0.02 & 0.04 \\
\hline 2008-12-07 & ALOS & 92 & 0.02 & 36230 & 0.01 & 0.02 \\
\hline $2008-12-16$ & ALOS & 46 & 0.07 & 2291 & 0.02 & 0.07 \\
\hline $2008-12-29$ & ALOS & 92 & 0.02 & 10998 & 0.01 & 0.02 \\
\hline 2008-12-30 & ALOS & 46 & 0.04 & 37661 & 0.02 & 0.04 \\
\hline $2009-01-21$ & ALOS & 46 & 0.02 & 10677 & 0.02 & 0.03 \\
\hline $2009-12-02$ & ALOS & 46 & 0.05 & 3484 & 0.02 & 0.05 \\
\hline 2009-12-09 & ALOS & 46 & 0.03 & 9707 & 0.02 & 0.03 \\
\hline $2009-12-21$ & ALOS & 46 & 0.05 & 2455 & 0.02 & 0.05 \\
\hline $2009-12-26$ & ALOS & 46 & 0.03 & 9385 & 0.02 & 0.03 \\
\hline 2010-01-19 & ALOS & 46 & 0.02 & 15505 & 0.02 & 0.02 \\
\hline 2010-10-08 & ALOS & 46 & 0.04 & 620 & 0.02 & 0.04 \\
\hline $2010-10-17$ & ALOS & 46 & 0.03 & 79294 & 0.02 & 0.03 \\
\hline 2010-11-06 & ALOS & 46 & 0.08 & 2212 & 0.02 & 0.08 \\
\hline $2010-11-08$ & ALOS & 46 & 0.01 & 16076 & 0.02 & 0.02 \\
\hline 2010-11-10 & ALOS & 46 & 0.02 & 422 & 0.02 & 0.03 \\
\hline $2010-11-13$ & ALOS & 46 & 0.04 & 9956 & 0.02 & 0.05 \\
\hline $2010-11-29$ & ALOS & 92 & 0.03 & 2069 & 0.01 & 0.03 \\
\hline 2010-12-01 & ALOS & 92 & 0.01 & 18027 & 0.01 & 0.01 \\
\hline $2010-12-03$ & ALOS & 92 & 0.40 & 426 & 0.01 & 0.40 \\
\hline 2010-12-06 & ALOS & 92 & 0.03 & 10352 & 0.01 & 0.03 \\
\hline $2010-12-11$ & ALOS & 92 & 0.04 & 4683 & 0.01 & 0.04 \\
\hline $2010-12-12$ & ALOS & 46 & 0.03 & 9480 & 0.02 & 0.04 \\
\hline $2010-12-22$ & ALOS & 46 & 0.05 & 1992 & 0.02 & 0.05 \\
\hline $2010-12-26$ & ALOS & 46 & 0.02 & 411 & 0.02 & 0.03 \\
\hline $2010-12-29$ & ALOS & 46 & 0.03 & 10478 & 0.02 & 0.04 \\
\hline 2010-12-31 & ALOS & 46 & 0.01 & 46824 & 0.02 & 0.02 \\
\hline 2011-01-18 & ALOS & 92 & 0.16 & 430 & 0.01 & 0.16 \\
\hline 2011-02-08 & ALOS & 46 & 0.01 & 17569 & 0.02 & 0.02 \\
\hline 2011-02-10 & ALOS & 46 & 0.01 & 394 & 0.02 & 0.02 \\
\hline 2008-10-19 & TSX/TDX & 11 & 0.05 & 4560 & 0.02 & 0.05 \\
\hline $2008-10-25$ & TSX/TDX & 22 & 0.02 & 4362 & 0.01 & 0.02 \\
\hline 2008-10-30 & TSX/TDX & 11 & 0.03 & 4507 & 0.02 & 0.04 \\
\hline 2009-08-01 & TSX/TDX & 11 & 0.02 & 11170 & 0.02 & 0.03 \\
\hline $2009-10-28$ & TSX/TDX & 11 & 0.06 & 4220 & 0.02 & 0.07 \\
\hline $2010-10-26$ & TSX/TDX & 33 & 0.02 & 2678 & 0.01 & 0.02 \\
\hline 2010-11-01 & TSX/TDX & 44 & 0.02 & 3442 & 0.01 & 0.02 \\
\hline $2010-11-17$ & TSX/TDX & 22 & 0.01 & 5995 & 0.01 & 0.01 \\
\hline $2010-11-17$ & TSX/TDX & 11 & 0.06 & 3599 & 0.02 & 0.07 \\
\hline $2010-11-28$ & TSX/TDX & 99 & 0.01 & 3063 & 0.00 & 0.01 \\
\hline $2010-12-15$ & TSX/TDX & 66 & 0.02 & 3476 & 0.00 & 0.02 \\
\hline $2010-12-20$ & TSX/TDX & 77 & 0.01 & 3524 & 0.00 & 0.01 \\
\hline $2010-12-20$ & TSX/TDX & 55 & 0.01 & 4297 & 0.00 & 0.02 \\
\hline $2010-12-26$ & TSX/TDX & 66 & 0.01 & 4341 & 0.00 & 0.01 \\
\hline $2011-01-22$ & TSX/TDX & 11 & 0.02 & 4722 & 0.02 & 0.03 \\
\hline 2011-06-25 & TSX/TDX & 22 & 0.01 & 15556 & 0.01 & 0.02 \\
\hline 2011-06-25 & TSX/TDX & 22 & 0.04 & 9886 & 0.01 & 0.04 \\
\hline 2011-07-06 & TSX/TDX & 44 & 0.04 & 10380 & 0.01 & 0.04 \\
\hline 2011-07-16 & TSX/TDX & 22 & 0.04 & 3582 & 0.01 & 0.04 \\
\hline
\end{tabular}




\begin{tabular}{|c|c|c|c|c|c|c|}
\hline $\begin{array}{c}\text { Date } \\
\text { [yyyy-mm-dd] }\end{array}$ & Satellite & $\begin{array}{l}d t \\
{[d]}\end{array}$ & $\begin{array}{c}\sigma_{v}{ }^{C} \\
{\left[\mathrm{~m} \mathrm{~d}^{-1}\right]}\end{array}$ & $n$ & $\begin{array}{c}\sigma_{v}^{\prime} \\
{\left[\mathrm{m} \mathrm{d}^{-1}\right]}\end{array}$ & $\begin{array}{c}\sigma_{v} \\
{\left[\mathrm{~m} \mathrm{~d}^{-1}\right]}\end{array}$ \\
\hline 2011-07-17 & TSX/TDX & 22 & 0.01 & 15712 & 0.01 & 0.02 \\
\hline 2011-07-16 & TSX/TDX & 22 & 0.10 & 1421 & 0.01 & 0.10 \\
\hline 2011-07-17 & TSX/TDX & 22 & 0.03 & 10450 & 0.01 & 0.03 \\
\hline $2011-07-28$ & TSX/TDX & 44 & 0.02 & 10607 & 0.01 & 0.02 \\
\hline 2011-08-03 & TSX/TDX & 22 & 0.40 & 614 & 0.01 & 0.40 \\
\hline 2011-08-08 & TSX/TDX & 22 & 0.03 & 10394 & 0.01 & 0.04 \\
\hline 2011-08-14 & TSX/TDX & 44 & 0.14 & 1556 & 0.01 & 0.14 \\
\hline 2011-08-19 & TSX/TDX & 44 & 0.03 & 10054 & 0.01 & 0.03 \\
\hline 2011-08-19 & TSX/TDX & 55 & 0.04 & 2385 & 0.00 & 0.04 \\
\hline $2011-08-24$ & TSX/TDX & 22 & 0.03 & 1894 & 0.01 & 0.03 \\
\hline $2011-08-24$ & TSX/TDX & 55 & 0.03 & 10578 & 0.00 & 0.03 \\
\hline 2011-08-29 & TSX/TDX & 33 & 0.03 & 1856 & 0.01 & 0.03 \\
\hline 2011-08-30 & TSX/TDX & 22 & 0.02 & 15605 & 0.01 & 0.02 \\
\hline 2011-08-30 & TSX/TDX & 22 & 0.06 & 7157 & 0.01 & 0.06 \\
\hline 2011-09-04 & TSX/TDX & 33 & 0.01 & 15878 & 0.01 & 0.01 \\
\hline 2011-09-09 & TSX/TDX & 11 & 0.06 & 2325 & 0.02 & 0.06 \\
\hline 2011-09-14 & TSX/TDX & 11 & 0.05 & 3667 & 0.02 & 0.05 \\
\hline $2011-09-14$ & TSX/TDX & 11 & 0.12 & 1279 & 0.02 & 0.12 \\
\hline 2011-09-15 & TSX/TDX & 11 & 0.03 & 15546 & 0.02 & 0.03 \\
\hline 2011-09-15 & TSX/TDX & 11 & 0.07 & 7819 & 0.02 & 0.07 \\
\hline 2011-09-27 & TSX/TDX & 44 & 0.14 & 2001 & 0.01 & 0.14 \\
\hline $2011-10-01$ & TSX/TDX & 33 & 0.02 & 1956 & 0.01 & 0.02 \\
\hline 2011-10-01 & TSX/TDX & 44 & 0.04 & 3582 & 0.01 & 0.04 \\
\hline 2011-10-06 & TSX/TDX & 33 & 0.04 & 3602 & 0.01 & 0.05 \\
\hline 2011-10-06 & TSX/TDX & 33 & 0.11 & 1353 & 0.01 & 0.11 \\
\hline $2011-10-12$ & TSX/TDX & 66 & 0.02 & 3453 & 0.00 & 0.02 \\
\hline $2011-10-17$ & TSX/TDX & 55 & 0.03 & 3541 & 0.00 & 0.03 \\
\hline $2011-10-23$ & TSX/TDX & 11 & 0.06 & 2018 & 0.02 & 0.06 \\
\hline $2011-11-03$ & TSX/TDX & 22 & 0.05 & 3533 & 0.01 & 0.05 \\
\hline $2011-11-03$ & TSX/TDX & 22 & 0.07 & 1209 & 0.01 & 0.07 \\
\hline $2011-11-25$ & TSX/TDX & 22 & 0.03 & 3507 & 0.01 & 0.03 \\
\hline $2011-12-06$ & TSX/TDX & 11 & 0.06 & 2432 & 0.02 & 0.06 \\
\hline $2011-12-12$ & TSX/TDX & 33 & 0.01 & 13467 & 0.01 & 0.01 \\
\hline $2011-12-13$ & TSX/TDX & 44 & 0.05 & 2328 & 0.01 & 0.05 \\
\hline $2011-12-17$ & TSX/TDX & 22 & 0.01 & 4172 & 0.01 & 0.02 \\
\hline $2011-12-18$ & TSX/TDX & 33 & 0.08 & 2365 & 0.01 & 0.08 \\
\hline 2012-01-03 & TSX/TDX & 11 & 0.01 & 16220 & 0.02 & 0.03 \\
\hline 2012-01-03 & TSX/TDX & 11 & 0.07 & 8576 & 0.02 & 0.07 \\
\hline 2012-01-31 & TSX/TDX & 55 & 0.05 & 2338 & 0.00 & 0.05 \\
\hline 2012-03-09 & TSX/TDX & 11 & 0.02 & 13279 & 0.02 & 0.03 \\
\hline 2012-03-09 & TSX/TDX & 11 & 0.16 & 7483 & 0.02 & 0.16 \\
\hline 2012-03-10 & TSX/TDX & 22 & 0.07 & 2343 & 0.01 & 0.07 \\
\hline 2012-03-15 & TSX/TDX & 22 & 0.01 & 15451 & 0.01 & 0.01 \\
\hline 2012-03-15 & TSX/TDX & 33 & 0.05 & 2290 & 0.01 & 0.05 \\
\hline 2012-03-15 & TSX/TDX & 22 & 0.07 & 7142 & 0.01 & 0.07 \\
\hline 2012-03-20 & TSX/TDX & 11 & 0.08 & 6422 & 0.02 & 0.08 \\
\hline 2012-03-21 & TSX/TDX & 44 & 0.05 & 2265 & 0.01 & 0.05 \\
\hline $2012-03-25$ & TSX/TDX & 22 & 0.11 & 1258 & 0.01 & 0.11 \\
\hline 2012-03-26 & TSX/TDX & 55 & 0.05 & 2143 & 0.00 & 0.05 \\
\hline 2012-03-26 & TSX/TDX & 11 & 0.19 & 2259 & 0.02 & 0.19 \\
\hline 2012-04-01 & TSX/TDX & 22 & 0.14 & 2362 & 0.01 & 0.14 \\
\hline 2012-04-06 & TSX/TDX & 33 & 0.06 & 2248 & 0.01 & 0.06 \\
\hline 2012-04-06 & TSX/TDX & 11 & 0.10 & 2316 & 0.02 & 0.10 \\
\hline 2012-04-12 & TSX/TDX & 22 & 0.05 & 2100 & 0.01 & 0.05 \\
\hline $2012-04-17$ & TSX/TDX & 22 & 0.02 & 15486 & 0.01 & 0.02 \\
\hline 2012-04-17 & TSX/TDX & 22 & 0.05 & 7244 & 0.01 & 0.05 \\
\hline $2012-04-30$ & TSX/TDX & 11 & 0.04 & 1747 & 0.02 & 0.05 \\
\hline
\end{tabular}




\begin{tabular}{|c|c|c|c|c|c|c|}
\hline $\begin{array}{c}\text { Date } \\
\text { [yyyy-mm-dd] }\end{array}$ & Satellite & $\begin{array}{l}d t \\
{[d]}\end{array}$ & $\begin{array}{c}\sigma_{v}^{\mathrm{C}} \\
{\left[\mathrm{m} \mathrm{d}^{-1}\right]}\end{array}$ & $n$ & $\begin{array}{c}\sigma_{v}^{T} \\
{\left[\mathrm{~m} \mathrm{~d}^{-1}\right]}\end{array}$ & $\begin{array}{c}\sigma_{v} \\
{\left[\mathrm{~m} \mathrm{~d}^{-1}\right]}\end{array}$ \\
\hline $2012-05-08$ & TSX/TDX & 66 & 0.02 & 3381 & 0.00 & 0.02 \\
\hline 2012-05-09 & TSX/TDX & 22 & 0.02 & 15305 & 0.01 & 0.02 \\
\hline 2012-05-09 & TSX/TDX & 55 & 0.04 & 2344 & 0.00 & 0.04 \\
\hline 2012-05-09 & TSX/TDX & 22 & 0.05 & 6241 & 0.01 & 0.05 \\
\hline $2012-05-13$ & TSX/TDX & 77 & 0.02 & 3656 & 0.00 & 0.02 \\
\hline $2012-05-15$ & TSX/TDX & 44 & 0.04 & 2221 & 0.01 & 0.04 \\
\hline 2012-05-19 & TSX/TDX & 22 & 0.03 & 3672 & 0.01 & 0.03 \\
\hline 2012-05-19 & TSX/TDX & 22 & 0.10 & 1275 & 0.01 & 0.10 \\
\hline 2012-05-20 & TSX/TDX & 55 & 0.04 & 2375 & 0.00 & 0.04 \\
\hline $2012-05-24$ & TSX/TDX & 33 & 0.04 & 1210 & 0.01 & 0.04 \\
\hline 2012-05-30 & TSX/TDX & 33 & 0.03 & 2544 & 0.01 & 0.03 \\
\hline 2012-06-04 & TSX/TDX & 11 & 0.05 & 3532 & 0.02 & 0.06 \\
\hline 2012-06-04 & TSX/TDX & 11 & 0.10 & 1351 & 0.02 & 0.11 \\
\hline 2012-06-05 & TSX/TDX & 33 & 0.01 & 15558 & 0.01 & 0.01 \\
\hline $2012-06-11$ & TSX/TDX & 11 & 0.09 & 2222 & 0.02 & 0.09 \\
\hline 2012-06-15 & TSX/TDX & 11 & 0.08 & 3328 & 0.02 & 0.09 \\
\hline $2012-06-15$ & TSX/TDX & 11 & 0.10 & 1280 & 0.02 & 0.10 \\
\hline $2012-06-21$ & TSX/TDX & 11 & 0.07 & 2621 & 0.02 & 0.07 \\
\hline 2012-06-27 & TSX/TDX & 11 & 0.06 & 7647 & 0.02 & 0.06 \\
\hline 2012-06-28 & TSX/TDX & 44 & 0.04 & 2293 & 0.01 & 0.04 \\
\hline $2012-07-03$ & TSX/TDX & 55 & 0.04 & 2350 & 0.00 & 0.04 \\
\hline 2012-07-03 & TSX/TDX & 33 & 0.05 & 2292 & 0.01 & 0.05 \\
\hline 2012-07-09 & TSX/TDX & 44 & 0.04 & 2389 & 0.01 & 0.04 \\
\hline $2012-07-13$ & TSX/TDX & 33 & 0.03 & 2765 & 0.01 & 0.03 \\
\hline 2012-07-19 & TSX/TDX & 33 & 0.02 & 15662 & 0.01 & 0.02 \\
\hline $2012-07-25$ & TSX/TDX & 11 & 0.09 & 2122 & 0.02 & 0.09 \\
\hline 2012-08-04 & TSX/TDX & 11 & 0.07 & 2545 & 0.02 & 0.07 \\
\hline 2012-08-09 & TSX/TDX & 11 & 0.07 & 3577 & 0.02 & 0.07 \\
\hline 2012-08-09 & TSX/TDX & 11 & 0.12 & 1204 & 0.02 & 0.13 \\
\hline 2012-08-10 & TSX/TDX & 11 & 0.07 & 7151 & 0.02 & 0.07 \\
\hline $2012-08-11$ & TSX/TDX & 44 & 0.08 & 2444 & 0.01 & 0.08 \\
\hline 2012-08-16 & TSX/TDX & 55 & 0.04 & 2374 & 0.00 & 0.04 \\
\hline 2012-08-22 & TSX/TDX & 44 & 0.04 & 2230 & 0.01 & 0.04 \\
\hline 2012-09-07 & TSX/TDX & 11 & 0.14 & 1690 & 0.02 & 0.14 \\
\hline $2012-09-23$ & TSX/TDX & 33 & 0.05 & 1078 & 0.01 & 0.05 \\
\hline 2012-09-29 & TSX/TDX & 55 & 0.04 & 1597 & 0.00 & 0.04 \\
\hline 2012-09-29 & TSX/TDX & 33 & 0.06 & 2397 & 0.01 & 0.06 \\
\hline 2012-10-05 & TSX/TDX & 44 & 0.08 & 2401 & 0.01 & 0.08 \\
\hline $2012-10-10$ & TSX/TDX & 55 & 0.05 & 2372 & 0.00 & 0.05 \\
\hline $2012-10-20$ & TSX/TDX & 33 & 0.03 & 2520 & 0.01 & 0.03 \\
\hline $2012-10-21$ & TSX/TDX & 11 & 0.09 & 2179 & 0.02 & 0.09 \\
\hline $2012-10-27$ & TSX/TDX & 22 & 0.08 & 2296 & 0.01 & 0.08 \\
\hline 2012-11-01 & TSX/TDX & 11 & 0.10 & 2327 & 0.02 & 0.10 \\
\hline 2012-11-01 & TSX/TDX & 33 & 0.17 & 1923 & 0.01 & 0.17 \\
\hline 2012-11-05 & TSX/TDX & 11 & 0.05 & 3446 & 0.02 & 0.05 \\
\hline 2012-11-05 & TSX/TDX & 11 & 0.13 & 1186 & 0.02 & 0.13 \\
\hline $2012-11-07$ & TSX/TDX & 44 & 0.05 & 2312 & 0.01 & 0.05 \\
\hline 2012-11-12 & TSX/TDX & 33 & 0.05 & 2364 & 0.01 & 0.06 \\
\hline 2012-11-12 & TSX/TDX & 11 & 0.12 & 2354 & 0.02 & 0.12 \\
\hline $2012-11-18$ & TSX/TDX & 22 & 0.07 & 2419 & 0.01 & 0.07 \\
\hline $2012-11-23$ & TSX/TDX & 11 & 0.08 & 2204 & 0.02 & 0.09 \\
\hline $2012-12-26$ & TSX/TDX & 55 & 0.03 & 2141 & 0.00 & 0.03 \\
\hline 2013-02-23 & TSX/TDX & 77 & 0.01 & 3503 & 0.00 & 0.01 \\
\hline 2013-03-01 & TSX/TDX & 11 & 0.08 & 2802 & 0.02 & 0.08 \\
\hline 2013-03-17 & TSX/TDX & 11 & 0.06 & 3749 & 0.02 & 0.07 \\
\hline 2013-03-17 & TSX/TDX & 11 & 0.14 & 1255 & 0.02 & 0.14 \\
\hline 2013-03-23 & TSX/TDX & 22 & 0.03 & 3632 & 0.01 & 0.03 \\
\hline
\end{tabular}




\begin{tabular}{|c|c|c|c|c|c|c|}
\hline $\begin{array}{c}\text { Date } \\
\text { [yyyy-mm-dd] }\end{array}$ & Satellite & $\begin{array}{l}d t \\
{[d]}\end{array}$ & $\begin{array}{c}\sigma_{v}^{\mathrm{C}} \\
{\left[\mathrm{m} \mathrm{d}^{-1}\right]}\end{array}$ & $n$ & $\begin{array}{c}\sigma_{v}^{T} \\
{\left[\mathrm{~m} \mathrm{~d}^{-1}\right]}\end{array}$ & $\begin{array}{c}\sigma_{v} \\
{\left[\mathrm{~m} \mathrm{~d}^{-1}\right]}\end{array}$ \\
\hline 2013-03-23 & TSX/TDX & 22 & 0.08 & 1196 & 0.01 & 0.08 \\
\hline 2013-03-26 & TSX/TDX & 11 & 0.08 & 1992 & 0.02 & 0.08 \\
\hline 2013-03-28 & TSX/TDX & 11 & 0.17 & 1347 & 0.02 & 0.18 \\
\hline 2013-03-29 & TSX/TDX & 33 & 0.05 & 1148 & 0.01 & 0.05 \\
\hline 2013-04-03 & TSX/TDX & 33 & 0.09 & 2117 & 0.01 & 0.09 \\
\hline 2013-04-10 & TSX/TDX & 22 & 0.06 & 2172 & 0.01 & 0.07 \\
\hline 2013-04-15 & TSX/TDX & 33 & 0.07 & 2237 & 0.01 & 0.07 \\
\hline 2013-04-26 & TSX/TDX & 55 & 0.05 & 2275 & 0.00 & 0.05 \\
\hline 2013-04-26 & TSX/TDX & 11 & 0.12 & 2379 & 0.02 & 0.13 \\
\hline 2013-04-30 & TSX/TDX & 55 & 0.02 & 3261 & 0.00 & 0.03 \\
\hline 2013-06-08 & TSX/TDX & 22 & 0.03 & 3820 & 0.01 & 0.03 \\
\hline 2013-06-08 & TSX/TDX & 22 & 0.04 & 1021 & 0.01 & 0.04 \\
\hline 2013-06-19 & TSX/TDX & 44 & 0.02 & 3719 & 0.01 & 0.02 \\
\hline 2013-06-30 & TSX/TDX & 22 & 0.03 & 3813 & 0.01 & 0.03 \\
\hline $2013-06-30$ & TSX/TDX & 22 & 0.09 & 1258 & 0.01 & 0.09 \\
\hline 2013-07-28 & TSX/TDX & 33 & 0.01 & 15233 & 0.01 & 0.02 \\
\hline 2013-08-02 & TSX/TDX & 33 & 0.02 & 2763 & 0.01 & 0.02 \\
\hline 2013-08-25 & TSX/TDX & 33 & 0.05 & 2311 & 0.01 & 0.05 \\
\hline 2013-08-30 & TSX/TDX & 33 & 0.01 & 15399 & 0.01 & 0.01 \\
\hline 2013-09-20 & TSX/TDX & 33 & 0.03 & 3602 & 0.01 & 0.03 \\
\hline 2013-09-20 & TSX/TDX & 33 & 0.05 & 1292 & 0.01 & 0.05 \\
\hline 2013-09-27 & TSX/TDX & 33 & 0.04 & 2235 & 0.01 & 0.04 \\
\hline 2013-10-02 & TSX/TDX & 33 & 0.01 & 15262 & 0.01 & 0.01 \\
\hline $2013-10-23$ & TSX/TDX & 33 & 0.02 & 3578 & 0.01 & 0.02 \\
\hline $2013-10-23$ & TSX/TDX & 33 & 0.05 & 1283 & 0.01 & 0.05 \\
\hline 2013-10-30 & TSX/TDX & 33 & 0.05 & 2317 & 0.01 & 0.05 \\
\hline 2013-11-02 & TSX/TDX & 11 & 0.02 & 9090 & 0.02 & 0.03 \\
\hline 2013-11-02 & TSX/TDX & 11 & 0.07 & 484 & 0.02 & 0.07 \\
\hline 2013-11-04 & TSX/TDX & 33 & 0.02 & 15102 & 0.01 & 0.02 \\
\hline 2013-11-09 & TSX/TDX & 11 & 0.05 & 2652 & 0.02 & 0.06 \\
\hline 2013-11-10 & TSX/TDX & 55 & 0.04 & 2294 & 0.00 & 0.04 \\
\hline 2013-11-15 & TSX/TDX & 22 & 0.04 & 2878 & 0.01 & 0.05 \\
\hline 2013-11-20 & TSX/TDX & 22 & 0.03 & 3538 & 0.01 & 0.04 \\
\hline 2013-11-20 & TSX/TDX & 33 & 0.04 & 2955 & 0.01 & 0.04 \\
\hline 2013-11-20 & TSX/TDX & 11 & 0.08 & 2846 & 0.02 & 0.08 \\
\hline 2013-11-20 & TSX/TDX & 22 & 0.10 & 1321 & 0.01 & 0.10 \\
\hline 2013-11-21 & TSX/TDX & 11 & 0.08 & 2180 & 0.02 & 0.08 \\
\hline 2013-11-25 & TSX/TDX & 33 & 0.02 & 3312 & 0.01 & 0.02 \\
\hline 2013-11-25 & TSX/TDX & 33 & 0.05 & 1125 & 0.01 & 0.05 \\
\hline 2013-11-26 & TSX/TDX & 11 & 0.03 & 15060 & 0.02 & 0.03 \\
\hline 2013-11-26 & TSX/TDX & 22 & 0.04 & 2825 & 0.01 & 0.04 \\
\hline $2013-11-26$ & TSX/TDX & 11 & 0.08 & 6708 & 0.02 & 0.09 \\
\hline 2013-11-27 & TSX/TDX & 22 & 0.08 & 2346 & 0.01 & 0.09 \\
\hline 2013-11-30 & TSX/TDX & 44 & 0.00 & 8207 & 0.01 & 0.01 \\
\hline 2013-12-01 & TSX/TDX & 44 & 0.02 & 3438 & 0.01 & 0.02 \\
\hline 2013-12-01 & TSX/TDX & 33 & 0.03 & 2670 & 0.01 & 0.03 \\
\hline 2013-12-01 & TSX/TDX & 11 & 0.06 & 2893 & 0.02 & 0.06 \\
\hline 2013-12-02 & TSX/TDX & 22 & 0.01 & 14680 & 0.01 & 0.01 \\
\hline 2013-12-02 & TSX/TDX & 33 & 0.04 & 2079 & 0.01 & 0.04 \\
\hline 2013-12-02 & TSX/TDX & 22 & 0.06 & 6620 & 0.01 & 0.06 \\
\hline 2013-12-02 & TSX/TDX & 11 & 0.23 & 1957 & 0.02 & 0.24 \\
\hline 2013-12-06 & TSX/TDX & 11 & 0.05 & 3548 & 0.02 & 0.06 \\
\hline $2013-12-06$ & TSX/TDX & 11 & 0.15 & 1322 & 0.02 & 0.15 \\
\hline 2013-12-07 & TSX/TDX & 11 & 0.02 & 14924 & 0.02 & 0.03 \\
\hline 2013-12-07 & TSX/TDX & 22 & 0.04 & 2905 & 0.01 & 0.04 \\
\hline 2013-12-07 & TSX/TDX & 11 & 0.11 & 8347 & 0.02 & 0.11 \\
\hline 2013-12-08 & TSX/TDX & 22 & 0.08 & 2021 & 0.01 & 0.08 \\
\hline
\end{tabular}




\begin{tabular}{|c|c|c|c|c|c|c|}
\hline $\begin{array}{c}\text { Date } \\
\text { [yyyy-mm-dd] }\end{array}$ & Satellite & $\begin{array}{l}d t \\
{[d]}\end{array}$ & $\begin{array}{c}\sigma_{v}^{C} \\
{\left[\mathrm{~m} \mathrm{~d}^{-1}\right]}\end{array}$ & $n$ & $\begin{array}{c}\sigma_{v}^{T} \\
{\left[\mathrm{~m} \mathrm{~d}^{-1}\right]}\end{array}$ & $\begin{array}{c}\sigma_{v} \\
{\left[\mathrm{~m} \mathrm{~d}^{-1}\right]}\end{array}$ \\
\hline 2013-12-12 & TSX/TDX & 22 & 0.03 & 3508 & 0.01 & 0.03 \\
\hline 2013-12-12 & TSX/TDX & 33 & 0.03 & 2814 & 0.01 & 0.03 \\
\hline 2013-12-12 & TSX/TDX & 11 & 0.07 & 3039 & 0.02 & 0.08 \\
\hline 2013-12-12 & TSX/TDX & 22 & 0.09 & 1242 & 0.01 & 0.09 \\
\hline 2013-12-13 & TSX/TDX & 33 & 0.06 & 2306 & 0.01 & 0.06 \\
\hline $2013-12-13$ & TSX/TDX & 11 & 0.07 & 2024 & 0.02 & 0.08 \\
\hline $2013-12-17$ & TSX/TDX & 11 & 0.02 & 3978 & 0.02 & 0.03 \\
\hline 2013-12-17 & TSX/TDX & 33 & 0.03 & 3323 & 0.01 & 0.03 \\
\hline 2013-12-17 & TSX/TDX & 11 & 0.14 & 1290 & 0.02 & 0.14 \\
\hline 2013-12-18 & TSX/TDX & 33 & 0.01 & 13920 & 0.01 & 0.01 \\
\hline 2013-12-18 & TSX/TDX & 22 & 0.03 & 2741 & 0.01 & 0.04 \\
\hline 2013-12-23 & TSX/TDX & 22 & 0.03 & 3725 & 0.01 & 0.03 \\
\hline $2013-12-23$ & TSX/TDX & 11 & 0.05 & 2877 & 0.02 & 0.06 \\
\hline $2013-12-23$ & TSX/TDX & 22 & 0.09 & 1118 & 0.01 & 0.10 \\
\hline $2013-12-24$ & TSX/TDX & 22 & 0.01 & 14893 & 0.01 & 0.01 \\
\hline $2013-12-24$ & TSX/TDX & 22 & 0.05 & 7587 & 0.01 & 0.05 \\
\hline $2013-12-24$ & TSX/TDX & 11 & 0.09 & 2342 & 0.02 & 0.09 \\
\hline 2013-12-28 & TSX/TDX & 11 & 0.05 & 3475 & 0.02 & 0.05 \\
\hline 2013-12-28 & TSX/TDX & 11 & 0.14 & 1096 & 0.02 & 0.15 \\
\hline $2013-12-30$ & TSX/TDX & 44 & 0.03 & 2034 & 0.01 & 0.03 \\
\hline 2014-01-03 & TSX/TDX & 33 & 0.02 & 2819 & 0.01 & 0.02 \\
\hline 2014-01-04 & TSX/TDX & 55 & 0.04 & 2128 & 0.00 & 0.04 \\
\hline 2014-01-04 & TSX/TDX & 33 & 0.05 & 1939 & 0.01 & 0.05 \\
\hline 2014-01-09 & TSX/TDX & 22 & 0.03 & 2828 & 0.01 & 0.03 \\
\hline 2014-01-10 & TSX/TDX & 44 & 0.03 & 2083 & 0.01 & 0.03 \\
\hline 2014-01-10 & TSX/TDX & 22 & 0.10 & 2104 & 0.01 & 0.10 \\
\hline 2014-01-14 & TSX/TDX & 44 & 0.01 & 3685 & 0.01 & 0.01 \\
\hline 2014-01-15 & TSX/TDX & 33 & 0.05 & 2236 & 0.01 & 0.05 \\
\hline 2014-01-19 & TSX/TDX & 33 & 0.02 & 3652 & 0.01 & 0.02 \\
\hline 2014-01-31 & TSX/TDX & 22 & 0.03 & 2647 & 0.01 & 0.03 \\
\hline $2014-02-27$ & TSX/TDX & 44 & 0.03 & 3163 & 0.01 & 0.03 \\
\hline $2014-02-28$ & TSX/TDX & 55 & 0.05 & 2235 & 0.00 & 0.05 \\
\hline 2014-03-24 & TSX/TDX & 11 & 0.08 & 1958 & 0.02 & 0.08 \\
\hline 2014-03-27 & TSX/TDX & 11 & 0.03 & 15610 & 0.02 & 0.03 \\
\hline 2014-04-04 & TSX/TDX & 33 & 0.04 & 1921 & 0.01 & 0.04 \\
\hline 2014-04-10 & TSX/TDX & 22 & 0.05 & 1895 & 0.01 & 0.05 \\
\hline 2014-07-25 & TSX/TDX & 11 & 0.07 & 1184 & 0.02 & 0.08 \\
\hline 2014-08-05 & TSX/TDX & 33 & 0.05 & 1130 & 0.01 & 0.05 \\
\hline 2014-08-06 & TSX/TDX & 22 & 0.03 & 2495 & 0.01 & 0.03 \\
\hline 2014-08-11 & TSX/TDX & 33 & 0.02 & 2649 & 0.01 & 0.02 \\
\hline 2014-08-11 & TSX/TDX & 22 & 0.08 & 1340 & 0.01 & 0.08 \\
\hline 2014-08-22 & TSX/TDX & 11 & 0.08 & 3049 & 0.02 & 0.08 \\
\hline 2014-08-27 & TSX/TDX & 11 & 0.08 & 1215 & 0.02 & 0.09 \\
\hline $2014-12-16$ & TSX/TDX & 11 & 0.03 & 15265 & 0.02 & 0.03 \\
\hline datasets & \multicolumn{2}{|c|}{ Mean values: } & & & & \\
\hline 382 & \multicolumn{2}{|l|}{ All } & 0.07 & 11717 & 0.05 & 0.08 \\
\hline 59 & \multicolumn{2}{|l|}{ ERS } & 0.14 & 26475 & 0.04 & 0.15 \\
\hline 5 & \multicolumn{2}{|l|}{ R1 } & 0.09 & 32794 & 0.06 & 0.11 \\
\hline 41 & \multicolumn{2}{|l|}{ ENVISAT } & 0.11 & 30240 & 0.04 & 0.12 \\
\hline 43 & \multicolumn{2}{|l|}{ ALOS } & 0.05 & 13868 & 0.01 & 0.05 \\
\hline 234 & \multicolumn{2}{|l|}{ TSX/TDX } & 0.06 & 4414 & 0.01 & 0.06 \\
\hline
\end{tabular}

Date - mean date of SAR acquisitions

$d t$ - time interval in days between consecutive SAR acquisitions

$\sigma_{v}{ }^{C}$ - uncertainty of image coregistration

$\sigma_{v}{ }^{T}$ - uncertainty of intensity tracking process

" if $d t=1 \mathrm{~d}->\sigma_{v}=\sigma_{v}{ }^{C}$ see manuscript Section 4.2 